Portland State University

PDXScholar

2-17-1975

\title{
Analysis of the Port of Portland Facility Hinterlands
}

Timothy D. Wilson

Portland State University

Follow this and additional works at: https://pdxscholar.library.pdx.edu/open_access_etds

Part of the Human Geography Commons, and the Physical and Environmental Geography Commons Let us know how access to this document benefits you.

\section{Recommended Citation}

Wilson, Timothy D., "Analysis of the Port of Portland Facility Hinterlands" (1975). Dissertations and Theses. Paper 2524.

https://doi.org/10.15760/etd.2522

This Thesis is brought to you for free and open access. It has been accepted for inclusion in Dissertations and Theses by an authorized administrator of PDXScholar. Please contact us if we can make this document more accessible: pdxscholar@pdx.edu. 
AN ABSTRACT OF THE THESIS OF Timothy D. Wilson for the Master of Science in Geography presented February 17, 1975.

Title: An Analysis of the Port of Portland Facility Hinterlands.

APPROVED BY MEMBERS OF THE THESIS COMMITTEE:

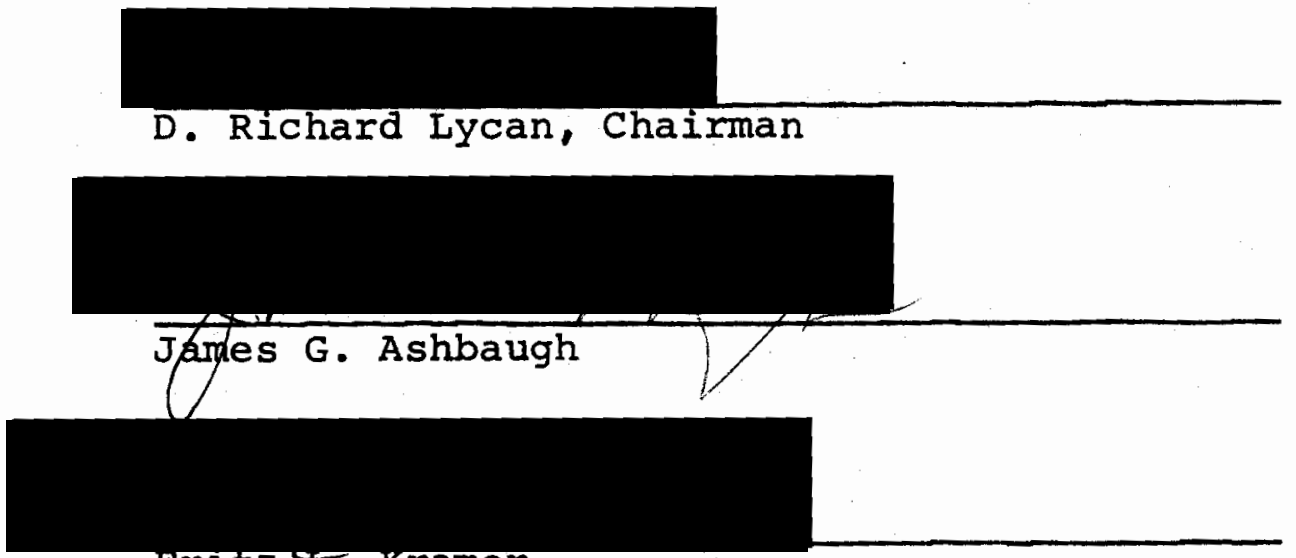

Fritz T. Kramer

Most of the United States port authorities delineate their hinterland by the use of freight rate schedules used by inland carriers. The hinterland is defined as that region having favorable rates to and from a port. The use of freight rate schedules can be applied to a) individual commodities or to b) all the commodities moving through a port. The freight rate method is built on the "rational man" concept. That is, a situation is assumed where there is "perfect knowledge" and a desire to minimize transportation costs. This assumption does not always coincide with reality. 
This paper classifies commodities according to the facilities required to handle them. This is most relevant to port authorities who decide what special facilities may be needed. This classification is also highly relevant to the delineation of port hinterlands. If a port does not provide a given facility for loading and unloading, commodities requiring that type of facility for handing can not move through that port.

The delineation of "facility hinterlands" has two advantages. First, it more closely approximates reality than does the use of freight rates. Second, while it is more time consuming than using freight rates, it does not require expenditures of time and money as large as with the determination of individual commodity hinterlands. Facility hinterland delineation, thus, offers an alternative for port authorities.

The Port of Portland has four main groups of facilities for handling imports and exports: dry bulk, breakbulk, containerized cargo and liquid bulk. In addition, the Port of Portland has special import facilities for steel and automobiles, and special export facilities for grain and logs. The major source of data used to obtain the domestic origins and destinations, by tonnage, for each facility group was the 1973 Export and Import Domestic City Origin and Destination Report Quarterly Reports. 
The origins and destinations are, in most cases, warehousing and distribution points. Therefore, the hinterlands, as identified, are not necessarily ultimate origin and destination hinterlands, but rather they are hinterlands of transshipment points. A port city is a focal point, a gateway, for inbound and outbound cargo. It is expected, therefore, that portland should have a larger warehousing sector in its economy, than cities which are not ports, which handles a great deal of cargo that does not originate in, nor is destined for, Portland.

In an attempt to ascertain the volume, by facility group, of cargo that actually originated in or was destined for Portland, a questionnaire was sent to the exporters and importers who handled cargo originating in or destined for Portland. The questionnaire was sent to all exporters and/or importers who handled 100 tons or more in any given quarter of 1973. The data from the responses to the questionnaires was combined with the original data to delineate the Port of Portland's hinterlands.

Edward Uliman's three-factor typology fits the flow of export goods from domestic origins, through the Port of Portland, to forelgn destinations. Complementarity, transferability, and intervening opportunity, each represent factors making the northwest quadrant of the United States the Port of Portland's export hinterland. 
Oregon, Washington, Idaho, Montana, and Wyoming make up the heart of this hinterland to varying degrees generally correlated to distance. The states bordering the hinterland tend to be less important than those in the hinterland, but more important than states even more distant. The three-factor typology, also, fits the flow of import goods from the Port of Portland to domestic destinations. The three factors combine to place the Port of Portland's import hinterland primarily in oregon and washington. However, complementarity provides a basis for an extended commodity flow in terms of distance and magnitudes for imports. 


\title{
AN ANALYSIS OF THE PORT OF PORTLAND \\ FACIIITY HINTERIANDS
}

\author{
by \\ TIMOTHY D. WILSON
}

A thesis submitted in partial fulfillment of the
requirements for a degree of
MASTER OF SCIENCE
in
GEOGRAPHY

Portland State University

1975 
TO THE OFFICE OF GRADUATE STUDIES AND RESEARCH:

The members of the Committee approve the thesis of Timothy D. Wilson presented February 17, 1975.

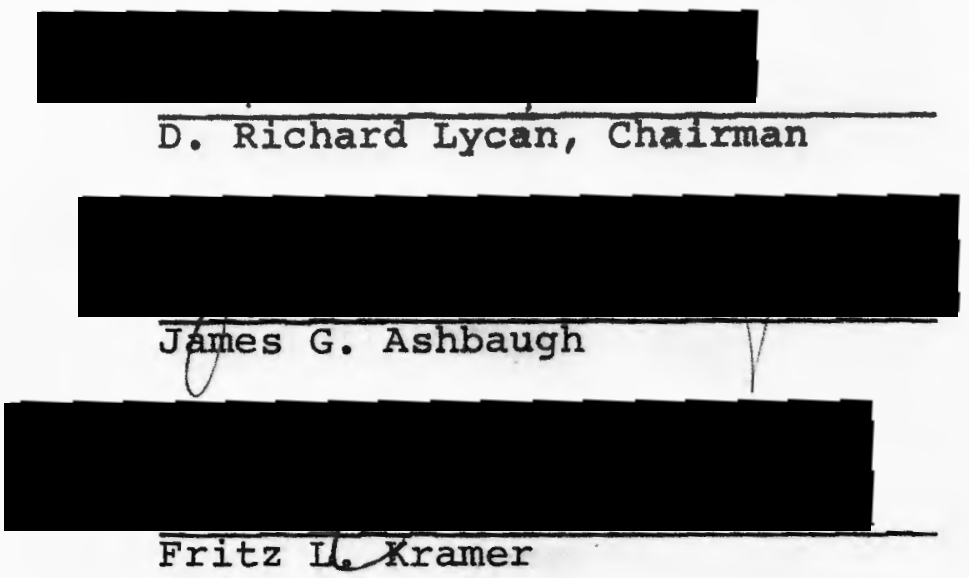

APPROVED:

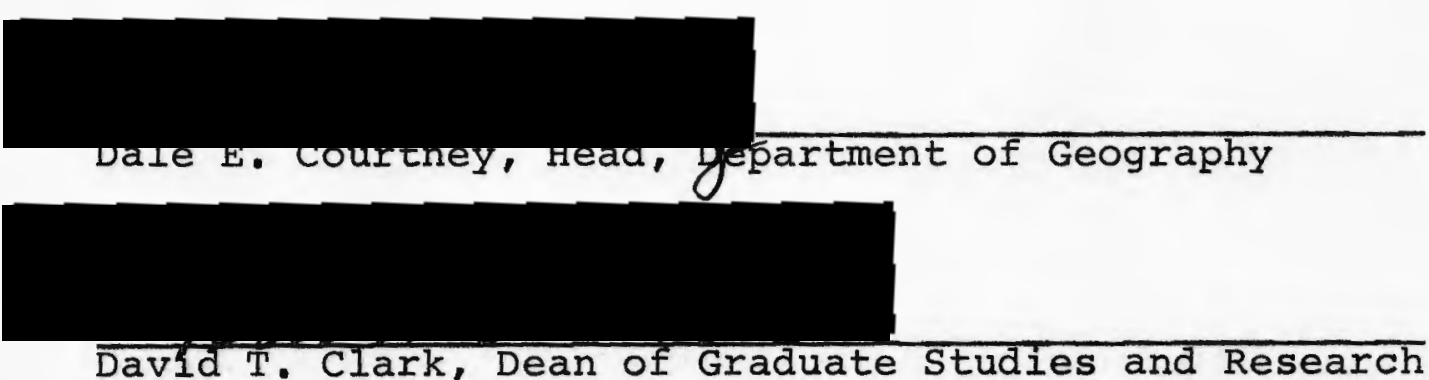

April 4, 1975 


\section{ACKNOWLEDGMENTS}

I wish to thank Dr. D. Richard Lycan, chairman of my thesis committee, as well as the other members of the committee, Dr. Fritz I. Kramer and Dr. James G. Ashbaugh, for their helpful suggestions about various sections of the thesis. I am also grateful to Andy Berkis, Port of Portland Research Manager, as well as the research staff at the Port of Portland who gave their time and help to assist me at "panic moments" in my research. Special thanks go to Mary Brugo for her helpful comments and sympathetic ear. 
TABLE OF CONTENTS

PAGE

ACKNOWLEDGMENTS,$\cdot \cdot \cdot \cdot \cdot \cdot \cdot \cdot \cdot \cdot \cdot \cdot \cdot \cdot \cdot \cdot$, IIST OF TABLES •. . . . . . . . . . . . . vii v vi IIST OF FIGURES . . . . . . . . . . . . . . . xi

\section{CHAPTER}

I INTRODUCTION . . . . . . . . . . 1

II THEORETICAI LOCATION AND INTERACTION THEORY . . . . . . . . . . .

Spatial-Interaction and Location

Processes . . . . . . . . . .

Location Theories ........ 10

Spatial-Interaction Theories . . . . 17

Flow Analysis ... . . . . . 20

III THE PORT OF PORTLAND'S CARGO MOVEMENT

CLASSIFIED INTO FACILITY GROUPS • • • . 28

Exports . . . . . . . . . . 33

Liquid Bulk

Grain

Dry Bulk

Containerized

Logs

Breakbulk 
Imports . . . - . . . . . . .

Bulk

Containerized

steel

Automobiles

Breakbulk

Conclusions . . . . . . . . . . .

Exports

Imports

IV PORTLAND'S VOLUME AS AN ULTIMATE ORIGIN

AND DESTINATION POINT . . . . . . .

Exports

Grain

Dry Bulk

Liquid Bulk

Containerized

Logs

Breakbulk

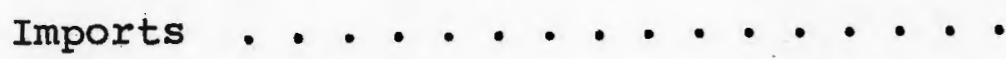

Bulk

Automobiles

Steel

Containerized

Breakbulk

Conclusions . . . . . . . . . .

$V$ THE PORT OF PORTLAND FACILITY

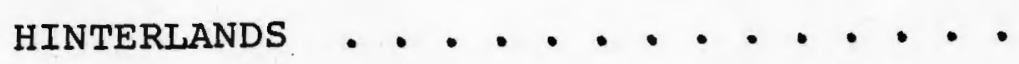

All Facility Groups

Grain

Liquid Bulk

Dry Bulk

Containerized

Breakbulk 
All Facility Groups

Bulk Containerized Automobiles Steel

Breakbulk

Conclusions

A COMMODITIES MOVING THROUGH THE PORT OF PORTLAND, 1973 . . . . . . . 112

B CITY ORIGINS OF EXPORTS FROM PORT OF PORTLAND FACILITIES, 1973 . . . . . 120

C CITY DESTINATIONS OF IMPORTS THROUGH PORT OF PORTLAND FACILITIES, 1973 . . 133

D FIRMS HANDLING I00 TONS OR MORE IN 1973 . . . . . . . . . . . 142

E EXPORT AND IMPORT QUESTIONNAIRES • . . 151

F STATE ORIGINS OF EXPORTS FROM PORT OF PORTIAND FACILITIES, 1973 . . . . 153

G STATE DESTINATIONS OF IMPORTS THROUGH PORT OF PORTLAND FACILITIES, 1973 • • 157 


\section{LIST OF TABLES}

TABLE

PAGE

I 1973 Exports From Port of Portland

Facilities . . . . . . . . . . . .

II The state Origins of 1973 Iiquid Bulk

Exports From Port of Portland

Facilities . . . . . . . . . . . . .

III The State Origins of 1973 Grain Exports

From Port of Portland Facilities . . .

IV The state origins of 1973 Dry Bulk Exports

From Port of Portland Facilities....

$V$ The State Origins of 1973 Containerized

Exports From Port of Portland Facilities 37-38

VI. The State Origins of 1973 Log Exports

From Port of Portland Facilities . . . .

VII The State Origins of 1973 Breakbulk

Exports From Port of Portland

Facilities . . . . . . . . . 40-41

VIII 1973 Imports Through Port of Portland

Facilities . . . . . . . . . . . . .

IX The State Destinations of 1973 Bulk Imports

Through Port of Portland Facilities . . 
X The State Destinations of 1973 Container-

ized Imports Through Port of Portland

Facilities . . . . . . . . . .

XI The State Destinations of 1973 steel

Imports Through Port of Portland

Facilities . . . . . . . . . .

XII The State Destinations of 1973 Automobile

Imports Through Port of Portland

Facilities . . . . . . . . . .

XIII The State Destinations of 1973 Breakbulk

Imports Through Port of Portland

Facilities . . . . . . . . .

XIV Oregon and Portland Origin Percentages

of 1973 Exports From Port of Portland

Facilities . . . . . . . . . .

48

XV Oregon and Portland Destination Percentages

of 1973 Imports Through Port of

Portland Facilities . . . . . . .

XVI Results of Questionnaires Sent to EX-

porters Who Shipped 100 Tons or More

Through Port of Portland Facilities

in 1973 
XVII The state origins of Grain which The

1973 Export and Import Domestic City

Origin and Destination Report In-

dicated As Originating in Portland. .

XVIII The State Origins of Dry Bulk Which the

1973 Export and Import Domestic City

Origin and Destination Report Indicated

As Originating in Portland . . . . 56

XIX The State Origins of Liquid Bulk Which The

1973 Export and Import Domestic City

Origin and Destination Report Indicated

As Originating in Portland ......

$\mathrm{XX}$ The State Origins of containerized Cargo

Which The 1973 Export and Import Domestic

City Origin and Destination Report

Indicated As Originating in Portland .

XXI The State Origins of Breakbulk Cargo Which

The 1973 Export and Import Domestic

City Origin and Destination Report

Indicated as originating in Portland .

60

XXII Results of Questionnaires Sent To Importers who Received 100 Tons or

More Through Port of Portland Facilities 
XXIII The State Destinations of Bulk Cargo

Which The 1973 Export and Import

Domestic City Origin and Destination

Report indicated As Destined for

Portland . . . . . . . . . .

XXIV The State Destinations of Automobiles Which

The 1973 Export and Import Domestic

City Origin and Destination Report

Indicated as Destined for Portland. .

XXV The State Destinations of Steel Which The

1973 Export and Import Domestic City

Origin and Destination Report Indicated

As Destined for portland . . . . .

66

XXVI The State Destinations of Containerized Cargo

Which the 1973 Export and Import Domestic

City origin and Destination Report

Indicated As Destined for Portland. .

XXVII The State Destinations of Breakbulk Cargo

Which the 1973 Export and Import Domestic

City Origin and Destination Report In-

dicated As Destined for Portland. .

XXVIII Firms Responding to Questionnaire As Compared to Firms sent Questionnaires. . 


\section{IIST OF FIGURES}

FIGURE

PAGE

1 Selected Ports of the Pacific Northwest . . . 4

2 Terminal Locations at the port of Portland - 30

3 Origins of Total Exports . . . . . . . 78

4 Origins of Grain Exports . . . . . . . . 79

5 Origins of Liquid Bulk Exports . . . . . . 82

6 Origins of Dry Bulk Exports . . . . . . . 84

7 Origins of Containerized Exports . . . . . 85

8 Origins of Breakbulk Exports . . . . . . . 88

9 Destinations of Total Imports . . . . . . 91

10 Destinations of Bulk Imports . . . . . . . 92

11 Destinations of Automobile Imports . . . . . 94

12 Destinations of Steel Imports . . . . . . . 97

13 Destinations of Containerized Imports . . . 99

14 Destinations of Breakbulk Imports .. . . . 101 


\section{CHAPTER I}

\section{INTRODUCTION}

The purpose of this study is to identify the domestic facility hinterlands of the Port of Portland, Portland, Oregon. Chapter I provides some basic concepts of port and hinterland geography, and a definition of facility hinterlands. Chapter II presents a literature review of some contributions to hinterland research via theoretical location and interaction theory. Chapter III classifies the Port of Portland's cargo movement into facility groups, and identifies the domestic origins of exports and the domestic destinations of imports by those facility groups. The tonnage of cargo indicated in chapter III is further analyzed in Chapter IV based on questionnaires sent to all exporters and importers in Portland who handled 100 tons or more in 1973. This further analysis is necessary to find the amount of cargo that passed through Portland as a transshipment point and did not actually originate in nor was destined for Portland. Chapter $\mathrm{V}$ combines the data from Chapter III and Chapter IV to identify the domestic import and export facility hinterlands of the Port of Portland.

A port's "... primary function is to transfer goods 
(and people) from ocean vessels to land or to inland carriers, and vice versa" (Weigend, p. 570). A port, then, is the place where land and maritime space meet. The relationships between a port and its hinterland are inseparable. "No port structure can be understood when not seen together with its hinterland" (Boerman, p. 6). It follows that a port's hinterland must be delineated and studied to understand that port's trade and development. An understanding of the spatial interrelationships between port and hinterland is necessary for the port administration and commercial interests to attain and maintain a successful port operation. "The port must find ways and means of providing services and facilities that will induce maritime interests and shippers in the hinterland to use it in preference to another port" (Weigend, p. 573). Inducements are necessary because a port is rarely an originator of cargo, rather cargo is generated in the port's hinterland.

Hinterland, as it is used here, is an economically organized and developed land space which is connected with a port by means of transport lines, and which receives or ships goods through that port. Hinterland boundaries are difficult to determine because they vary for different types of commodities, undergo periodic and seasonal variation, and consistently overlap other hinterlands at the periphery. Because of the variable character of hinter- 
lands, "a port does not necessarily have exclusive claim to any part of its hinterland, and an inland area may be the hinterland of several ports" (Weigend, p. 578). It can generally be assumed, however, that the ties of a hinterland with one specific port become closer as the distance from the port decreases.

"Function, export or import, is the most important element in the classification of a hinterland" (Berkis, p. 73). Export and import do not, as used here, refer only to the foreign trade of the country in which the port is located. They refer to commodities arriving at the port, or moving out of the port, by sea regardless of national or international origin or destination.

The study of port geography has developed a theoretical hinterland concept. "The theoretical hinterland concept has three distinct stages: (1) the pure or primary hinterland, (2) the discontinuous hinterland, and (3) the secondary hinterland" (Berkis, p. 66). Regions with a basic internal economic structure and strong geographic controls usually are primary hinterlands. The transportation network in a primary hinterland has its focus on one main outlet for the region, and the region itself is isoIated from any other outlet. A pure or primary hinterland is exemplified by the coastal ports of the Pacific Northwest (see Figure 1l. The commodities that move through ports with primary hinterlands either originate in an area 


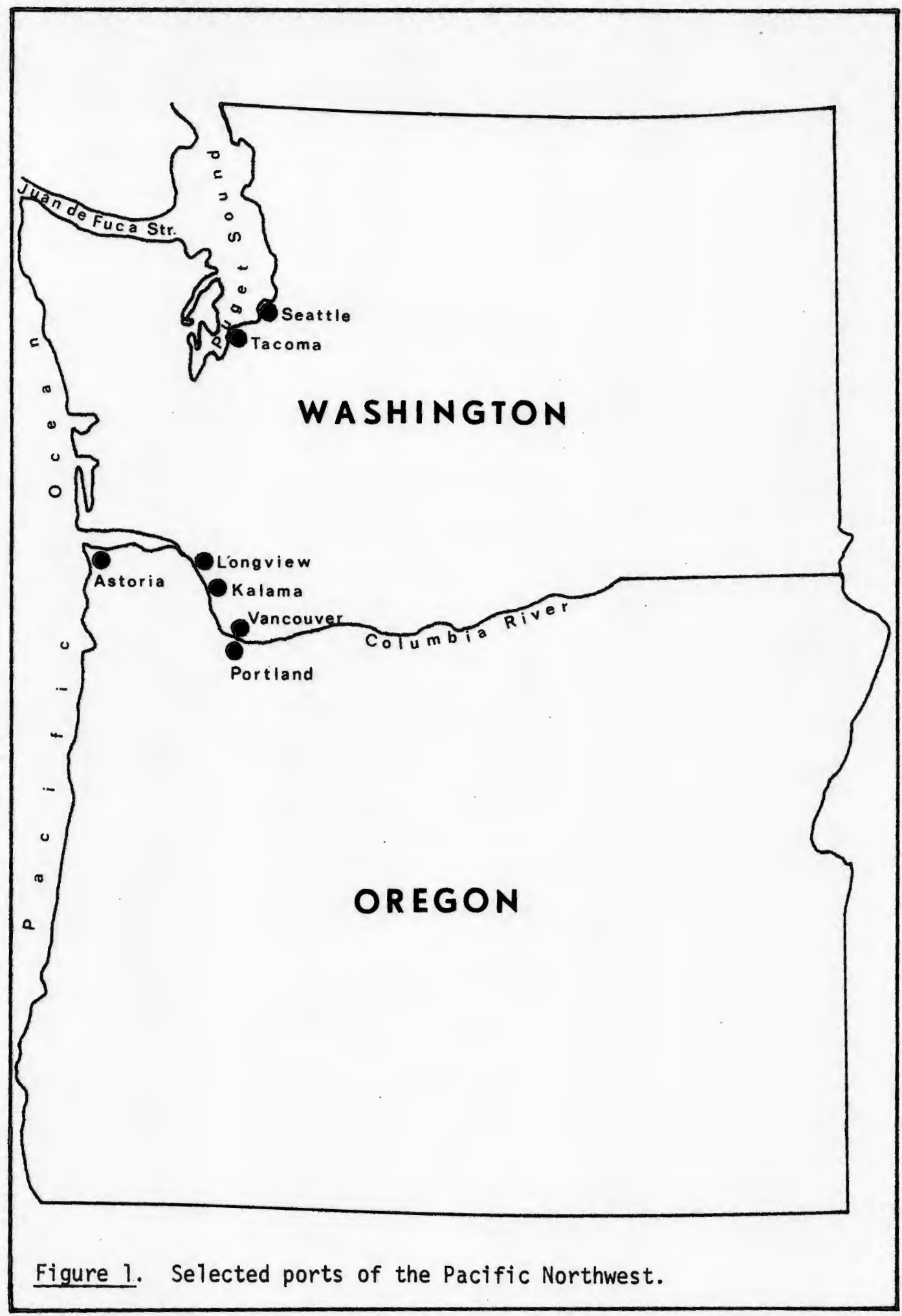


in close proximity to the port facilities, or are destined for a close-in area (close proximity refers to distance in time and money costs).

"Identification of a discontinuous hinterland takes into consideration the fact that some regions are economically closely associated with a primary center, but that the intervening territory has no particular interest for the center" (Van Cleef, p. 309). In a discontinuous hinterland, the producing and consuming areas, each with their own respective primary hinterlands, are separated spatially due to physical features or the lack of a transportation system connecting them together. A Pacific Northwest example of a port with a discontinuous hinterland is Kalama, Washington, located in the lower Columbia River area. "Kalama, because of its trade concentration consisting of grain has only one commodity hinterland which is located in Eastern Washington, Eastern Oregon, Idaho and Montana" (Berkis, p. 69).

The secondary hinterland is the area of overlapping zones of influence in which several ports compete with each other (Morgan, 1958). Exporting and importing areas with equal transportation connections to more than one port constitute secondary hinterlands of those ports. If freight rates are equal to the ports involved, then shipment to or from any of the ports becomes a discretionary choice for the producers in the secondary hinterlands in 
that, as the distance from the port increases, competition with other ports increases. Seattle, Tacoma, Longview and Vancouver, Washington, and Portland, Oregon, are Pacific Northwest ports which have secondary hinterlands because "each of these ports has equal access and rates for any part of the Pacific Northwest region as well as the rest of the United States" (Berkis, p. 71).

A separate hinterland exists for each commodity exported or imported through a port. The commodities that make up the total cargo of a port are usually classified as bulk or general cargo. Bulk cargo moves unpacked in large quantities and can be rapidly transferred from one carrier to another with a minimum of handling if the appropriate machinery is available. General cargo comprises everything that is not carried in bulk and thus encompasses a multitude of commodities, packed or unpacked, which must be handled individually. The division between general cargo and bulk hinterlands is significant to port studies, and to port authorities. Bulk commodities are generally low value goods and cannot stand the value added in transportation, therefore, they will seek the nearest existing port. General cargoes usually are higher in value and are not as sensitive to transportation cost. The general cargo hinterland is, therefore, generally larger than is the bulk cargo hinterland where cost is the major variable. Most of the United States port authorities delineate 
hinterlands by the use of freight rate schedules used by inland carriers. Regions having favorable rates to and from the port are defined as its hinterland. The use of freight rate schedules can be applied to individual commodities or to all the commodities moving through a port in aggregate; the results being many separate hinterlands or one generalized hinterland. This method is built on the "rational man" concept. That is, a situation is assumed where there is "perfect knowledge" and a desire to minimize transportation costs. This assumption does not always coincide with reality.

The separation of all commodities into imports and exports, and even into individual commodities, would result in a more meaningful and complete geographical analysis of port traffic than the use of freight rates. While freight rate hinterland delineation assumes a questionable reality, individual commodity hinterland delineation is costly and time consuming. Most port authorities are unwilling and/or unable to examine individual commodity hinterlands because of the expense involved.

Commodities moving through a port can be classified in any number of ways, i.e., individually, export, import, transport mode used, etc. The classification is a matter of choice based on an author's perception of relevance to his particular study. This paper classifies commodities 
according to the facilities required to handle them. This is most relevant to port authorities who are involved in making decisions that dictate the need (or lack of need) for specific facilities. This classification is also highly relevant to the delineation of port hinterlands. If a port does not provide a given facility for loading and unloading, commodities requiring that type of facility for handling cannot move through that port.

The delineation of "facility hinterlands" has two distinct advantages. First, it more closely approximates reality than does the use of freight rates because of the "perfect knowledge" assumption in the freight rate method. Second, while it is more time consuming than using freight rates in aggregation, it is not as costly and time consuming as investigating individual commodity hinterlands. Facility hinterland delineation, thus, offers a viable alternative for port authorities. The facility hinterland analysis in this paper is for the Port of Portland, Portland, Oregon. The methodology and underlying criteria, however, can be applied by any port authority. 


\section{CHAPTER II}

\section{THEORETICAL LOCATION AND INTERACTION THEORY}

Most hinterland research has involved itself in theoretical location and interaction theory concerning areas of primary production. This chapter is a review of some of the major contributions made in this area of geographic research. The discussion below relates spatial-interaction and location processes to each other, and reviews location theories, spatial-interaction theories and flow analysis.

\section{SPATIAL-INTERACTION AND LOCATION PROCESSES}

Agricultural, industrial and tertiary-activity location processes are inseparable from spatial-interaction processes, or processes relating to a specific class of movement. Any total pattern of spatial interaction, regardless of whether it involves the shipment of commodities or the travel of humans, can be seen as an aggregate expression of individual movements between pairs of origins and destinations. It is this aggregate expression of movements that accounts for production location. The purely economic reasons for production. location are the summation of all individual's perspectives on economies of scale, transport costs and agriculture!'s need for space (Valavanis, p. 69). 
"The motive force which lies behind the determination of production location in agriculture is the same as that which lies behind the equilibrium of all economic forces-namely, the maximization of economic return" (Dunn, p. 266). There are two forms of equilibrium, objective and subjective. The criteria for the former is that equilibrium prices are determined by the condition that the demand for each commodity must equal its supply. Subjective equilibrium requires that all individuals and economic units in the economic society base their maximization of economic return upon equilibrium price. In other words, they regard prices as constant parameters independent of individual influence and production location depends on transport costs. It must be borne in mind that equilibrium is a theoretical concept. Equilibrium conditions in a theoretical system might imply a movement in the direction of equilibrium in reality. "But in a full historic sense, actual economic life never does realize a state of equilibrium" (Isard, 1956, p. ix).

\section{LOCATION THEORIES}

Johann Heinrich von Thünen is considered one of the founders of classical location theory. However, von Thunen's ideas do not constitute location theory. "They amount to a method of analysis which may be applied to any situation in any time or place, and von Thünen himself was 
at pains to make it clear that his particular findings had no claim to universality" (Chisholm, p. 34). The basic assumption underlying von Thünen's analysis is that the areal distribution of crops, livestock and types of farming depends upon competition between products and farming systems for the use of any particular plot of land. Also, "... for every farm there is an optimal combination of land uses, land-use intensities and market outlets, and every farmer is implicitly capable of determining this combination by virtue of his perfect knowledge (information) and ability to reason flawlessly ..." (Pred, 1967, p. 67). Therefore, on any specified piece of land, the enterprise which yields the highest net return will be the use on that land and competing enterprises will be relegated to other plots where they will yield the highest return. Von Thünen's two particular points of concern were "the monetary return over and above the monetary expenses incurred by different types of agriculture" (Chisholm, p. 34), and that such net returns pertain to a unit area of land and not to a unit of product. Von Thünen concluded that since the controlling factor in the determination of land-use is land rent, those enterprises (land uses) which can afford the highest rent will locate closest around the urban area. The next highest use, in rent paying ability, will locate in a second ring outside the first, and so on. Von Thünen related transportation costs to the concentric ring model by 
generalizing "... that products whose transport costs are high relative to value will be produced closest to the market" (Dunn, p. 268). Thus, distance for von Thünen was economic distance, not merely physical distance; economic distance being the cost incurred over a given physical distance and not the mileage distance.

In von Thünen's illustration, there was but one city upon the plain. He did not consider the possibility of unusable land or land particularly suited to a lower order land use. Thus, where von Thünen's rings do exist in reality, they tend to be distorted bands rather than concentric circles (Isard, 1956, p. 276). The distortion is a reflection of the variables mentioned above and the impact of lower transport rates along major transport routes. "In his initial formulation, von Thünen assumed that the cost of transport was proportional to distance" (Chisholm, p. 39). Von Thünen did examine the situation which arises when a more economical transport system is introduced, i.e., navigable river or canal, in later formulations.

Edgar Dunn agrees with von Thünen that the form of land-use which provides the greatest return will make the highest bid for the land and hence displace all others. However, according to Dunn, the land-use closest to the market may not be the highest yielder. Products with a high market price and transport rate might occupy the favored market position even though their yield in terms 
of transport units (pounds, barrels, tons, etc.) was less than some other product. Assuming, then, that transport rates are identical so that transport costs are proportional to weight and volume, it does not follow that the product for which the transport cost form the biggest percentage of value will be located closest to the market. In dealing with hypothetical production units, Dunn concerned himself with maximizing rent and not profits. With this in mind, he formulated the distance-rent function:

$$
R=E(p-a)-E f k
$$

$$
\text { Where } \begin{aligned}
\mathrm{R} & =\text { rent per unit of land } \\
\mathrm{k} & =\text { distance } \\
\mathrm{E} & =\text { yield per unit of land } \\
\mathrm{p}= & \text { market price per unit of commodity } \\
\mathrm{a} & =\text { production cost per unit of commodity } \\
\mathrm{f}= & \text { transport rate per unit of distance of } \\
& \text { each commodity }
\end{aligned}
$$

This formula clearly expresses as a function of distance the additions to total land rent made by each new unit of the land devoted to the cultivation of a single commodity as the distance from the market is increased. The assumptions behind the above formula are threefold. First, it is assumed that perfect mobility and divisibility of all factors other than land is present. Second, the yield per unit of land is assumed to be the same 
everywhere. Third, the assumption is made that the supply of factors is adequate for all production and is available at constant prices. Given the marginal rent function $R=E$ (p-a)-Efk and the assumptions outlined above, "... it becomes plain that the formula describes a linear functional relationship between the two variables, distance and rent" (Dunn, p. 266).

Weber's classical theory of industrial location revolves around transport cost minimization (1929). Manufacture at any other location away from the point of destination will involve an increase in total transportation costs for raw and finished materials. In an attempt to explain reality more closely, Weber also dealt with the idea of weight-losing materials. These are raw materials which experience higher transport costs to the production point than those of the finished product that leaves that point due to weight-loss in manufacture. Raw materials can never bind production to the place where those materials draw industries toward the sources of production. In a situation of a single market and two weight-losing materials located at different points, the place of production will be found within a triangle the lines of which connect the market and the material sources.

August L"osch (1954) and Walter Christaller (1966) also made contributions to location and spatial interaction theories. In Christaller's central place theory, distance 
plays a vital role in the determination of hinterland regions, especially distance measured in time and cost leconomic distance).

Lösch's theory deals with price funnels and crop gradients. The price funnel and crop gradient concept states that the demand for a commodity is a direct function of the price at the production point, and an inverse function of the transport costs required to carry the commodity over space. Industry selling to widely dispersed customers is characterized by price funnels. Conversely, agriculture selling to a city is characterized by crop gradients. Lösch's crop gradients represent the continuous counterpart of von Thünen's rings.

Lösch's market area networks and Christaller's central place theory are based on one major assumption that says consumers procure goods and services from the nearest source (in terms of economic distance) that provides the required good or service. Pred (1967, p. 113) points out two exceptions to this major assumption. First, the consumer may travel to a relatively distant center of the same order if sales-price savings exceed additional transportation costs. This can easily be translated into producers of goods (consumers) seeking service (port facilities) for their goods. Second, the consumer may simultaneously obtain both low and high order goods from a high order center which is more distant than the closest low 
order center. A producer of goods may seek services at a more distant port than the closest one because the former offers a greater variety of service facilities.

Various agricultural, industrial and central place theorists have stated or inferred that economic units behave differently. Most frequently the different behavior has been expressed in one of three categories; sometimes in terms of profit maximization (Lösch), sometimes in terms of cost minimization (Weber), and occasionally in terms of the individual's maximization of his space use (central place theory and journey to consume). It was not until 1922, when Theodor Brinkmann considered both the personal qualities of the agricultural entrepreneur as a factor of [production] intensity and the influence of the farmer's personal qualities upon the location of production (Pred, 1967), that behavioral variables were formally introduced in location theory. All previous and most subsequent location theory, to Brinkmann, involved a fundamental behavioral implication that the location and/or land-use composition of all economic units can best be analyzed theoretically by assuming that the individuals making up the economic units involved act in an unerring and totally rational way. Brinkmann recognized the possibility (or probability) of judgement errors by the individuals and the unlikeliness of any individual having perfect knowledge. 


\section{SPATIAL-INTERACTION THEORIES}

The gravity model, or so-called interactance hypothesis, used by geographers to explain spatial interaction, does not totally achieve this goal. The premise of the basic gravity model maintains that spatial interaction of any kind between pairs of places or points is a positive function of their populations (mass) and inversely proportionate to intervening distance between the pairs. This is expressed symbolically below:

$$
I_{i j}=\frac{P_{i} P_{j}}{D_{i j}}
$$

Where $I i j=$ the interaction between place $i$ and place $j$ $\mathrm{Pi}$ = the population (mass) at place $i$ $P j=$ the population (mass) at place $j$ $D i j=$ the distance between place $i$ and place $j$

The major fault in the basic gravity model is that it does not admit that places can be (and most often are) influenced simultaneously by more than one other point in an interacting system. The potential model is an expansion of the basic gravity model as it allows the estimation of interaction among a set of places. However, to use a potential model in port hinterland analysis would require data for all ports included in the analysis. Another model of spatial interaction was proposed by E.I. Ullman. In his classic description of an intranation commodity flow, UlIman (1957) attempted to delineate 
the pattern of spatial connections in the American economy. Ul Iman believed "... that he had found a logical response to geography and distance, from which he postulated his three-factor typology of spatial interaction: complementarity, intervening opportunity, and transferability" (Smith, p. 130). Areal differentiation is the cause of interaction or circulation, but differentiation itself does not produce interchange. There are many areas in the world that have no connection with each other. Ullman felt that in order for two areas to interact, there must be a demand in one and supply in the other (complementarity). However, complementarity generates interaction between two areas only if no intervening source of supply is available. Transferability, or distance, is measured in terms of transfer and time costs. "If the distance between market and supply is too great and too costly to overcome, interaction will not take place in spite of perfect complementarity and lack of intervening opportunity" (Ullman, 1966, p. 868). Ullman concluded that the real world movement of people and commodities between points or areas can be explained by the interplay between complementarity, intervening opportunity, and transferability. Ullman would have us believe that movement can be expected to be to the nearest market (this follows from the intervening opportunity concept) and that opportunities occurring outside of a circle whose diameter stretches from A to B would have absolutely no 
effect on spatial interaction between those two points or areas.

Transportation is the key to differentiation and interaction. "Organized transportation is a geographical factor -- an influence on the location of other economic activities; for without means of transport there would be no commercial coal mining, no production of surplus wheat, no commercial lumbering" (Alexander, p. 465). In fact, without a commercial transportation system the world's economy would become no more than subsistence economy, and regional specialization, which yields exchangeable surpluses, would be impossible. Transportation networks are made up of three fundamental elements: (1) origins, (2) routes, and (3) destinations. These man-made features are essential elements in geographic location and spatial interaction. However, the cost of using a transportation network is often as great an element in its importance as its actual presence. The variation in transportation cost is a geographical factor which influences the circulation of people and goods in a region. Also, this variation is a geographic element which can express the very characteristics of a region. The realization of this fact has led some port authorities to use freight rate schedules to delineate their general hinterlands. While these methods only superficially define the areal extent of the port's hinterland, they are valuable to the port authorities 
because the spatial delineation of a rate advantage hinterland provides a boundary for an area which a port can seek to develop.

Geographers seldom consider the effects of freight rate schedules. "... the very absence of recognition of freight rate analysis in geographic studies supports the conclusion that geographers are rather uniformed on spatial variations in such costs" (Alexander, Brown and Dahlberg, p. 553). Studies that considered the role of transport costs generally assume, due to a lack of evidence otherwise, that freight rate structures form concentric circles about transportation nodes. The lack of freight rate research has fostered two major misconceptions concerning freight rates: (1) freight rates assessed by the same form of transport increase, from any given point, equally in all directions, (2) freight rates always increase with distance (Alexander, Brown and Dahlberg, 1967). Freight rates are like tariffs; they are to regions and to urban centers what tariffs are to nations. Freight rates may be manipulated, as with tariffs, to the advantage or disadvantage of any given urban center or region.

\section{FLOW ANALYSIS}

Another method used for analyzing spatial interaction is flow analysis. "Flow" is the volume and direction of all movement of goods, people, and/or information. Thus, 
flows, and the interaction involved, are prime targets for geographical investigations from the diffusion of innovations to the movement of consumers and goods. Flow and movement are continuous phenomena, but in investigations are almost always considered to be static and discrete. Thus, "taking the existence of routes and stocks as given, we are now concerned with accounting for the volume of traffic that flows over different routes or through different nodes" (Smith, p. 130).

Many factors influence flows in general. In the case of foreign trade cargoes through ports there are two major classes of factors which influence the flow; exogenous, the most important, and endogenous (Sun, p. 156). The exogenous factors are regional, national and international in character and, therefore, mostly beyond an individual port's influence. These factors determine the magnitude of foreign trade cargoes. Endogenous factors are related to the ability of a port to perform its function of managing the transfer of goods. It is the endogenous factors that this thesis is going to analyze.

Most flow analyses involve considerations of demand (complementarity) and distance (friction) in an attempt to establish "yardstick flows." Yardstick flows are established when "the observed flows are arrayed against 'predicted' flows over the relative magnitude of the actual flows" (Smith, p. 133). The use of the distance variable as a 
predictor of commodity flow has been shown to provide reliable results. Using data on a total tonnage of commodities moving over various distances, by $25-\mathrm{mile}$ and 100 mile zones, Isard found that the impact of the distance variable, whether measured as miles or "economic" distance, is always present (Isard, 1956). It can be expected, however, that the significance of distance differs for various commodities. Certain flows, such as those of cement, are extremely sensitive to the distance variable while others, such as those of transistor radios and television sets are insensitive.

There have been many different methods used in commodity flow analysis. Inter-regional flow studies generalIy examine the precise distance and route characteristics of flows. In this type of analysis the terminals are central points within each producing and consuming area, and the volume of movement between origins and destinations are known. A variation involves studying inter-nodal flow. In this situation the terminals are specific urban centers or other transport terminals, and the routes and distances between nodes are known.

At the simplest level a variety of ratios and indices have been employed in the study of the volume of flows. An examination of the ratio of actual traffic at a center or along a route to the total available traffic in the 
hinterland results in the "traffic-capture" ratio. Other methods looks at the ratio of weight from a given origin to weight from all origins. Various ratios between terminating, originating, and highway bridge traffic over certain segments of a transportation network have also been used. All of these techniques are essentially descriptive, but they can be used as points of departure for further study.

Another investigative method involves the structure of flows rather than the flows themselves. Flow structure analysis considers the identification of generic locational characteristics of groups of origins, or of groups of destinations, or of groups of origins and destinations. "This type of analysis rests on the proposition that these clusters are not readily apparent from inspection of a pattern of commodity flow such as the flow matrix" (Smith, p. 139).

A few methods predict total flow on the basis of a hypothetical even share of that flow at all destinations, on national compared with regional shares (location quotients), on the traffic volumes at earlier times (shift techniques), or finally on the total amount received by each destination (transportation flows) (Smith, p. 137). Commodity flows through ports have been investigated using the relative shift technique where traffic volumes at time $t+1$ are projected on the basis of the time $t$ share. The 
problems involved with this technique are that it does not account for changes in shares and absolute gains may still constitute a relative loss. Location quotients, while not predictors themselves, are of considerable use as starting points in the prediction of flows (Isard, 1960, p. 123). Symbolically, transaction flow analysis states:

$$
R A_{i j}=\frac{A_{i j}-E_{i j}}{E_{i j}}
$$

Where $R A_{i j}=$ relative acceptance from origin $i$ to $A_{i j}=\begin{aligned} & \text { actual transaction (flow) from origin } i \text { to } \\ & \text { destination } j\end{aligned}$ $E_{i j}=$ expected transaction (flow) from $i$ to $j$

The calculation of expected flows is based on the assumptions of origin/destination independence and that flow from $i$ to $j$ reflects to total flow to $j$. Thus, in a data matrix with 1 to $\mathrm{n}$ columns (destinations) and 1 to $\mathrm{m}$ rows (origins), if the sum of column 3 was 10 percent of the sum of all column totals, this model would argue that origins $1,2,3, \ldots, \mathrm{m}$ should ship 10 percent of their respective row totals to destination 3. Whether or not this method is valid depends on the fit with reality. Another "... issue concerns the interpretation of the size of the relative acceptance measures, and their departure ( + or - ) from zero: how large must an index be to indicate salience?" (Smith, p. 134).

Simple linear correlation and regression analysis has 
been used frequently in the analysis of commodity flows, especially in situation involving one origin and many destinations, or vice versa. A form of gravity model has also been used in commodity flow analysis. In his study of Durban's hinterland, Shaffer (1965) did not explicitly draw on the gravity model, but his model for predicting traffic from (or to) a port to (or from) hinterland points resembles a multiple regression form of a gravity model (Shaffer, 1965). "In correlation-regression and gravitypotential methods of predicting volume flows, the level of explanation from distance (friction) and population (attractive mass) is high" (Smith, p. 137).

Investigation into the efficiency of flows is concerned with descriptive and normative characteristics of the routing of commodity flow patterns. Efficiency usually implies the minimizing of distance, or transportation costs. The efficiency criterion can involve the maximization of some quantity such as the flow over a given route or through a specified terminal. Smith argues that: "The formal technique most useful in the study of the efficiency of a commodity flow pattern is the linear programming transportation model" (Smith, p. 137).

In spite of the extensive work completed in the field of spatial interaction, no "best" theory has been forthcoming. Due to the complex nature of flow phenomena, it is not surprising "... that no single theory or concept has 
emerged which satisfactorily covers the real-world aspects of all spatial interaction" (Pred, 1967, p. 111). The reasons for this may lie in the common base found in most location and spatial interaction theories.

"In common with the economic man of other forms of economic theory, the locational decision-maker of traditional location theory inferentially has a single profit or cost or space utility goal, omniscient powers of preception, reasoning and computation, and is blessed with perfect predictive abilities" (Pred, 1967, p. 6). The criticisms of this "economic man" theory fall into three main groups. First, some dispute the logical consistency of the assumptions in this theory. The theory demands that action optimal for one economic unit depends on the actions of other units, and, it requires every unit to outguess all other units without being outguessed by them. Also, the theory implies a static market and population situation which is in fact dynamic over geographic space. Second, there are those who question the motives ascribed to economic man. An entrepreneur may only want a return that he considers satisfactory on his investment, or he may seek to optimize market share rather than profits. Third, some authors reject the knowledge level and mental acumen attributed to economic man. These three points are dismissed in general for their unwarranted departure from reality, and in particular because information is something that must be 
obtained rather than something that is given.

While these criticisms are powerful enough to quell universal acceptance of any one location and spatial interaction theory, they have not stopped the ongoing investigation and research in this field. Each new theory delving into the dynamic nature of applicable variables adds new knowledge in the quest for a "handle" on reality. It is probable that no "absolute" answer is attainable given the dynamic nature of the applicable variables over time and geographic space. However, continual development of theoretical approaches without consideration of pertinent practical data, as these data become available, is a problem. This can lead to building theory upon theory without injecting new data concerning reality into the "theory building system". 
CHAPTER III

\section{THE PORT OF PORTLAND'S CARGO MOVEMENT CLASSIFIED INTO FACILITY GROUPS}

The present task is to delineate the spatial extent of the major import and export facility hinterlands of the Port of Portland. The data utilized was for the calendar year 1973. The use of a full year smooths seasonal variation. Commodity volumes, origins and destinations vary over time and space. Using the latest full year established the contemporary facility hinterlands which may vary somewhat from year to year but should nevertheless provide a useful depiction.

The commodities that make up the total cargo of the Port of Portland are classified as bulk or general cargo. Bulk cargo moves unpacked in large quantities and, given the proper machinery, can be rapidly transfered from one carrier to another. Bulk cargo at the Port of Portland is further classified into liquid bulk, e.g., molasses, and dry bulk, e.g., flour, with special facilities to handle each type of movement. General cargo is everything, packed or unpacked, that is not carried in bulk. A further classification of general cargo is breakbulk and containerized cargo. Containerized cargo is general cargo moved in containers from origin to destination or, loaded in 
containers at dock side for shipment. Breakbulk cargo is the remainder of the general cargo. Special terminal facilities are provided at the Port of Portland for handing containerized and breakbulk cargo. The four main groups of facilities, dry bulk, breakbulk, container and liquid bulk, are designed to handle both imports and exports. In addition, the Port of Portland has special import facilities for steel and automobiles, and special export facilities for grain and logs. All of the Port of Portland facilities are assembled at four operating terminals (see Figure 2); Terminal 1, Terminal 2, Terminal 4, and Terminal 6. Terminal 6 does not pertain to this study because it was not operating in 1973.

A complete list of the import and export commodities handled at the Port of Portland in 1973 is provided in Appendix A. These commodities were grouped into the following facility classifications for the present task: EXPORT

Facility

Classification

Commodity

Grain

Liquid Bulk

Dry Bulk

Containerized

Logs

Breakbulk*
Wheat and Barley

Tallow, Tall Oil and Molasses

All other commodities exported in bulk All commodities exported in containers Logs

All commodities exported in breakbulk, except logs

* Excluding the noted exceptions above, breakbulk cargo includes everything not shipped in bulk or containers. 


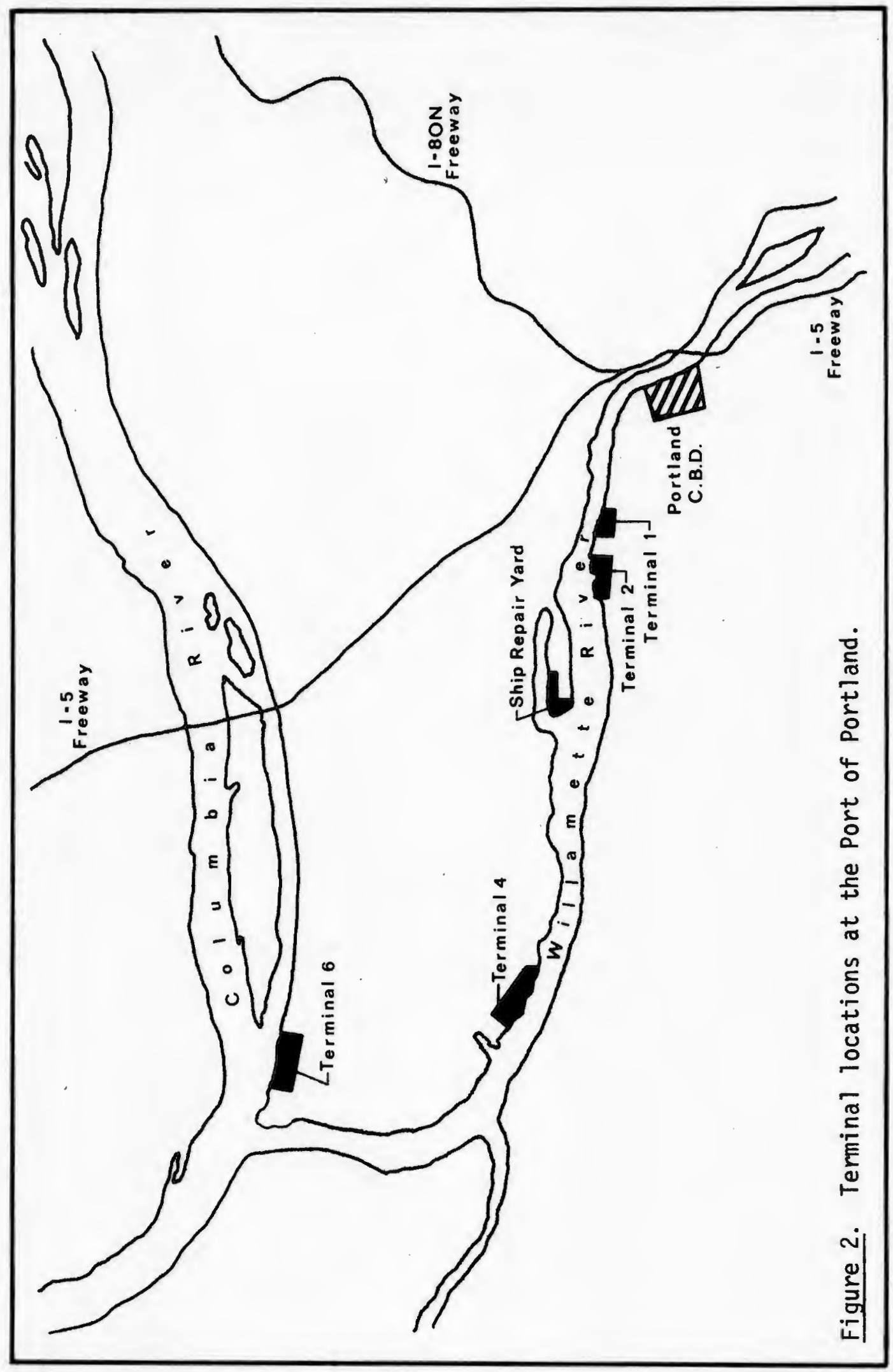




\section{IMPORT}

Facility Classification

Bulk

Containerized Automobiles Steel

Breakbulk*

\section{Commodity}

All commodities imported in bulk

All commodities imported in containers New and used automobiles Iron bars, iron sheets; steel flats and bars, steel beams, anglers and channels, steel coils, steel pipe and tubing, steel sheet and plate, and steel not elsewhere classified

All commodities imported in breakbulk except steel and automobiles as listed above

The classification above has two basic criteria. First, as mentioned before, the Port of Portland has special handling facilities for these particular categories. Second, the handling facilities and the above groups coincide with actual cargo movement, i.e., steel and automobiles are not exported, and logs and grain are not imported. Liquid bulk was deleted from the import facility group because no commodity was imported in liquid form through Port of Portland facilities.

The major data source used was the Port of Portland's 1973 Export and Import Domestic City Origin and Destination Report Quarterly Reports. These data are compiled from individual dock receipts and bills of lading. While this source has the most complete data available, it does have certain shortcomings. Despite continual double checking, human error persists in most massive data collections.

* Excluding the noted exceptions above, breakbulk cargo includes everything not shipped in bulk or containers. 
Inaccuracies can enter this report through mis-coded commodities, inaccurate weight statements, inability to read handwriting, and the placing of commodities into the wrong classification. Sharon Froberg, Port of Portland Research Technician, was responsible for the collection of the base data for the last three quarters of 1973. Ms. Froberg, in an interview, indicated that the data had an accuracy level of 80 to 90 percent. In large part, the possible errors involving individual commodities were minimized through the grouping of the data into facility groups.

An additional problem in the data source concerns identification of the actual origins and destinations of export and import cargo from the data. The origins and destinations as identified by the dock receipts and bills of lading are, in most cases, warehousing and distribution points. A port city is a focal point, a gateway, for inbound and outbound cargo. It is to be expected that Portland should have a larger than usual warehousing sector in its economy which handles a great deal of cargo that does not originate in, nor is destined for Portland. The data source, then, will over emphasize Portland as an origin and destination point for Port of Portland cargo. In order to delineate the facility hinterlands of the Port of Portland, the tonnage of cargo that is actually destined for or originates in Portland must be separated from the cargo which is just warehoused in Portland in transit. 
The analysis that follows breaks down the origins and destinations of the Port of Portland cargo as identified in the base data source. The tonnage indicated as originating in or destined for Portland will be extracted in Chapter IV. A sample will be taken from this tonnage in order to identify where it actually originated at or was destined for. The sample results will then be combined with the remaining origin and destination data in the current analysis to identify the Port of Portland facility hinterlands in Chapter V.

EXPORTS

The facility group breakdown of 1973 exports from Port of Portland facilities is shown in Table I. As indicated by Table I, 59.568 of exports consisted of grain.

TABLE I

1973 EXPORTS FROM

PORT OF PORTLAND FACILITIES

Facility Group

Liquid Bulk

Grain (wheat and barley)

Dry Bulk

Containerized

Logs

Breakbulk

Total
Short Tons Percent

$23,262.85$

$1,666,630.46$

$176,860.40$

$288,171.94$

$264,525.96$

$378,935.00$

$2,798,386.61$
0.83

59.56

6.32

10.30

9.45

13.54

100.00

The other bulks, liquid bulk and dry bulk, were 0.838 and 6.328 , respectively. The total bulk export movement 
amounted to 66.718 of all exports. Grain accounted for 89.288 of the bulk export moyement tonnage making it the predominant bulk facility group. Containerized, logs and breakbulk movement were $10.308,9.458$ and 13.548 respectively, of total export movement. The later three facility groups make up the general cargo exports. General cargo export movement was 33.298 of total exports. Containerized cargo, logs and breakbulk cargo represent $30.948,28.398$ and 40.678 respectively, of general cargo. Because containerized and breakbulk movement consists of various commodities, logs are the dominant single general cargo export. The origin of the predominant (grain and logs) as well as the lesser commodities that move through Port of Portland facilities, is of prime importance to marketing efforts for two major reasons: first, so that current widely dispersed areas can be identified, and second, so that widely dispersed areas that are weak can be strengthened through increased marketing efforts.

The city of origin breakdown for exports, by facilities, is shown in Appendix B.

\section{Liquid Bulk}

The origin of liquid bulk cargo by state, is shown in Table II. Portland dominated as origin for 85.718 of total exported liquid bulk and 98.168 of Oregon's tonnage, which was the major state of origin. Eastern Washington provided 7.078 of the liquid bulk exports, with Pasco as the origin 
of $92.86 \%$ of the Washington tonnage.

TABLE II

THE STATE ORIGINS OF 1973

LIQUID BULK EXPORTS FROM

PORT OF PORTLAND FACILITIES

\begin{tabular}{lrr} 
State & Short Tons & Percent \\
\cline { 2 - 3 } Montana & 174.39 & 0.75 \\
Oregon & $20,313.88$ & 87.32 \\
Washington & $1,643.50$ & 7.07 \\
Unknown & $1,131.08$ & 4.86 \\
Total & $23,262.85$ & 100.00
\end{tabular}

Oregon and Washington together provided 94.388 of the liquid bulk exports from the Port of Portland. Liquid bulk provides an example of a primary hinterland. Eastern Washington and oregon are geographically close to Port of Portland facilities and have good transportation linkage via highway, rail and water.

Grain

There were only two states of origin for grain. They were oregon and washington as shown in Table III.

TABLE III

THE STATE ORIGINS OF 1973

GRAIN EXPORTS FROM PORT OF PORTLAND FACILITIES

$\begin{array}{lrr}\text { State } & \text { Short Tons } & \text { Percent } \\ \text { Oregon } & 1,644,967.07 & 98.70 \\ \text { Washington } & 11.55 & 0.00 \\ \text { Unknown } & 21,651.84 & 1.30 \\ \text { Total } & 1,666,630.46 & 100.00\end{array}$


Portland was the only city of origin in Oregon. It therefore represented $98.70 \%$ of the grain exported from the Port of Portland in 1973. While Kalama was the only Washington city, it provided no representative percentages. Since grain is not grown in these cities, this is an example of the direct origin of commodities shipped being transshipment points rather than production origins.

\section{Dry Bulk}

The state origins for dry bulk are shown in Table IV. Like the previous export groups, Portland was the dominant city of origin with 39.118 of total dry bulk exports. Unlike the previous export groups, however, dry bulk had a second major city of origin in 1973, Lovell, Wyoming, with $23.30 \%$ of total dry bulk exports.

Alder, Montana, and Pocatello, Idaho, with $8.39 \%$ and 9.52\%, respectively, of total dry bulk exports, represented $100.00 \%$ of their state totals.

\section{TABLE IV}

THE STATE ORIGINS OF 1973

DRY BULK EXPORTS FROM

PORT OF PORTLAND FACILITIES

\begin{tabular}{|c|c|c|}
\hline State & Short Tons & Percent \\
\hline Idaho & $16,844.26$ & 9.52 \\
\hline $\begin{array}{l}\text { Montana } \\
\text { Oregon } \\
\text { Washington } \\
\text { Wyoming }\end{array}$ & $\begin{array}{r}14,838.05 \\
89,884.60 \\
5,013.16 \\
50,280.33\end{array}$ & $\begin{array}{r}8.39 \\
50.82 \\
2.84 \\
28.43\end{array}$ \\
\hline Total & $176,860.40$ & 100.00 \\
\hline
\end{tabular}


Portland origins represented 76.958 of all oregon origins. Oregon was the primary state of origin with Wyoming in second place. Idaho, lying between these two leading states, was less significant. This can be viewed as a spatially discontinuous hinterland (Wyoming) combined with a primary hinterland (Oregon).

Containerized

Table V indicates the state origins for 1973 containerized exports. In order of magnitude, the three highest states of origin were Oregon, Washington and Idaho with 69.688, 18.098 and $3.11 \%$, respectively. The remaining twenty-three origin states represented less than 18 each of containerized exports from the Port of Portland. Portland was the dominant city of origin with 37.058 of total containerized exports, and 53.168 of Oregon's total. Vancouver, Washington accounted for 12.448 of total containerized exports, and 68.748 of the Washington total.

TABLE V

THE STATE ORIGINS OF 1973 CONTAINERIZED EXPORTS FROM PORT OF PORTLAND FACILITIES

State

Alabama

Arizona

Arkansas

California

Canada

Idaho
Short Tons

2.45

447.49

487.74

112.45

80.27

$8,965.27$
Percent

0.00

0.16

0.17

0.04

0.03

3.11 


$\begin{array}{lrr}\text { Illinois } & 25.99 & 0.01 \\ \text { Indiana } & 5.50 & 0.00 \\ \text { Iowa } & 40.03 & 0.01 \\ \text { Michigan } & 3.77 & 0.00 \\ \text { Minnesota } & 24.25 & 0.01 \\ \text { Montana } & 567.50 & 0.20 \\ \text { Nebraska } & 116.64 & 0.04 \\ \text { New Hampshire } & 507.50 & 0.18 \\ \text { New Jersey } & 20.86 & 0.01 \\ \text { Nevada } & 68.81 & 0.02 \\ \text { Oregon } & 200818.06 & 69.68 \\ \text { Pennsylvania } & 33.12 & 0.01 \\ \text { Tennessee } & 159.89 & 0.06 \\ \text { Texas } & 175.47 & 0.06 \\ \text { Utah } & 137.54 & 0.05 \\ \text { Virginia } & 124.92 & 0.04 \\ \text { Washington } & 52,132.94 & 18.09 \\ \text { Washington, D.C. } & 15.50 & 0.01 \\ \text { Wisconsin } & 38.18 & 0.01 \\ \text { Wyoming } & 1,201.67 & 0.42 \\ \text { Unknown } & 21,858.13 & 7.58 \\ \text { Total } & & \\ \text { Total } & 288,171.94 & 100.00\end{array}$

The major Idaho city of origin was Twin Falls with $21.55 \%$ of the state total. However, Twin Falls accounted for only $0.67 \%$ of the total containerized exports. The spatial distribution, by magnitude, of origins indicates two hinterlands; primary and secondary. The primary hinterland is centered around Portland, and diminishes with distance eastward to Idaho. The remaining origins indicate that, while the Port of Portland gets some containerized exports from these areas, it is in competition with other ports for containerized cargo exported from these other ports.

Logs

There were only two states of origin for logs. This 
is indicated in Table VI.

TABLE VI

THE STATE ORIGINS OF 1973

LOG EXPORTS FROM PORT OF PORTLAND FACILITIES

$\begin{array}{lrr}\text { State } & \text { Short Tons } & \text { Percent } \\ \text { Oregon } & 230,409.45 & 87.10 \\ \text { Washington } & 5,493.49 & 2.08 \\ \text { Unknown } & 28,623.02 & 10.82 \\ \text { Total } & 264,525.96 & 100.00\end{array}$

Vancouver, Washington accounted for $93.86 \%$ of its state's total and 1.958 of total log exports. Portland dominated all oregon origins with $76.74 \%$ of the state, and 66.848 of total $\log$ exports. The log hinterland appears to be a very compact primary hinterland.

Breakbulk

The distribution of state origins for breakbulk is shown in Table VII. Breakbulk displayed the most extensive spatial distribution among the exports.

However, the hinterland appears to be of a primary nature, decreasing in magnitude with distance. Oregon provided 77.418 of the breakbulk exports, and Portland dominated oregon city origins with 17.35\%. Portland also was the major city for total breakbulk exports with 13.438 . Washington was the second highest breakbulk originating state with 15.20\%. Vancouver was the largest origin city in Washington with 13.818. As distance increases and ease 
of accessability decreases from Port of Portland facilities, the percentage of breakbulk provided decreased. After Oregon and Washington follow, Idaho, Wyoming, Utah, Montana, and California with $2.20 \%, 1.71 \%, 0.77 \%, 0.458$, and $0.23 \%$, respectively. Wyoming's major city of origin was Cody with 92.188 of the state's total. Montana, Utah and California indicated a lesser degree of centralization. Their major cities were Three Forks, Montana, with 59.35\%, Ironton, Utah, with 52.75\%, and Weed, California, with 49.428. Idaho displayed the least centralization with only 15.638 of its breakbulk exports originating in one city, Troy. All of the remaining states provided the origin for less than 225 short tons each, or $0.06 \%$ of total breakbulk exports.

\section{TABLE VII}

THE STATE ORIGINS OF 1973

BREAKBULK EXPORI'S FROM

PORT OF PORTIAND FACILITIES

\begin{tabular}{lrr} 
State & Short Tons & Percent \\
\cline { 2 - 2 } Arizona & 3.93 & 0.00 \\
Arkansas & 46.21 & 0.01 \\
California & 868.26 & 0.23 \\
Canada & 133.99 & 0.04 \\
Connecticut & 1.32 & 0.00 \\
Idaho & 834.45 & 2.20 \\
Illinois & 140.48 & 0.04 \\
Iowa & 20.98 & 0.01 \\
Louisiana & 1.50 & 0.00 \\
Maine & 0.02 & 0.00 \\
Michigan & 29.77 & 0.01 \\
Minnesota & 11.27 & 0.00 \\
Mississippi & 46.21 & 0.01 \\
Montana & $1,705.81$ & 0.45 \\
Missouri & 0.26 & 0.00
\end{tabular}




$\begin{array}{lrr}\text { New Hampshire } & 161.98 & 0.04 \\ \text { New Jersey } & 10.31 & 0.00 \\ \text { Nevada } & 221.62 & 0.06 \\ \text { Ohio } & 2.25 & 0.00 \\ \text { Oregon } & 293,328.25 & 77.41 \\ \text { Pennsylvania } & 198.93 & 0.05 \\ \text { South Dakota } & 185.50 & 0.05 \\ \text { Texas } & 128.65 & 0.03 \\ \text { Utah } & 2,930.69 & 0.77 \\ \text { Washington } & 57,609.77 & 15.20 \\ \text { Wisconsin } & 4.70 & 0.00 \\ \text { Wyoming } & 6,461.04 & 1.71 \\ \text { Unknown } & 6,331.85 & 1.67 \\ \text { Total } & 378,935.00 & 99.99 *\end{array}$

\section{IMPORTS}

The five facility group breakdown of 1973 imports from Port of Portland facilities is shown in Table VIII. Unlike exports, there is no markedly dominant facility group for imports. Steel, bulk and breakbulk are the top three with $42.328,29.248$ and 13.938 , respectively. Containerized cargo and automobiles are less important with 9.058 and $5.46 \%$, respectively.

With bulk as the exception, all the import facility groups combine to comprise general cargo. General cargo, therefore, represents 70.768 of the Port of Portland's imports. The predominant general cargo commodity is steel. However, this may be due to weight factors rather than volume factors.

The city of destination breakdown for import facilities is in Appendix $C$.

* Total does not add to 1008 due to rounding. 
TABLE VIII

1973 IMPORTS THROUGH

PORT OF PORTLAND FACILITIES

\begin{tabular}{lrr} 
Facility Group & Short Tons & Percent \\
\cline { 2 - 3 } Bulk & $195,853.51$ & 29.24 \\
Containerized & $60,648.67$ & 9.05 \\
Steel & $283,469.68$ & 42.32 \\
Automobiles & $36,586.18$ & 5.46 \\
Breakbulk & $93,270.60$ & 13.93 \\
Total & $669,828.69$ & 100.00
\end{tabular}

Bulk

The state of Oregon was the destination for 99.348 of bulk imports through Port of Portland facilities. This is shown in Table IX. The only other state that received imported bulk was Washington.

TABLE IX

THE STATE OF DESTINATION OF 1973

BULK IMPORTS THROUGH

PORT OF PORTLAND FACILITIES

\begin{tabular}{lrr} 
State & Short Tons & Percent \\
\cline { 2 - 2 } Oregon & $194,560.20$ & 99.34 \\
Washington & 816.26 & 0.42 \\
Unknown & 477.05 & 0.24 \\
Total & $195,853.51$ & 100.00
\end{tabular}

Portland was the recipient of 100.008 of Oregon's total and Tacoma received 99.938 of Washington's. Due to the high percentage shown by Portland, one could generalize that the import bulk hinterland does not extend beyond the 
local area surrounding the Port of Portland facilities, Tacoma aside.

Containerized

The state destinations for containerized cargo are shown in Table $x$. Oregon, Washington and Illinois are the highest states with $74.278,16.458$ and 5.028 , respectively.

TABLE $\mathrm{X}$

THE STATE OF DESTINATION OF 1973 CONTAINERIZED IMPORTS THROUGH PORT OF PORTLAND FACILITIES

\begin{tabular}{|c|c|c|}
\hline State & Short Tons & Percent \\
\hline Alaska & 43.56 & 0.07 \\
\hline California & 124.27 & 0.21 \\
\hline Canada & 44.29 & 0.07 \\
\hline Idaho & 290.42 & 0.48 \\
\hline Illinois & $3,042.94$ & 5.02 \\
\hline Iowa & 3.56 & 0.01 \\
\hline Kansas & 13.69 & 0.02 \\
\hline Michigan & 222.32 & 0.37 \\
\hline Minnesota & 14.43 & 0.02 \\
\hline Montana & 79.80 & 0.13 \\
\hline Nevada & 2.21 & 0.00 \\
\hline New Jersey & 60.33 & 0.10 \\
\hline New York & 245.51 & 0.41 \\
\hline Ohio & 78.99 & 0.13 \\
\hline Oregon & $45,041.45$ & 74.27 \\
\hline Pennsylvania & 3.40 & 0.01 \\
\hline Tennessee & 9.11 & 0.02 \\
\hline Texas & 272.85 & 0.45 \\
\hline Utah & 50.93 & 0.08 \\
\hline Washington & $9,977.76$ & 16.45 \\
\hline Wisconsin & 63.86 & 0.11 \\
\hline Wyoming & 12.41 & 0.02 \\
\hline Unknown & 950.58 & 1.57 \\
\hline Total & $60,648,67$ & $100.02 *$ \\
\hline
\end{tabular}


Portland is the highest destination city with 58.308 of total containerized imports and 78.508 of Oregon's containerized imports.

The dominant Washington destination city was Longview with $56.35 \%$ of that state's total. Illinois was a unique case. The dominant destination city in Illinois is South Holland with $61.98 \%$ of the state total. The Port of Portland owns its own warehouse in South Holland, Illinois, and sends import cargo bound for the Midwest and East to that warehouse for transshipment. Allowing for this discrepancy, the containerized hinterland appears to be predominantly a primary one around Portland and Longview. The remaining destination points indicate varying degrees of competitiveness in a secondary hinterland.

Steel

The destination states for steel are fewer than those for containerized cargo. This is evident in Table XI. The dominant states are Oregon, Washington and Idaho with $89.898,4.638$ and $1.60 \%$, respectively. Portland is again the major destination city with 76.478 of the total import steel and 85.078 of Oregon's import steel. Washougal, Washington was the destination of 48.618 of Washington's steel imports.

However, Washougal represents only 2.258 of total steel imports. In this category, Eugene, Oregon, and Salem, Oregon, surpassed Washougal with 5.358 and 2.678 , respec- 
tively. The major steel importing cities in Idaho were

TABLE XI

THE STATE OF DESTINATION OF 1973

STEEL IMPORTS THROUGH

PORT OF PORTLAND FACILITIES

\begin{tabular}{lrrr} 
State & Short Tons & Percent \\
\cline { 2 - 2 } California & $1,290.84$ & 0.46 \\
Canada & 31.61 & 0.01 \\
Idaho & $4,521.86$ & 1.60 \\
Illinois & 8.58 & 0.00 \\
Montana & 623.51 & 0.22 \\
New York & 23.08 & 0.01 \\
Oregon & $254,805.41$ & 89.89 \\
Utah & 158.09 & 0.06 \\
Washington & $13,128.00$ & 4.63 \\
Wyoming & $8,878.67$ & 0.00 \\
Unknown & & 3.13 \\
Total & $283,469.68$ & $100.01 *$
\end{tabular}

Boise and Twin Falls, with 40.178 and 38.288 of the state total, respectively. The hinterland is primary for the steel imports passing through the Port of Portland. A secondary hinterland is evident, but to a much smaller degree than with imported containerized cargo.

Automobiles

The hinterland for imported automobiles coming through Port of Portland facilities is primary in nature. This can be seen in Table XII.

* Total does not add to 1008 due to rounding. 


\section{TABLE XII}

THE STATE OF DESTINATION OF 1973

AUTOMOBILE IMPORTS THROUGH

PORT OF PORTLAND FACILITIES

\begin{tabular}{lrrr} 
State & Short Tons & Percent \\
\cline { 2 - 3 } Oregon & $35,700.15$ & 97.58 \\
Washington & 830.91 & 2.27 \\
Unknown & 55.12 & 0.15 \\
Total & $36,586.18$ & 100.00
\end{tabular}

Oregon was the destination for 97.588 of the imported automobiles passing through Port of Portland facilities, 96.138 of this amount to the Portland area. Next to Portland, Tigard received 3.688 of the state total. Washington was the destination of only 2.278 of the imported automobiles, and 78.968 of this amount to seattle.

Breakbulk

Imported breakbulk cargo passing through Port of Portland facilities appears to have a primary hinterland. Oregon was the destination for 79.898 of this type of cargo, with washington and Idaho following with 13.028 and 2.028 , respectively. A secondary hinterland of lesser significance is apparent.

Portland was again the dominant destination city with $64.56 \%$ of the total imported breakbulk and 80.818 of the Oregon total. Vancouver, Washington, was the major destination city of that state with 59.218 , and Boise had 
TABLE XIII

THE STATE OF DESTINATION OF 1973

BREAKBULK IMPORTS THROUGH

PORT OF PORTLAND FACILITIES

State

Alaska

Arkansas

California

Canada

Colorado

Idaho

Illinois

Kansas

Louisiana

Maryland

Michigan

Minnesota

Montana

Nebraska

Nevada

New York

Ohio

Oregon

Rhode Island

South Dakota

Tennessee

Texas

Utah

Washington

Wisconsin

Unknown

Total

\begin{tabular}{rrr} 
Short Tons & & Percent \\
\cline { 1 - 1 } 14.00 & & 0.02 \\
1.99 & & 0.00 \\
432.74 & & 0.46 \\
30.95 & & 0.03 \\
4.59 & & 0.01 \\
$1,886.55$ & & 2.02 \\
101.18 & & 0.11 \\
1.65 & & 0.00 \\
38.77 & & 0.04 \\
112.41 & & 0.12 \\
1.77 & & 0.00 \\
37.62 & & 0.04 \\
275.80 & & 0.30 \\
243.11 & 0.26 \\
$1,386.91$ & 1.49 \\
0.43 & & 0.00 \\
132.09 & 0.14 \\
$74,513.02$ & & 79.89 \\
0.01 & 0.00 \\
2.92 & 0.00 \\
9.04 & 0.01 \\
70.91 & 0.08 \\
239.07 & 0.26 \\
$12,145.96$ & 13.02 \\
1.10 & 0.00 \\
$1,586.01$ & 1.70 \\
$93,270.60$ & 100.00
\end{tabular}

44.248 of Idaho's total. Vancouver represented the destination of 7.718 of total imported breakbulk, and Boise represented 0.898 .

CONCLUSIONS 
Portland facilities originate in a primary hinterland: Oregon. Table XIV indicates that more than 508 of exports from all facility groups originated in oregon.

\section{TABLE XIV}

\section{OREGON AND PORTLAND ORIGIN PERCENTAGES \\ OF 1973 EXPORTS FROM \\ PORT OF PORTLAND FACILITIES}

\section{Facility \\ Group}

Liquid Bulk

Grain (wheat and barley)

Dry Bulk Containerized Logs

Breakbulk
\% Originating in Oregon

87.32

98.70

50.82

69.68

87.10

77.42
\% Originating in Portland

85.71

98.70

39.11

37.05

66.84

13.43
Portland Origins as a of of Oregon Origins

$$
92.86
$$

100.00

76.95

53.16

76.74

17.35

only dry bulk and containerized cargo indicate a significant secondary hinterland. All other facility groups have in excess of $75 \%$ of their origins in Oregon. Portland represents the degree of spatial compactness of the primary hinterland. Portland origins accounted for over $75 \%$ of four of the six facility group exports. Containerized and breakbulk cargo were the exceptions. However, the exceptions were still dominated by oregon indicating more diversified origins within the primary hinterland rather than a greater spatial extent of that hinterland.

\section{Imports}

The import data indicates an even more compact primary 
hinterland in Oregon, with Portland as an even stronger focus.

In all facility groups more than 748 of the destinations were in Oregon. Portland destinations accounted for more than 588 of tonnage through all facility groups. Portland represented over 788 of tonnage to Oregon destinations for all import facility groups. As with exports, a secondary hinterland is evident, but to a lesser extent.

TABLE XV

OREGON AND PORTLAND DESTINATION PERCENTAGES

OF 1973 IMPORTS THROUGH

PORT OF PORTLAND FACILITIES

\begin{tabular}{|c|c|c|c|}
\hline $\begin{array}{l}\text { Facility } \\
\text { Group }\end{array}$ & $\begin{array}{l}8 \text { with } \\
\text { Destinations } \\
\text { in Oregon }\end{array}$ & $\begin{array}{l}8 \text { with } \\
\text { Destinations } \\
\text { in Portland }\end{array}$ & $\begin{array}{c}\text { Portland } \\
\text { Destinations as } \\
\text { a of oregon } \\
\text { Destinations }\end{array}$ \\
\hline $\begin{array}{l}\text { Bulk } \\
\text { Containerized } \\
\text { Steel } \\
\text { Automobiles } \\
\text { Breakbulk }\end{array}$ & $\begin{array}{l}99.34 \\
74.27 \\
89.89 \\
97.58 \\
79.89\end{array}$ & $\begin{array}{l}99.34 \\
58.30 \\
76.47 \\
93.98 \\
64.56\end{array}$ & $\begin{array}{r}100.00 \\
78.50 \\
85.07 \\
96.31 \\
80.81\end{array}$ \\
\hline
\end{tabular}

The conclusions drawn from the above data must be seen in the proper perspective. The hinterlands, as identified, are not necessarily ultimate origin or destination hinterlands, but rather they are hinterlands of transshipment points. To obtain the ultimate origin for exports, i.e., a farmer's field, or ultimate destination for imports, i.e., a consumer's home, would require research far beyond the scope of the current effort. If one accepts that primary 
(ultimate) consumers and producers abide by the "transportation cost minimization" ideal, then it is reasonable to treat transshipment points as the ultimate origin and destination points for the purpose of delineating port facility hinterlands. The assumption is that if imports are shipped to a transshipment point, Boise, Idaho for instance, the ultimate destination is in Boise or in close proximity to Boise, and commodities produced for export are assumed to have originated in or near the place of transshipment. Portland must be an exception to this assumption due to its nature as a port city, and thus, a major transshipment point.

This accounts for Portland's dominance as an origin and destination point since the data represents the first transshipment point for imports and the last transshipment point for exports. The hinterland of Port of Portland facilities, then can not be completely ascertained until the origins and destinations of Portland cargo has been identified. The following chapter will attempt to identify those origins and destinations. Chapter $\mathrm{V}$ will combine the current data with that in Chapter IV and show the mapped results with concluding comments. 


\section{PORTLAND'S VOLUME AS AN ULTIMATE ORIGIN} AND DESTINATION POINT

As pointed out in the last chapter, Portland's predominance as an origin and destination point in the movement of goods through the Port of Portland is tempered by it's nature as a, port city. In order to delineate the Port of Portland's hinterland it is necessary to quantitatively identify the tonnage of goods that was actually destined for or originated in Portland, and the tonnage warehoused in Portland only for transshipment purposes.

In an attempt to ascertain the volume of cargo, by facility group, that actually originated in or was destined for Portland, a questionnaire was sent to the exporters and importers which, according to the 1973 Export and Import Domestic City Origin and Destination Report Quarterly Reports, handled cargo originating in or destined for Portland. The exporters and importers who received questionnaires included all those who shipped or received 100 tons or more of cargo in any given quarter of 1973. A list of the exporters and importers who were sent questionnaires is in Appendix D.

Due to the limited scope of this project, financial constraints, and the expected less than full involvement 
by the respondents, sending a questionnaire to the entire population was impossible. A random sample was considered inappropriate because the population data distribution is not normal but highly concentrated. Including all exporters and importers who handled 100 tons or more in any given quarter of 1973 provided the best coverage of tonnage moved. Questionnaires were sent to each firm selected asking for city and state origins and/or destinations, by percentage, of their total movement in 1973. A copy of the export and import questionnaire is in Appendix E. Percentages were sought because it was felt that a larger response would result than if tonnages were requested. Each firm's respective percentages were, however, applied to their 1973 tonnage by facility group, as shown in the 1973 Export and Import Domestic City Origin and Destination Report Quarterly Reports.

\section{EXPORTS}

A total of 78 export questionnaires were sent out. Table XVI indicates the total exporter returns by facility group. The number of returned export questionnaires, 41 , represents a 538 response. Table XVI also indicates tonnage and percentage of returned export questionnaires by facility group, and the percentage the response represents of the total tonnage which the 1973 Export and Import Domestic City Origin and Destination Report Ouarterly 


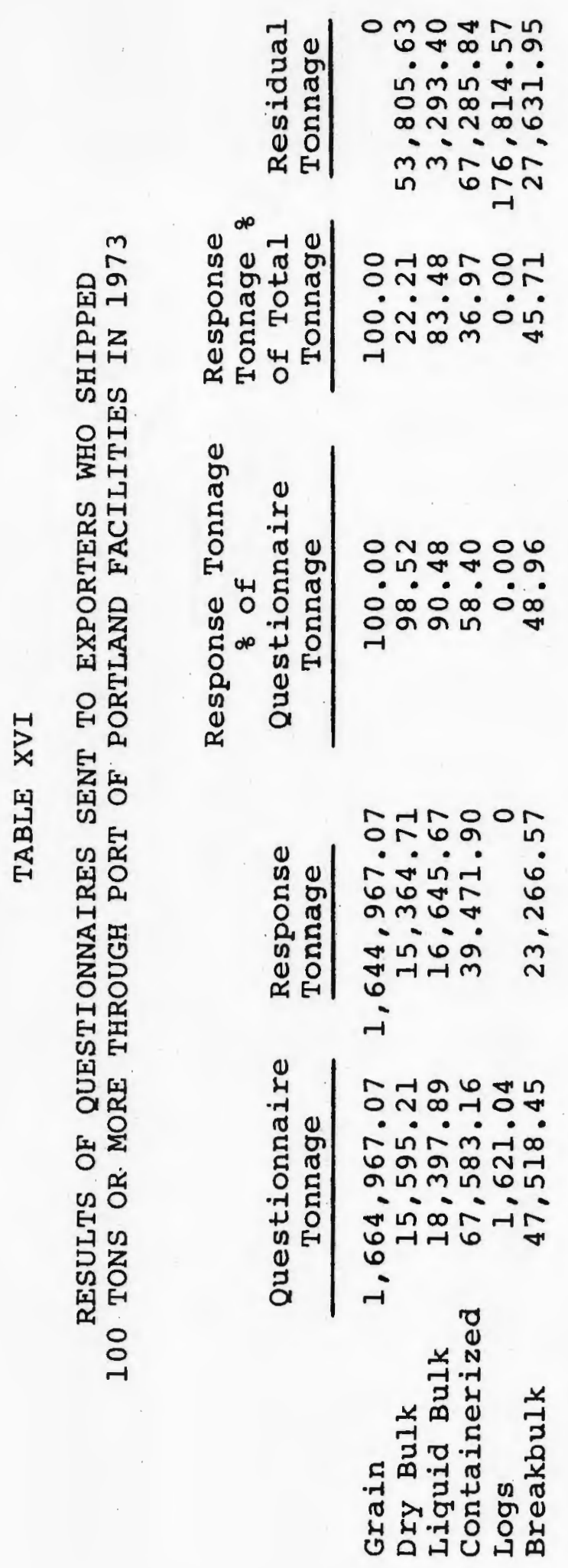


Reports indicated originated in Portland. The residual tonnage indicates the portion of Portland originating cargo, as shown by the above report, which is left unexplained by the responses.

While the questionnaires asked for city and state of origin, most returns listed state origins only. Therefore, the data were arranged into state origins.

Grain

The response for grain represented $100.00 \%$ of the total grain movement. Thus, the state origins can be shown without a residual factor. Table XVII indicates that the grain originally showing a Portland origin actually originated over a six state area with Montana, Washington and oregon dominating as state origins.

$\underline{\text { Dry Bulk }}$

The responses for dry bulk sample represented 22.218 of the total dry bulk movement. The residual, 53,805.63 tons, was allocated to the states according to the percentage each state represented of the responses. The results are shown in Table XVIII.

Again, the response indicates origins over a six state area with Oregon, Montana and Washington dominating.

Liguid Bulk

The liquid bulk response accounted for $16,645.67$ tons 


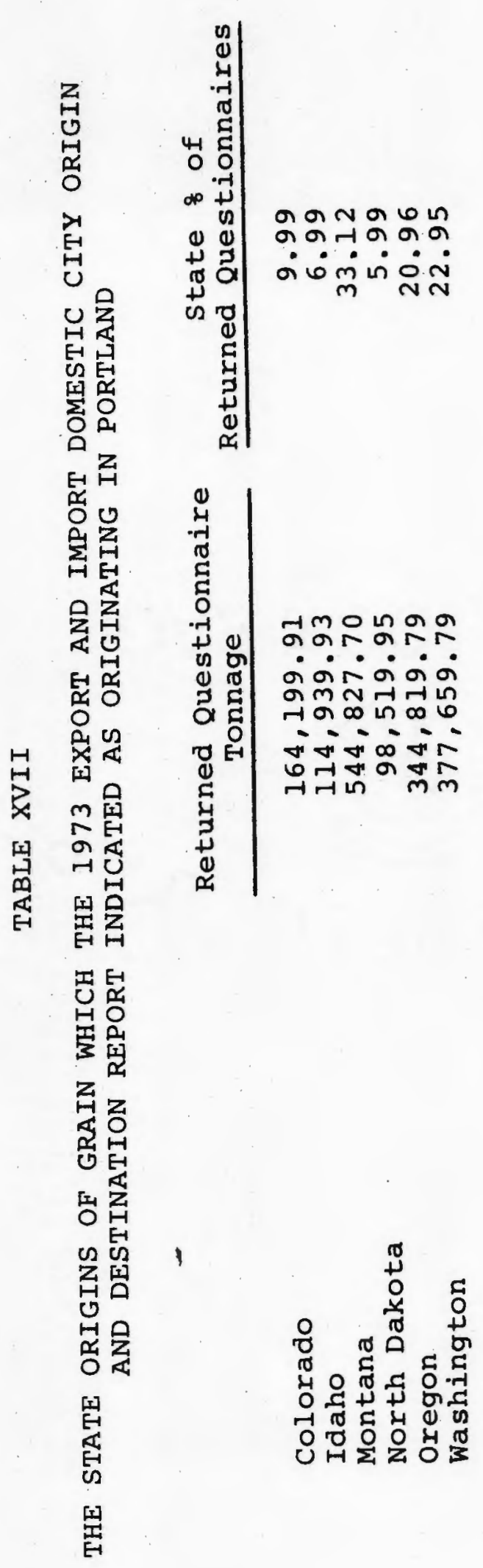




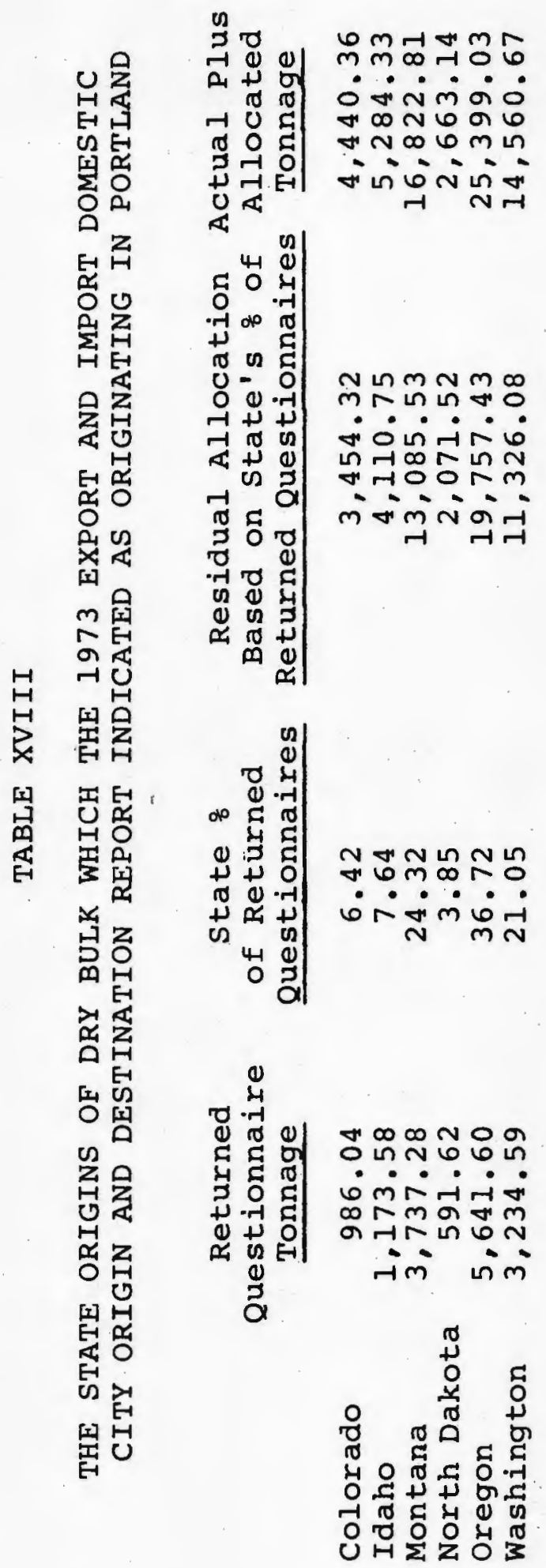


of the 19,939.07 total tons, or 83.488 . The residual of $3,293.40$ tons was allocated to the states represented in the liquid bulk response in the same manner as dry bulk. The results are indicated in Table XIX.

oregon is by far the largest of the four state origins, with 85.798 .

Containerized

The residual tonnage of the containerized response, $67,285.84$ tons, was applied to the 36.928 response, again, according to state percentages in the returned questionnaire. Table XX shows the results. Oregon, Washington, and Idaho were the only states higher than 18 of the responses with $89.9778,5.9798$, and 3.2778 , respectively.

Logs

There were no returns for logs. Those exporters sent questionnaires, however, represented only $0.92 \%$ of the tonnage originally indicated as originating in Portland. It would have been tenuous, at best, to work with that size response. This does not indicate that exporters of logs only handled less than 100 tons each. Most of the shippers of logs were listed as unknown and could, therefore, not be identified.

Breakbulk

Table XXI indicates the response for breakbulk. The $27,631.95$ ton residual was allocated by the individual 


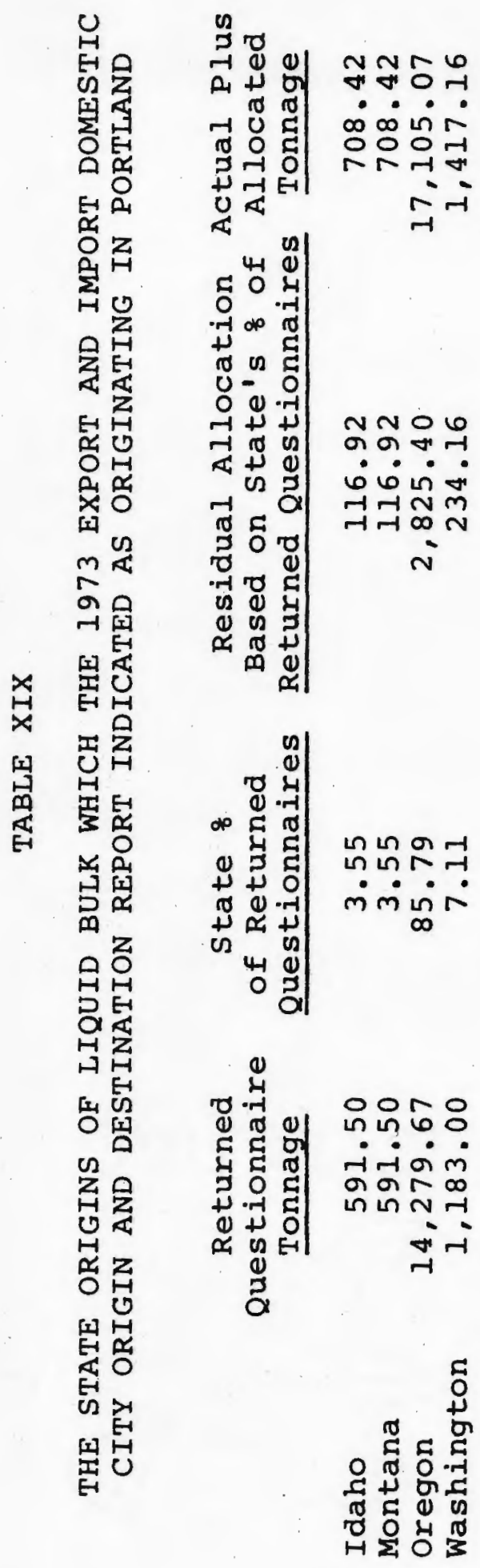




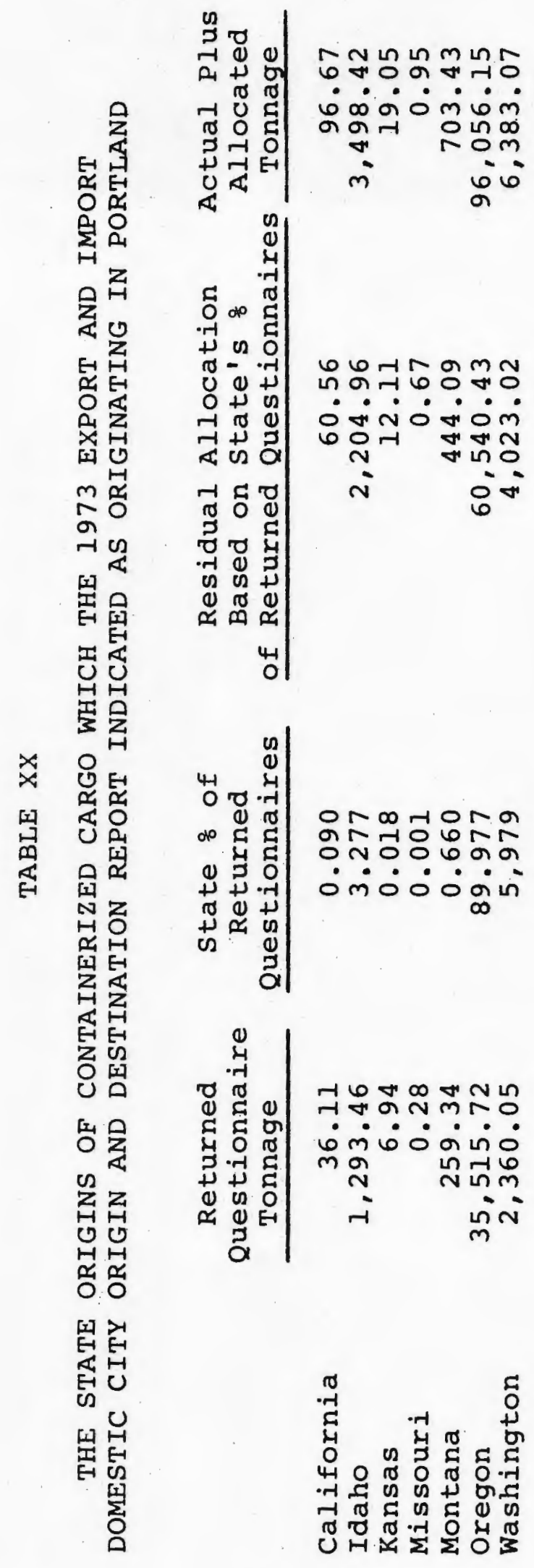




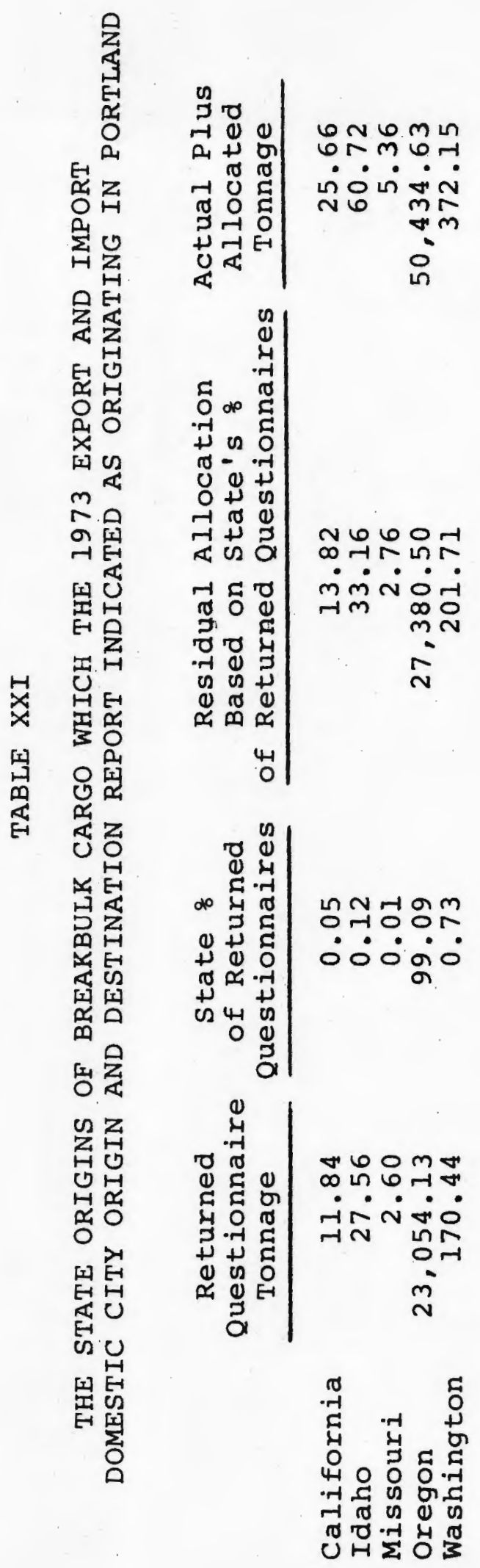


state percentage of the responses.

Oregon was by far the largest origin state with 99.098 .

\section{IMPORTS}

A total of 154 import questionnaires were sent out, of which 468 , or 71 questionnaires were returned. Table XXII indicates the total importer questionnaire size by facility group. Also indicated is the tonnage and percentage of returned import questionnaires by facility group, and the percentage the response represents of the total 1973 tonnage previously shown as having a Portland destination.

As with the export questionnaires, the import returns indicated predominately state rather than city of destination. Therefore, the import data were arranged into state destinations.

Bulk

The response for bulk accounted for $36.80 \%$ of the total bulk movement. Table XXIII includes the results of the bulk response. The residual, 122,956.04 tons, was allocated to Oregon and Washington based on their respective percentages of the responses.

Automobiles

Table XXIV includes the results of the automobile questionnaire. The responses accounted for 25.958 of the total 1973 automobile tonnage that originally indicated 


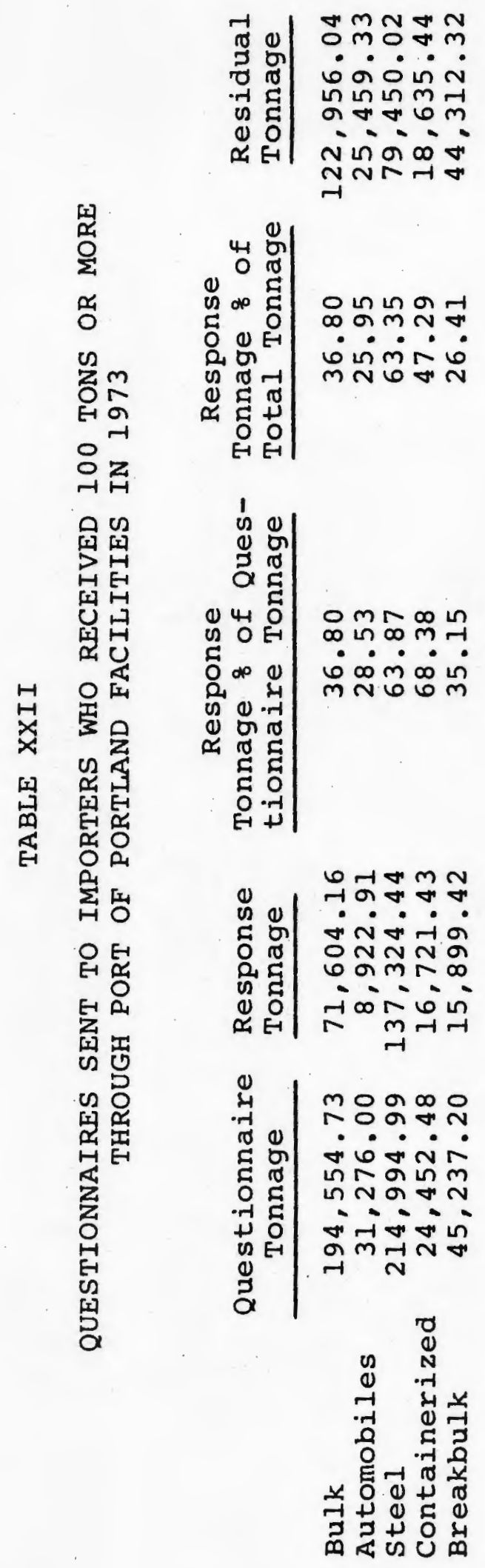




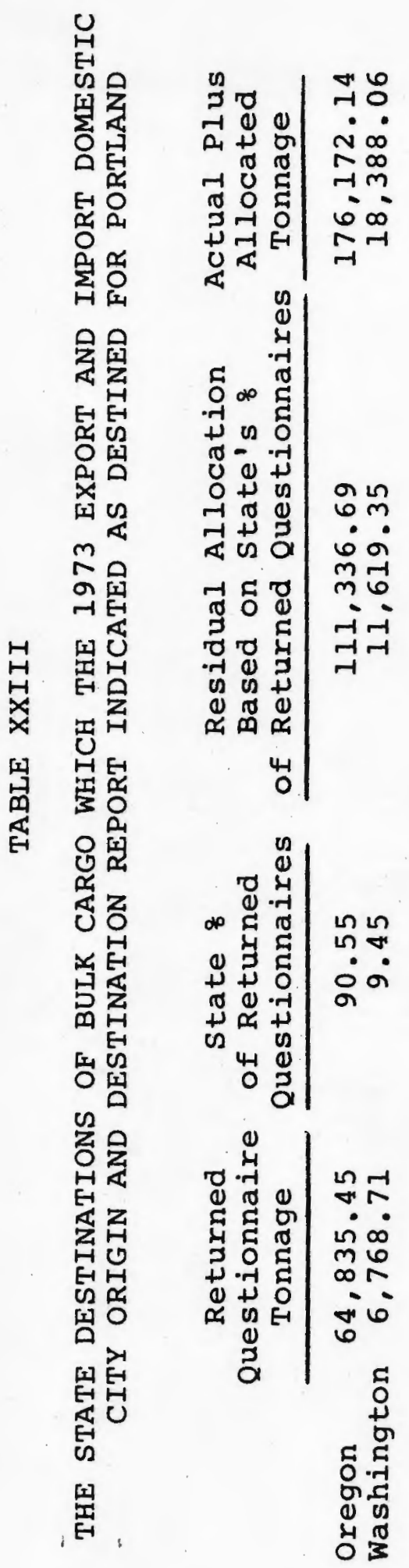




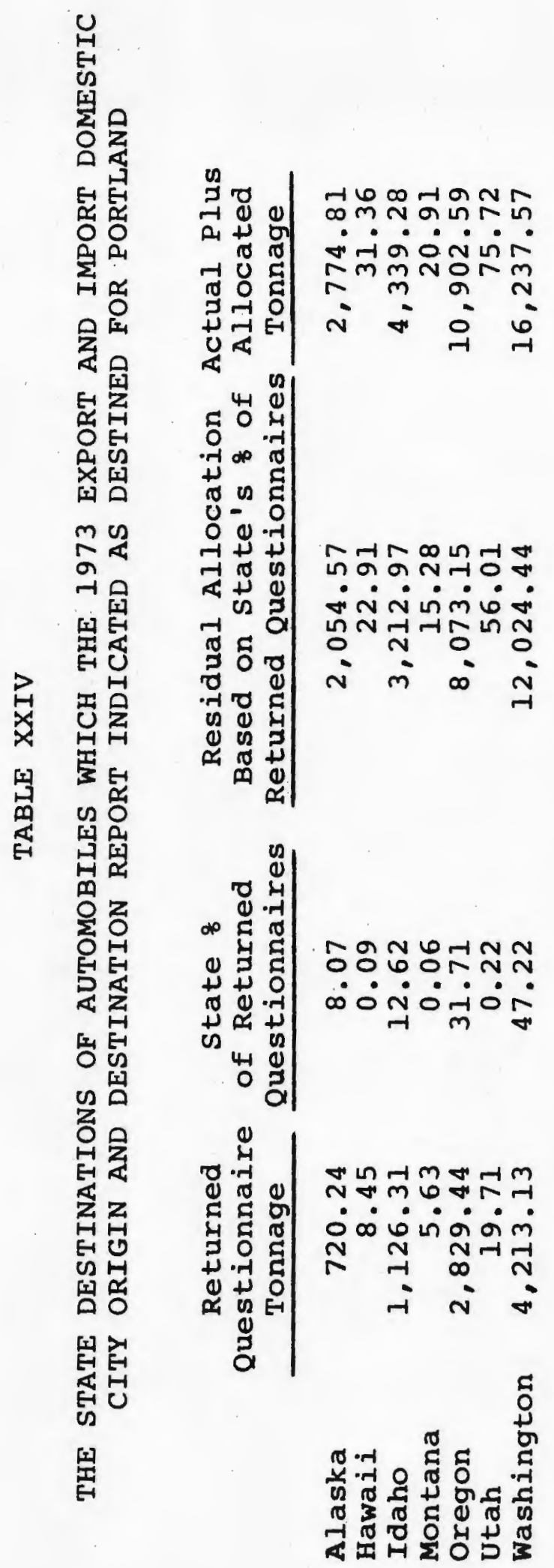


Portland as a destination. Seven states were represented in the responses. Washington and oregon were the largest destination states. The 25,459.33 ton residual was applied, as with all previous facility groups, according to each states' percentage of the responses.

Steel

The steel response represented $63.35 \%$ of the steel movement previously indicated as destined for Portland. Table XXV contains results from the steel questionnaire. The response accounted for destinations in six states and British columbia with a $79,450.02$ ton residual. The residual was again allocated to each destination based on that destinations percentage of the responses.

\section{Containerized}

Results of the containerized questionnaire are shown in Table XXVI. The residual, 18,635.44 tons, was allocated, in the same manner as above, among the ten states represented in the 47.298 response.

The containerized response contained a much broader geographical coverage than any of the facility group responses discussed above. However, Oregon was the largest destination state with 67.0248 .

\section{Breakbulk}

The breakbulk response represented as broad a state destination coverage as the import containerized response. 


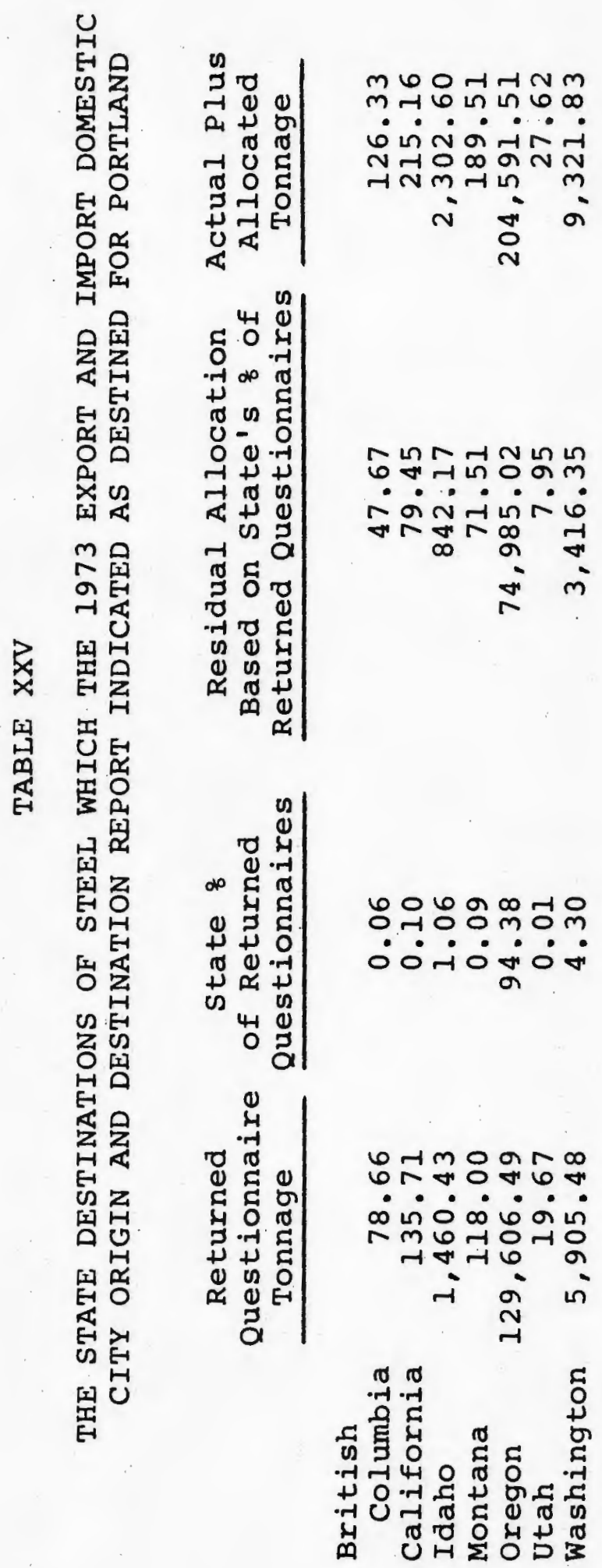


告

告

a

Ex 0

0

ค.

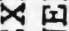

(a) z

$M+$

$M$ E

on al

म०

돈

E-

$\rightarrow \stackrel{8}{x}$

U

$\rightarrow 4$

$\mapsto \quad 3$

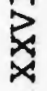

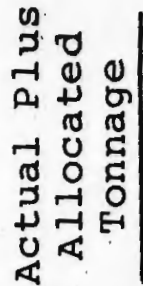

n) $m$ in $m \sim \infty m \sim 6$

o $6 N H N+6 \infty \mathrm{r}$ ?

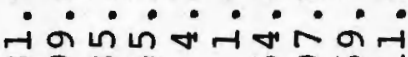

$\infty$ or $\infty$ in 0

$\rightarrow$ m $m \neq 0$

$\rightarrow$ minf

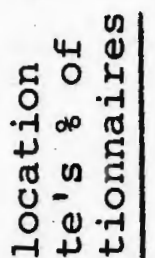

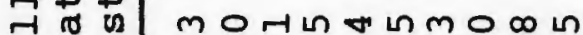
$4+40$

m

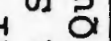

m. $\cdot \dot{0}: \dot{0} \cdot \dot{0}$ mNNNNONONM

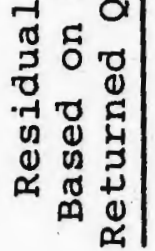

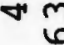
ngrm त $\mathrm{H}$

0

(I) E

$\rightarrow$ O

E1

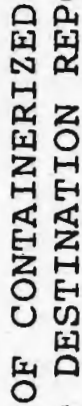

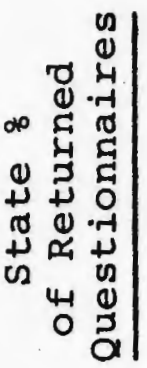

$N m+n \sim+\infty \sim r$

$m$ ब 4 HO 0 N

NmN

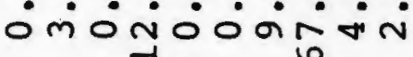

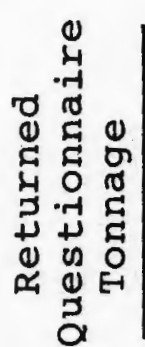

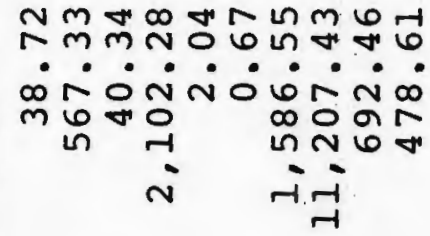

[द]

될

[a] $\mathrm{U}$

E.

E-1

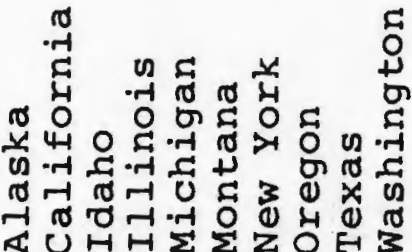

E

《UH 
The results of the breakbulk questionnaire are shown in Table XXVII. The response had a residual of $44,312.32$ tons and represented 26,418 of the breakbulk movement originally indicated as destined for Portland. The residual was allocated in the same manner as the above facility group response residuals.

CONCLUSIONS

In all the facility groups, export and import, the residual values were appropriated to the states in the responses by the percentage those states represented in each responding facility group. The most obvious measure of validity was the range of response, $22.21 \%$ to $100.00 \%$. However, the nature of the movement of the commodities making up each facility group is a measure of response representation. Therefore, the more complete the representation of the number of firms (those who direct movement) involved, the more representative of the population the response will be. Table XXVIII indicates the degree to which the response tonnage represented the number of firms. Thus, the three lowest facility groups, dry bulk (export), automobiles (import), and breakbulk (import), in terms of response tonnage, represented $67 \%, 50 \%$, and $44 \%$, respectively, of the firms sent questionnaires. The response, measured by percentage of total tonnage population or percentage of the firms sent questionnaires, was considered as 


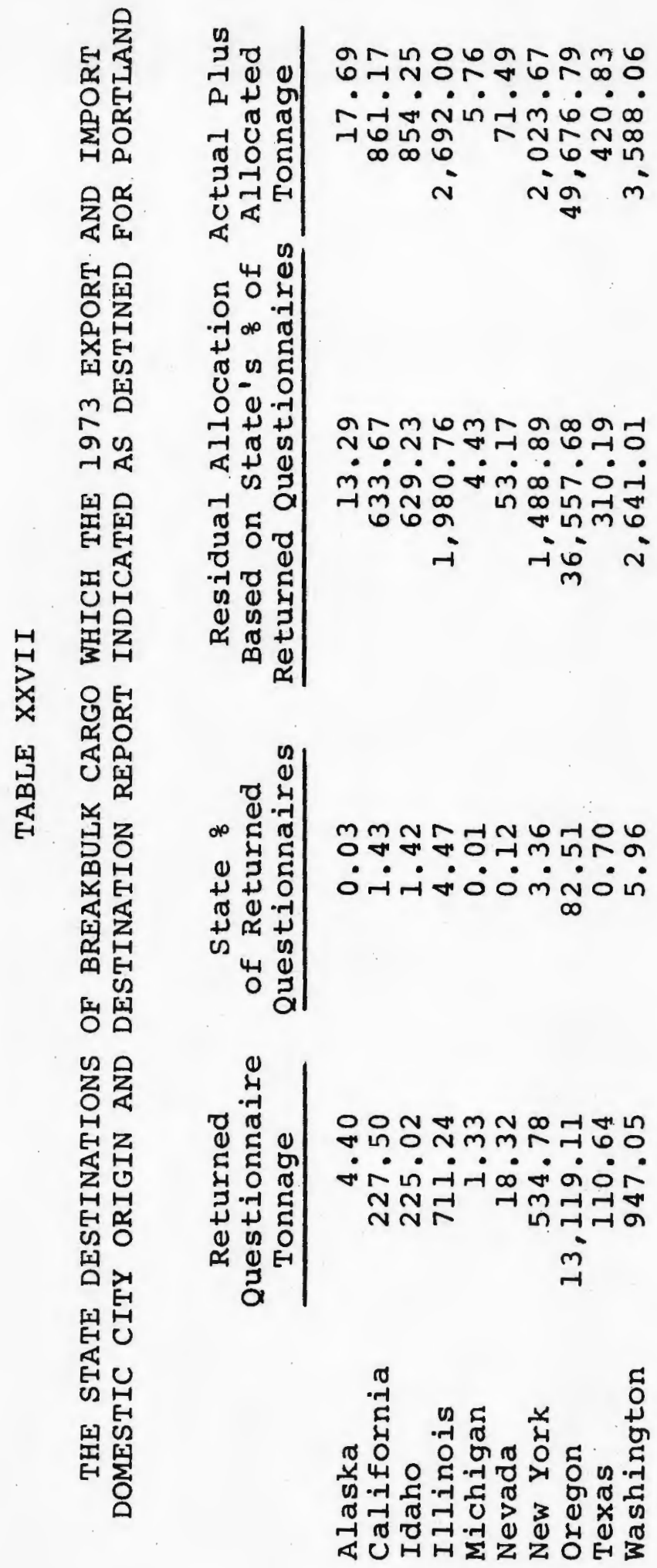




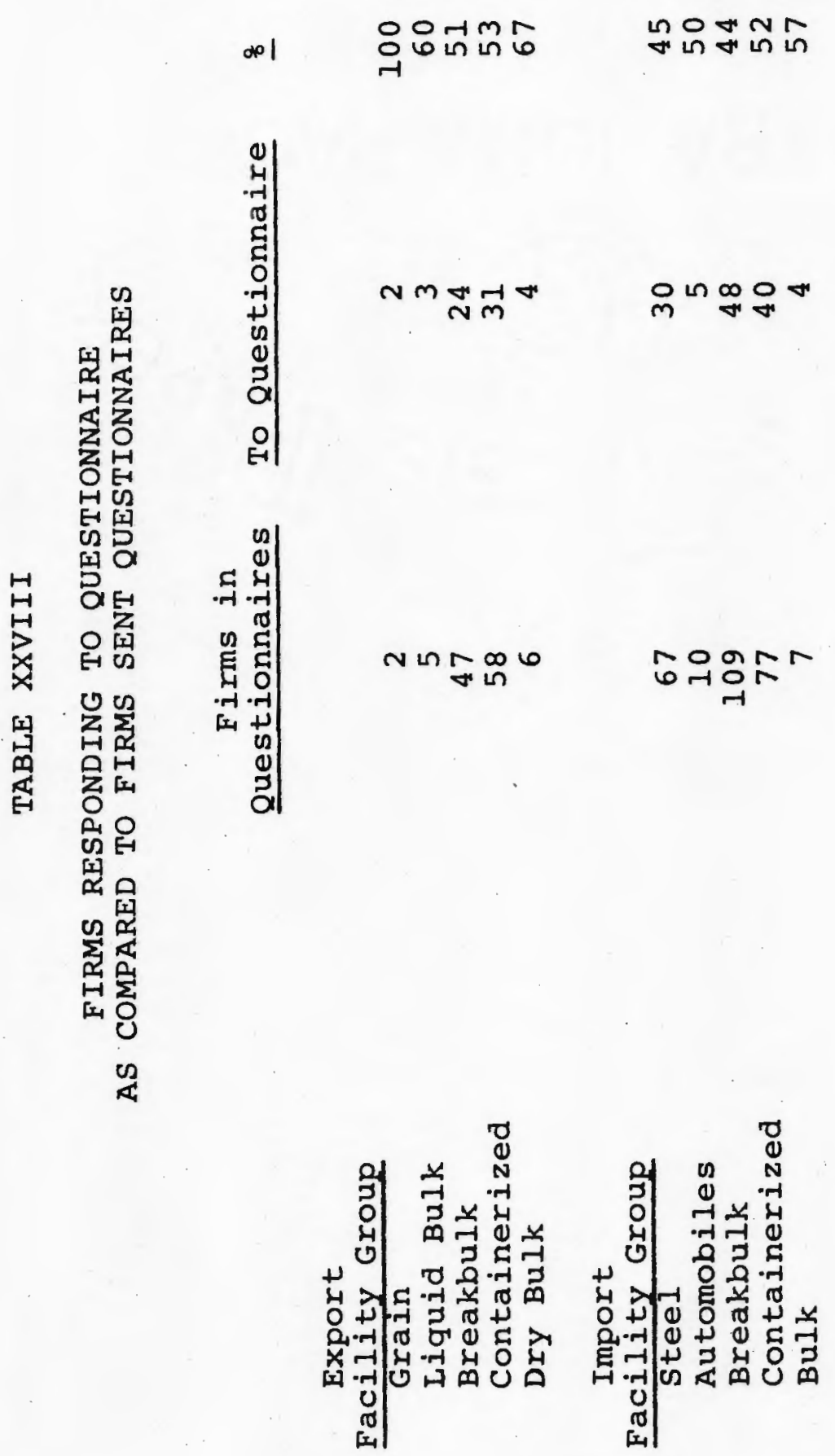


representative of the population at the state aggregation level.

Chapter V combines the original data (Chapter III) with the questionnaire response data presented in this chapter. The results will show the facility hinterlands of the Port of Portland. Recognizing the limitations inherent in a response of less than 1008 , the aggregate data will indicate an adequate representation of those hinterlands. 
CHAPTER V

THE PORT OF PORTLAND FACILITY HINTERLAND

The following hinterland analysis of the Port of Portland represents the aggregation of data collected from the 1973 Export and Import Domestic City origin and Destination Report Quarterly Reports (Chapter III) and the data from the questionnaires sent to Portland exporters and importers (Chapter IV). The data (tonnages) used to compile the figures shown here are presented in tabular form in Appendices $F$ (Exports) and $G$ (Imports). State totals were used rather than city totals due to a lack of city data in the returned questionnaires.

There were five basic principles that affected the flow patterns of Port of Portland facility hinterlands. They were complementarity, the friction of distance, the principle of least effort, intervening opportunity and comnodity sensitivity to transport costs. The friction of distance and commodity sensitivity to transport costs, while not synonymous, are both distance factors. Distance has a diluting effect on commodity flows. This effect is commonly referred to as the friction of distance, and states that an inverse relationship exists between commodity flow and distance. Some degree of distance decay was charac- 
teristic of the commodities making up the Port of Portland facility groups, however, the amount of friction exerted by distance varied with different commodity movements. Some movements, particularly low value commodities, are more sensitive to the friction of distance than others. Commodity sensitivity to movement is related to distance measured in transfer time and costs, and is largely a function of the value per unit weight of the commodity shipped. Generally, low value commodities move short distances, and high value commodities move longer distances. In the analysis of Port of Portland facility hinterlands, the friction of distance and commodity sensitivity to transport costs were combined into one factor because the effect each had on commodity flow was inseparable. The combined factor was referred to in this analysis as the transferability of a commodity. Thus, transferability represents the fact that commodity movement over space involves time and money costs varying with distance. The relationship between movement costs and distance gives rise to one of the other basic principles that affect commodity flow patterns; distance minimization.

Distance minimization was introduced in the social sciences by Zipf (1949). He referred to distance minimization as the "principle of least effort." In terms of the analysis of Port of Portland facility hinterlands, the 
principle of least effort means that it was assumed that commodity movement decisions were made to minimize costs. While it was recognized that decision makers in commodity movements were not always rational and did not always have adequate cost information, it was fair to assume that attempts were made to reduce the effect of distance as much as possible and that this behavior was an important factor in forming commodity flow patterns. The basic principle of intervening opportunity was allied to distance minimization (the principle of least effort). In commodity movements, intervening opportunity can be thought of as a way of reducing the movement costs associated with distance if the rate structure is favorable. Decision makers in commodity movements will ship goods through the port nearest the place of production (exports) or the place of consumption (imports). Due to the fact that the underlying philosophy of both intervening opportunity and the principle of least effort is the same; distance minimization, they were combined in the analysis of Port of Portland facility hinterlands and were referred to as simply intervening opportunity. The last of the five basic principles that affected the flow patterns of Port of Portland facility hinterlands, complementarity, concerns the conditions required for commodity movement between a point and its hinterland to take place. This concept states that commodity movement between the Port of Portland and its hinterland only took place 
when supplies of commodities existed at the Port of Portland, in the case of imports, and a demand for those commodities in the hinterland. The converse was the case for exports. The supply (production) of export commodities and the demand for (consumptionl import commodities in the hinterland was directly related to production and consumption patterns in the hinterland. The concept of the supply of import commodities and the demand for export commodities at the Port of Portland was less clear. Foreign export production and import consumption were obvious factors in the supply and demand for goods at the Port of Portland. The most important factor was the level of services and facilities offered. If no facilities were present to handle a specific commodity, then movement for that commodity did not occur. Petroleum provides an example of this. The Port of Portland does not own facilities for the import of petroleum products, therefore, none of this commodity moved through the Port of Portland. All petroleum products imported in Portland move through private facilities. The lack of particular facilities does not, however, concern the present analysis. The object here is to delineate the Port of Portland facility hinterlands based on commodity movement passing through existing facilities in 1973. The fact that commodities requiring specific facilities passed through the Port of Portland indicates the existence of those facilities. In this analysis, the supply of com- 
modities for the import facility groups was considered a given, and the demand for those commodities in the hinterland regulated magnitudes. The demand for export commodities at the Port of Portland from the hinterland was also considered as given since the facilities required for specific export movement exist. Thus, complementarity was measured as the demand for export goods provided the necessary facilities were ayailable, and the demand for import goods existed in the hinterland of commodities requiring available facilities.

Thus, the five basic factors of spatial interaction that effected the flow patterns of the Port of Portland were equivalent to UlIman's three-factor typology (1947); complementarity, transferability and intervening opportunity. The above simplification provides a concise and simplified analysis of the Portland facility hinterlands.

\section{EXPORTS}

The origins of total exports through the Port of Portland in 1973 were dominated by Oregon, Montana and Washington. These three states accounted for 78.488 of the exports with $35.18 \%, 22.908$ and 20.408 , respectively. The only other states accounting for more than 18 of exports were Colorado, Idaho, North Dakota, and Wyoming with 6.668 , $6.268,3.998$ and 2.298 , respectively. While export origins were indicated in thirty-six states, the above seven states 
provided $97.68 \%$ of the 1973 exports. This can be seen in Figure 3. The spatial compactness of the total export hinterland is quite evident. The concentration of origins is centered in the northwestern quadrant of the United states.

This concentration of flows was the result of the interplay of all three variables of spatial interaction. The localization of export flows was a reflection of the cost of movement and the importance of transferability in the whole interaction system of the Port of Portland's export origins. The other variables, complementarity and intervening opportunity, had a smaller impact than transferability. The demand for export goods (complementarity) was present in all ports and the existence of other ports (intervening opportunities) was obviously a factor. However, the decreases in the magnitude of tonnage with the increases in the distance of origins was most dominant. This generalization applies to the origins of total exports, however, it is not characteristic of all the export facility groups.

\section{Grain}

The spatial distribution of the origins of grain exports is represented in Figure 4. Oregon, Washington, and Montana, with $20.698,22.668$ and 32.698 , respectively, combine to account for 76.048 of the grain exported through the Port of Portland in 1973. The remaining states, Colorado, Idaho and North Dakota, each represented less than 


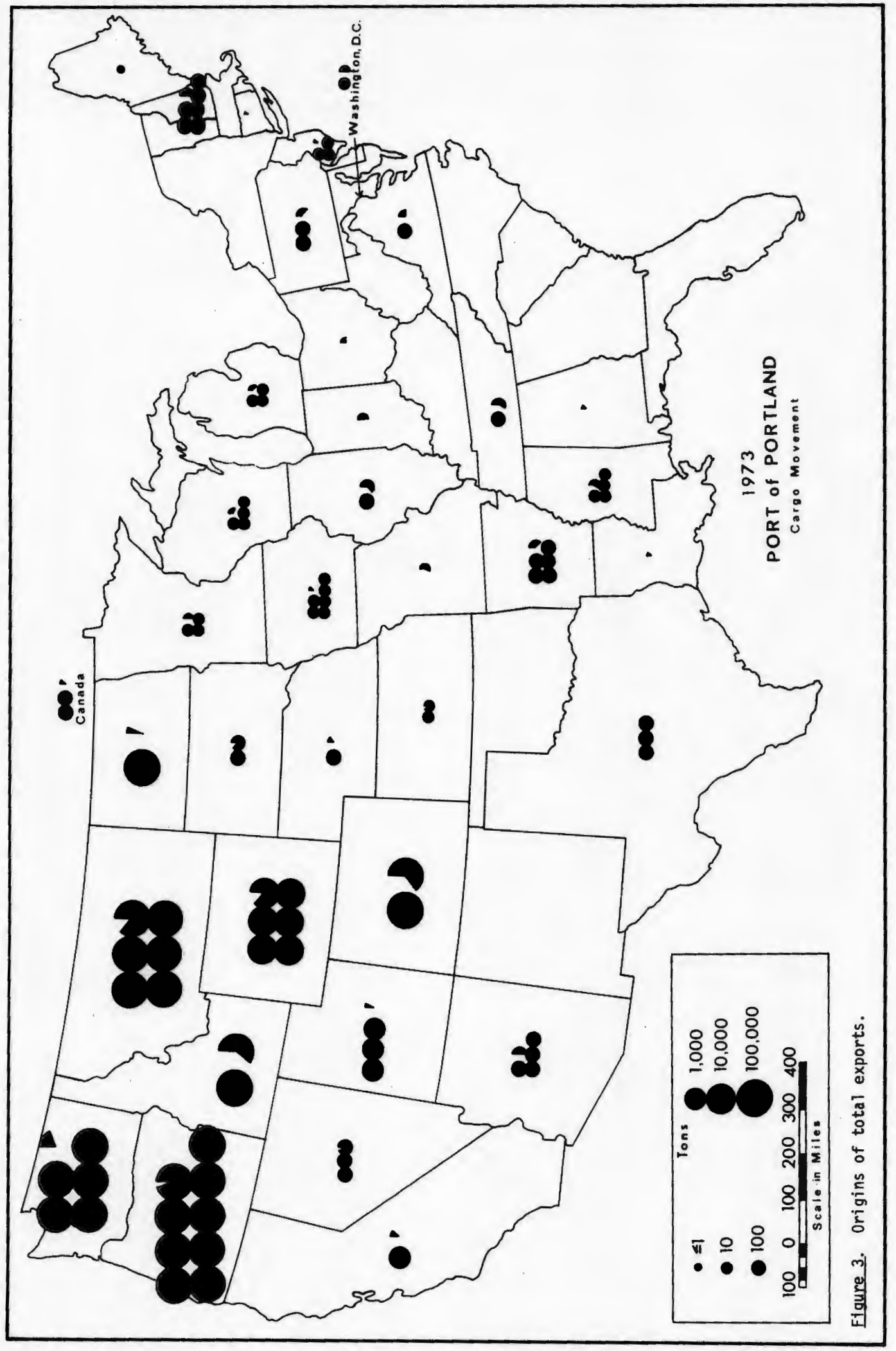




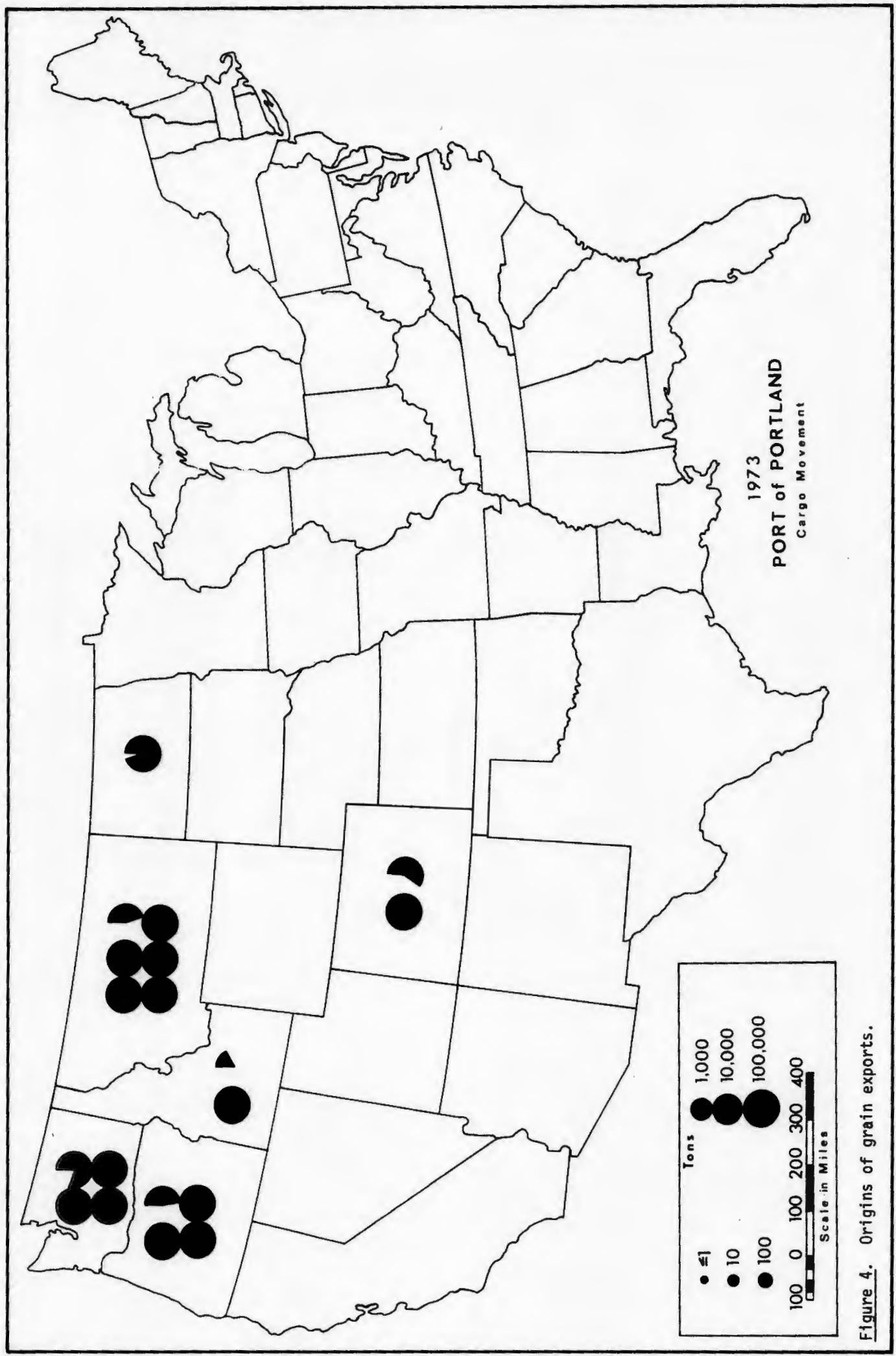


108 of the exported grain. The elements of complementarity, transferability and interyening opportunity were evident with grain flows, as with the flow of total exports. Grain is shipped in bulk form, and its value is relatively low per unit weight of shipment. The lack of grain shipped through Port of Portland facilities from the grain producing regions of the midwest can be attributed, primarily, to transferability. Grain from the midwestern United States can be moved over a shorter distance and at much less expense through the Mississippi River system to the Gulf of Mexico where grain export facilities are available. Grain export facilities are available at the Port of Portland and at the Gulf of Mexico (complementarity), but the existence of inexpensive river transportation over a shorter distance (transferability) and the presence of other export grain facilities (intervening opportunity) oriented the export grain flows from the midwest to the Gulf of Mexico. The existence of facilities for exporting grain at Seattle and Portland exerted the effect of complementarity on the grain producing northwest quadrant of the United States, as well as providing intervening opportunity. However, grain produced in the northwest can be shipped to the Port of Portland cheaper than to Seattle by using the Snake and Columbia Riyer systems (transferabilityl. So, while complementarity, intervening opportunity and transferability all effected grain flow simultane- 
ously, the sensitivity of grain to shipment costs (transferabilityl was the primary force in localizing grain flows, to the Port of Portland.

\section{Iiquid Bulk}

The flow pattern for liquid bulk was even more centralized than grain, with oregon representing $75.14 \%$ of the state origins. This can be seen in Figure 5. Washington, with 13.16\%, was the number two state of origin for liquid bulk exports, Montana and Idaho, with $3.79 \%$ and 3.05\%, respectively, were much less significant. This extreme localization of the flow pattern for liquid bulk is a further example of the effect of transferability. Liquid bulk commodities such as molasses, tall oil and tallow, which made up the entire export liquid bulk movement of the Port of Portland, were characterized by extremely high transport costs per value of unit volume moved. Sensitivity to transport costs not only localized the flow pattern of liquid bulk, but was also a factor contributing to the low tonnage; liquid bulk, with $23,262.85$ tons, was the lowest export facility group.

\section{Dry Bulk}

The dominant state of origin for dry bulk, in 1973, was Wyoming with 28.43\%. Oregon was a close second with 26.07\%, and Montana, Idaho, and Washington followed with $17.91 \%, 12.518$, and $11.06 \%$, respectively. 


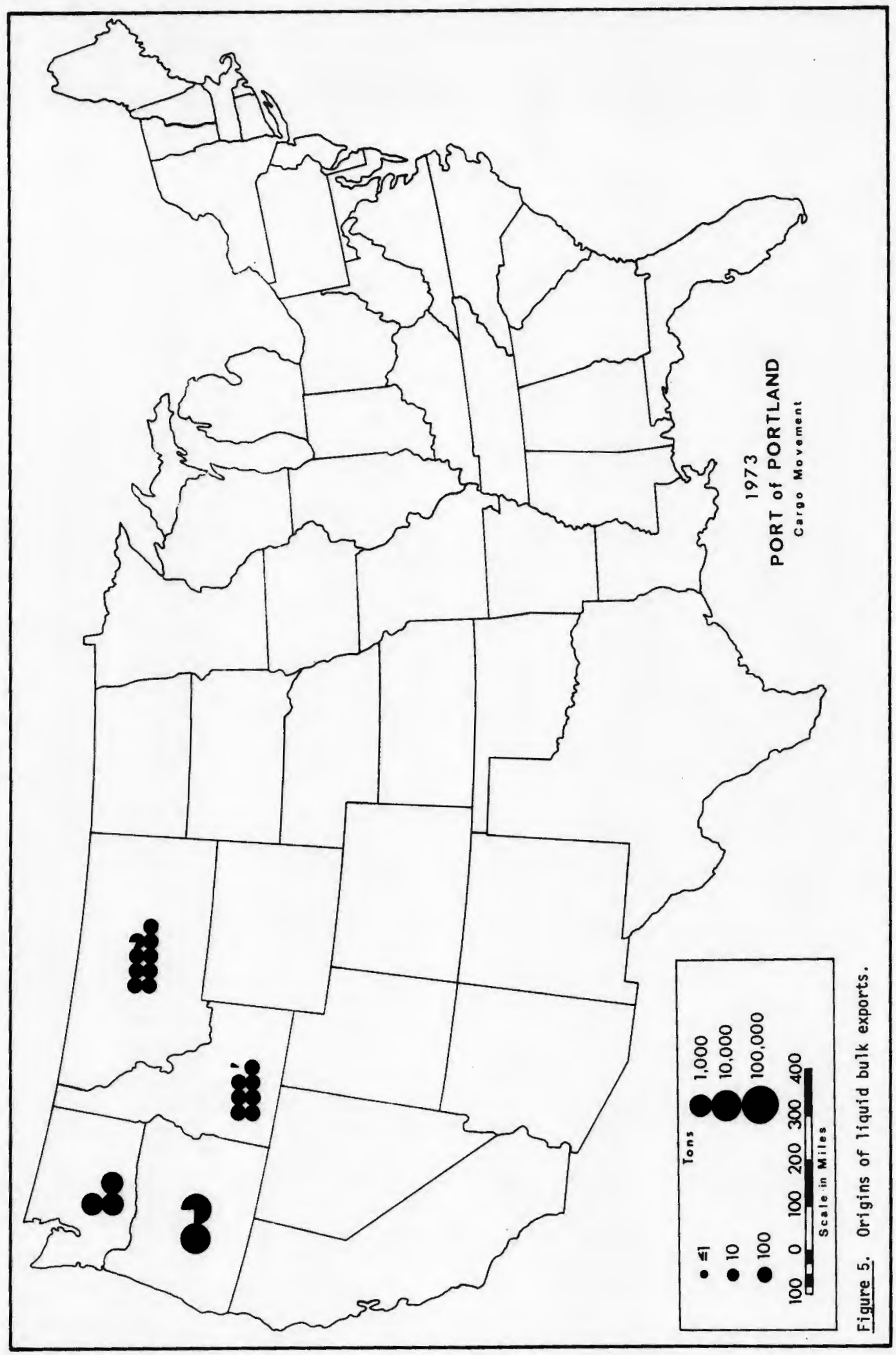


Figure 6 shows the spatial distribution of the origins of dry bulk. The flow pattern resembles that for grain, due primarily to the fact that the producing regions for the dry bulk commodities were in large part the same as those producing grain (sheat and barley). The variation that does exist between the dry bulk and grain hinterlands was caused by the inclusion of ores in the dry bulk facility group. The producing regions for ores vary from those for grain.

The sensitivity of ores to transport costs is at least as high as grain and other dry bulks. Ores are also characterized by a high weight loss in processing which causes industries who process ores to locate relatively close to the producing regions. However, the finished, or partially finished, product remains sensitive to high transport costs per unit of weight shipped. The factor of transferability was primarily the cause of the centralization of the dry bulk hinterland.

\section{Containerized}

The state origins of containerized cargo are represented in Figure 7. Oregon was again the major state of origin with 65.978 . Canada, Washington D.C., and the remaining 25 origin states accounted for less than 18 each of the containerized exports, except Washington and Idaho. The latter states were the origins for $20.30 \%$ and $4.33 \%$, respectively, of the containerized exports. Only Arizona, 


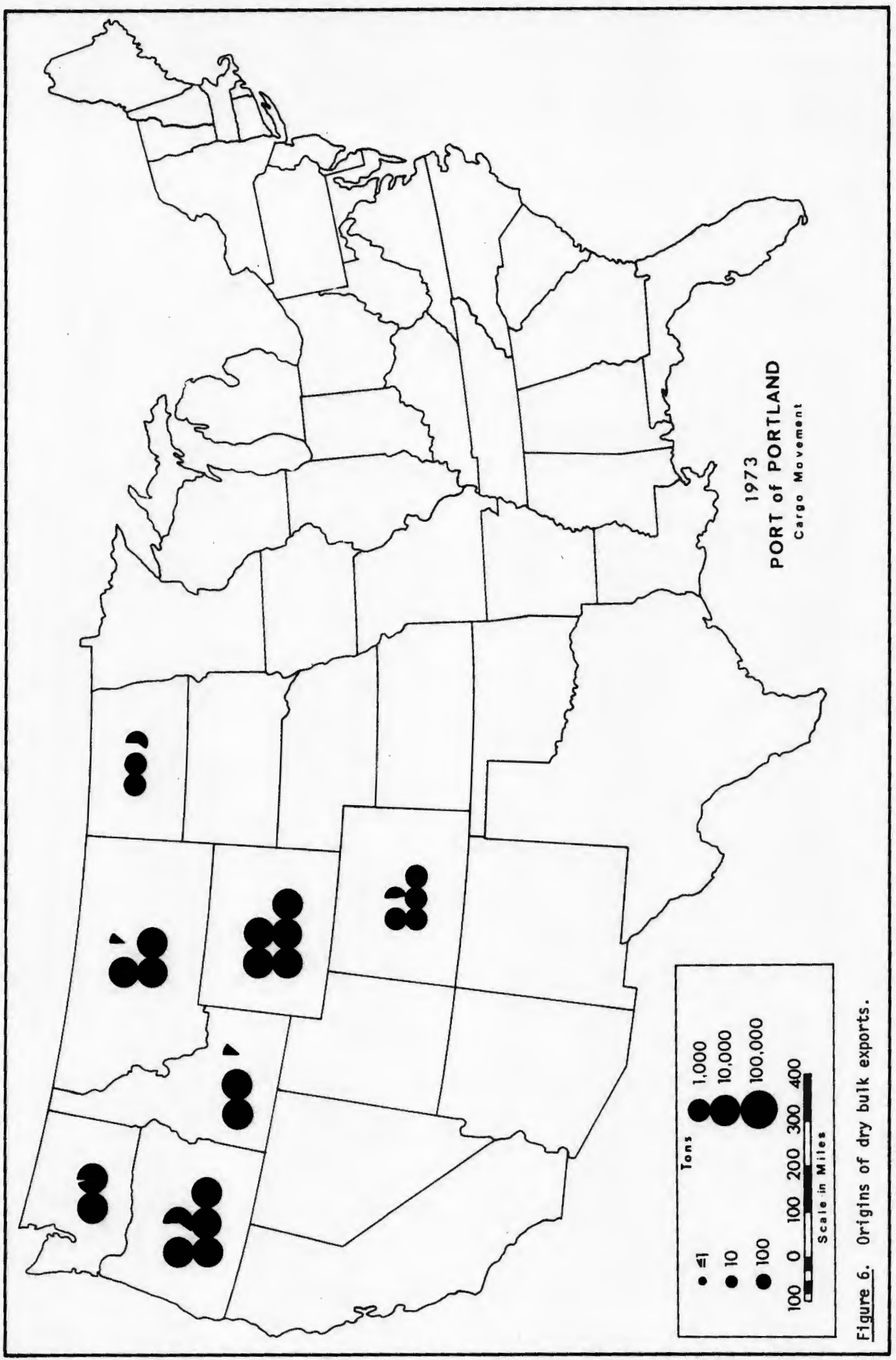




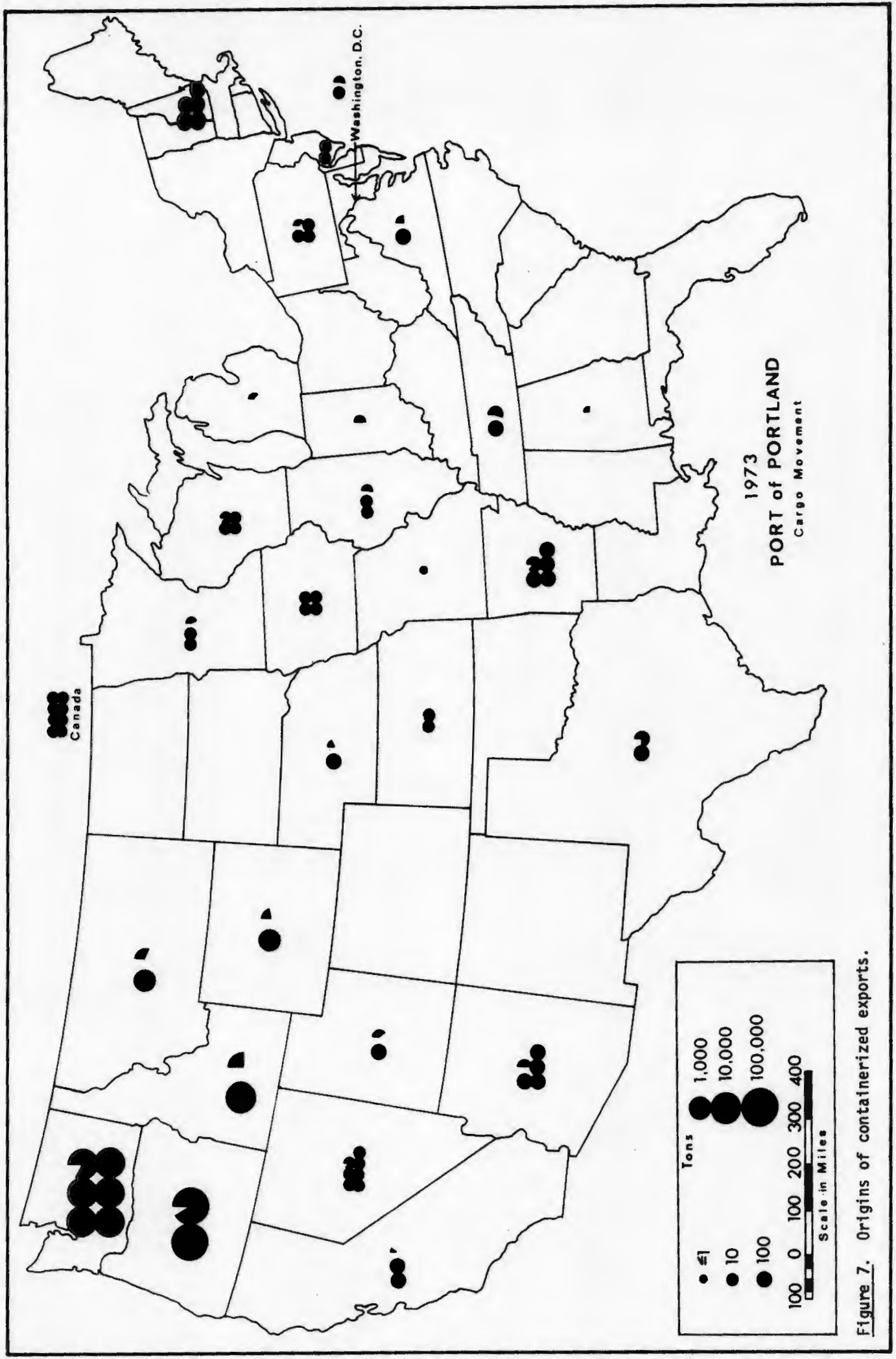


Arkansas, and New Hampshire accounted for more than 0.18 of the cargo outside the northwestern quadrant of the United States. The total tonnage for these three states, 1,442.73, amounted to a combined $0.5 \%$ of the total movement.

The major effect of transferability was evident for containerized cargo with $86.27 \%$ of the origins in oregon and Washington. In the case of containerized cargo, however, it was the friction of distance rather than shipment cost sensitivity which was the major factor. Containerized cargo, in general, is of higher value per unit shipped than commodities shipped in bulk and can experience higher transport costs and still remain competitive. The supply of containerized cargo (complementarity) and intervening opportunity were more important factors effecting containerized flows than they were with the bulks. The producing region of the many and varied commodities comprising containerized cargo included the entire United States. The facilities for handling containerized cargo require a large capital expenditure by ports, however, virtually all united States export ports have the necessary facilities because they want the revenue generated by movement of containerized cargo (more revenue per ton moved is generated by containerized cargo than with bulk movement). The supply of containerized cargo was dispersed over the entire United States and ayailability of containerized facilities 
(representing demand by portsl was present at all ports. Thus, while transferability localized the flow pattern of export containerized cargo around the Port of Portland, complementarity tended to regionalize and nationalize the flow pattern. The factor of intervening opportunity lother export ports closer to the individual producing areas) worked with transferability in localizing the flow pattern, and thus diminished the effect of complementarity.

Breakbulk

The flow pattern for breakbulk was very similar to that for containerized cargo. The breakbulk pattern is shown in Figure 8 . Oregon was more dominant in the breakbulk facility group origins, accounting for 77.298 . Like the containerized facility group, Washington and Idaho were second and third with $15.30 \%$ and 2.228 , respectively, of the total movement. However, a greater percentage of breakbulk cargo originated outside the northwestern quadrant of the United States than of containerized cargo.

The value of breakbulk cargo is higher per unit of shipped weight, as with containerized cargo, than bulk cargo. Thus, transferability had the same effect on breakbulk cargo as containerized cargo, somewhat less of an effect than with the bulks in localizing flows. A dispersed producing area (supply) and the ayailability of breakbulk facilities at all ports (demand) is characteristic of breakbulk, as was the case with containerized cargo. The effect of comple- 


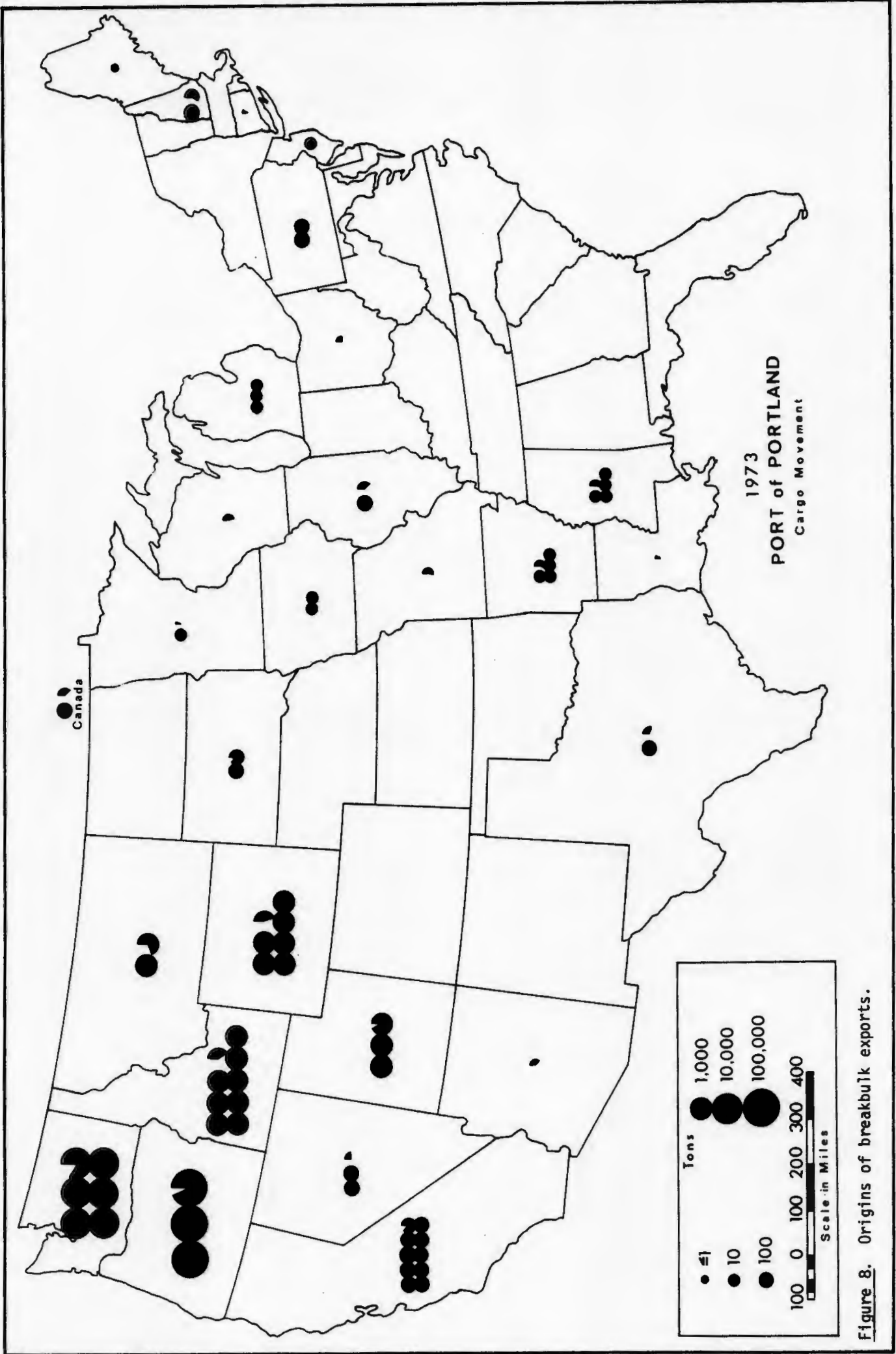


mentarity (the supply and demand factorl was responsible for the expanded spatial distribution of the origins of breakbulk, as with the containerized facility group. The effect of intervening opportunity on breakbulk flows was less than with containerized cargo, as evidenced by the higher percentage of breakbulk tonnage originating outside the northwest quadrant of the United States. This is not readily explanable from the data used here. A probable explanation, however, might be the ultimate port destination of the cargo. Containerization is an innovation of the recent past and many ports, foreign and domestic, do not have adequate containerization handling facilities. Thus, non-bulk cargo destined for those ports must be shipped in breakbulk form rather than in containers from a port that has steamship service to breakbulk foreign ports. However, to establish this as the cause of the smaller effect of intervening opportunity on breakbulk cargo would require analysis of the foreign destination hinterlands of the Port of Portland combined with a look at the steamship service capabilities.

\section{IMPORTS}

The destinations of total imports through the Port of Portland were dominated by Oregon. That state was the destination for 78.888 of the imports. Washington was a distant second with 12.768 of the imports, as shown in 
Figure 9. While import destinations, in percentage terms, were greater in Oregon than were export origins, the imports did not present as compact a hinterland. A concentration of import flow was evident in Oregon, Washington, and Idaho, however, import flows measured in percentages were greater throughout the United States than with the export flows, and represents a shift in importance of the elements of the three-factor typology. Complementarity (domestic demand) for imported goods is directly related to population. The extended flow pattern tended to be oriented toward major population states, i.e., California, Illinois, and New York. Thus, transferability caused a primary import hinterland in close proximity to the Port of Portland, and complementarity created a discontinuous as well as secondary hinterland in varying stages throughout the United States to a greater extent than with exports. Intervening opportunity in import facility hinterlands was represented by the existence of other ports with the same facilities, and tended to localize the import flow pattern, as with transferability. This generalization of the effects of the three factors does not pertain uniformly to all the import facility groups.

Bulk

Figure 10 indicates the extent of the import bulk hinterland. The primary nature of this hinterland is obvious. Oregon was the destination for 89.958 of the bulk 


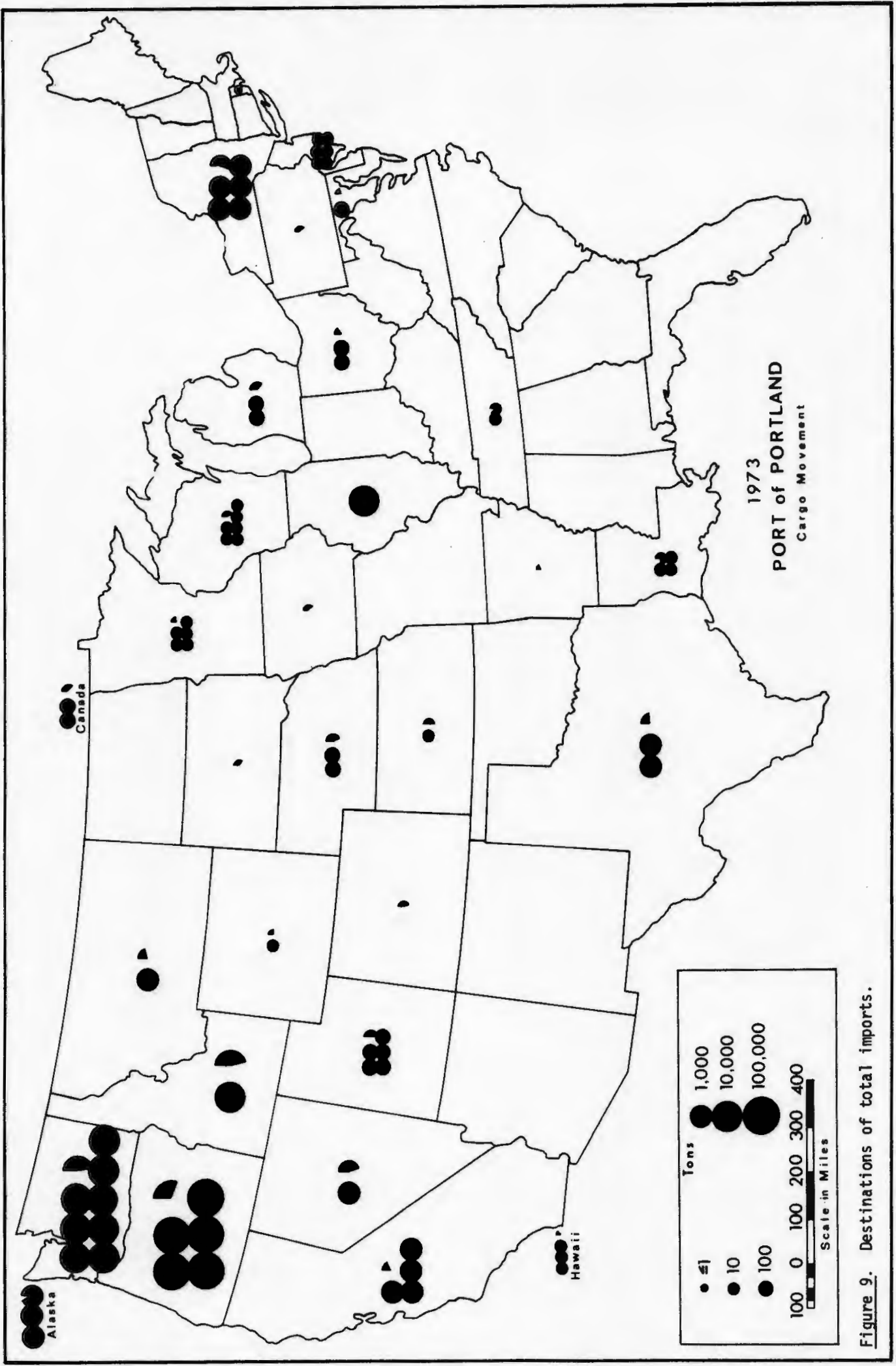




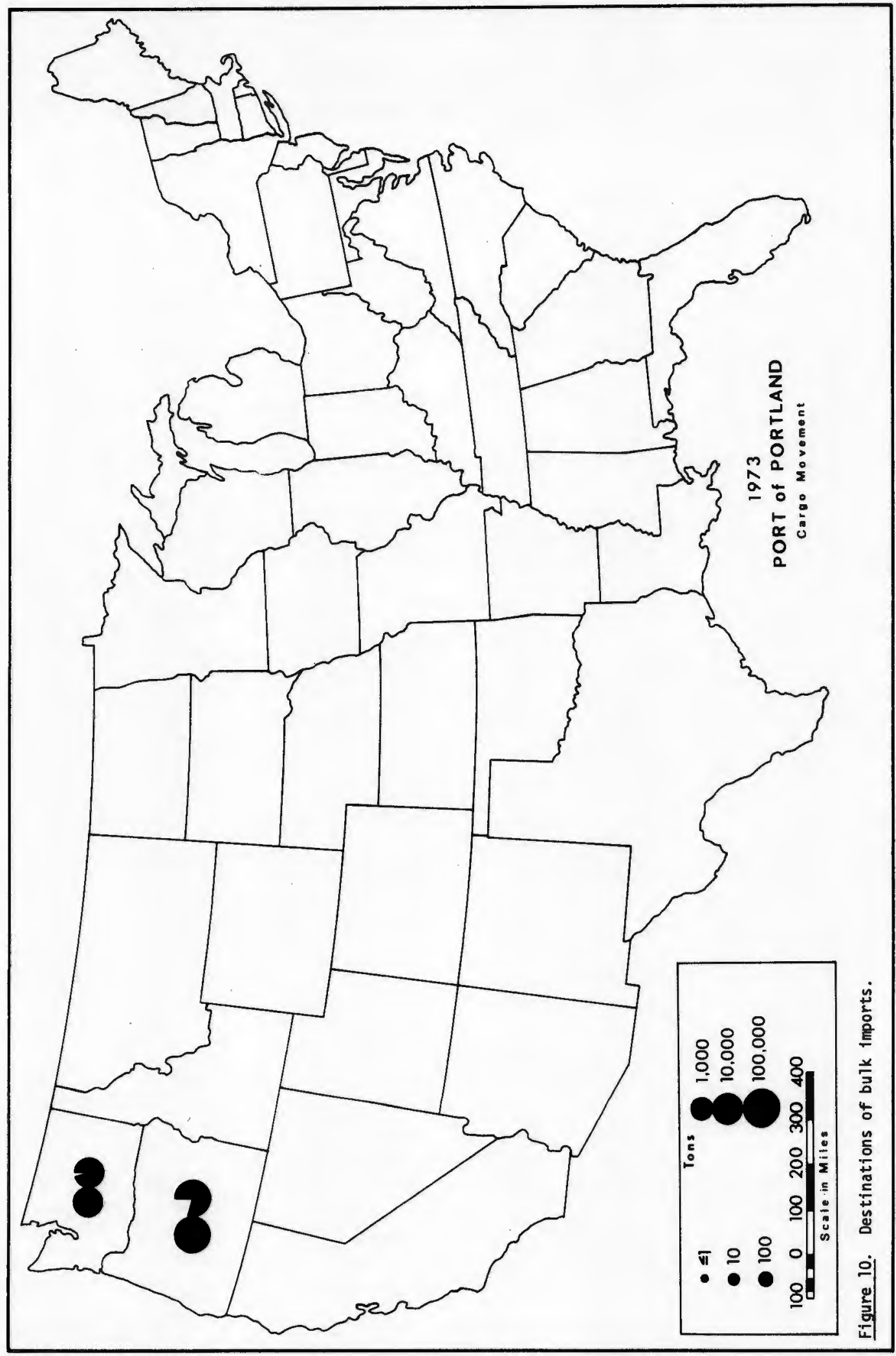


imports. Washington was much less important, but was the only other state of destination of bulk imports. The supply of bulk imports was assumed to be a given because the availability of bulk off-loading facilities at the Port of Portland was indicated by the fact that import bulk movement took place at all. However, while complementarity (supply and demand) was a factor in influencing import bulk destinations, the bulk imports were strongly influenced by transferability. The reason for this is the same as it was for the export bulks. That is, the extreme sensitivity to transport costs of bulk cargo of relatively low value per unit of weight shipped. The existence of other ports, intervening opportunity, and bulk commodity sensitivity to transport costs, transferability, were the dominant factors in localizing bulk import flows and producing a compact primary hinterland around the Port of Portland.

\section{Automobiles}

The import hinterland for automobiles is indicated in Figure 11, Washington, Oregon, and Idaho had 46.65\%, 33.408, and 11.868 , respectively, of the total imported automobiles. The primary factor was the distribution system of the import automobile dealers, with complementarity, transferability, and interyening opportunity assuming a lesser degree of direct importance.

The importance of the three factors' influence on the 


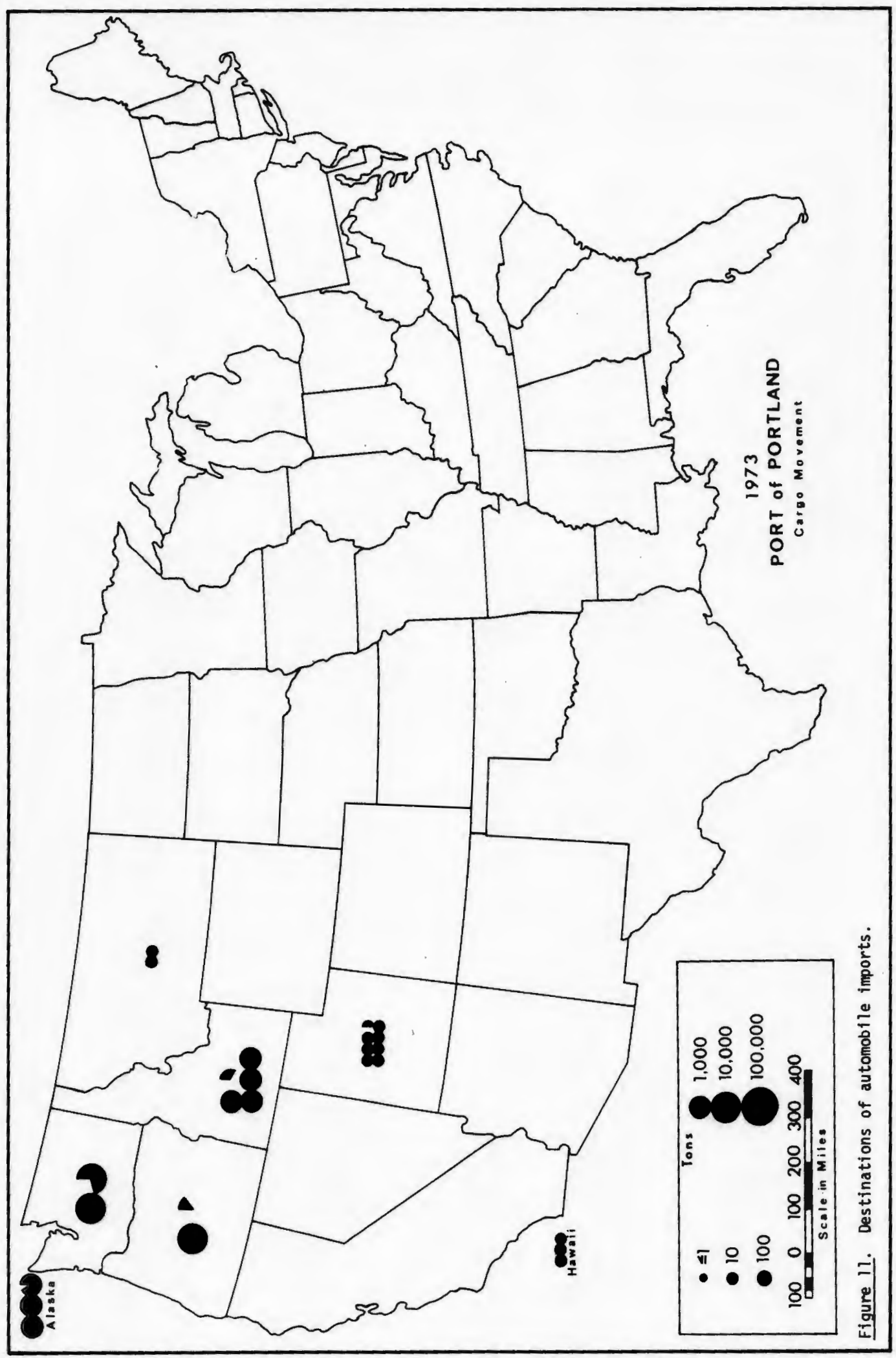


flow pattern of automobiles was indirectly related to the distribution system. The dealers who imported automobiles through Port of Portland facilities did so because of prearranged agreements, steamship service capabilities, and existing facilities owned or leased by them. Conditions of competition and contractual agreements largely negated any effects of intervening opportunity. Therefore, the quantity of automobiles imported in Portland as opposed to other ports was decided by market conditions in the United States for the particular automobiles handled by those dealers. The effect of transferability on the import automobile flow, within the existing distribution system, was evident, however, by the localization of the flow pattern. The high value per unit shipped of automobiles tended to negate transport cost sensitivity. The friction of distance was the prime factor in the centralization of flows. Complementarity, in the form of Port of Portland facilities (supply) and population demand, was evident by the fact that Washington, a more populous state, was the destination for more automobiles than Oregon. Facilities existing elsewhere were not necessarily factors of complementarity due to the distribution system. The indirect shipments to Alaska, as opposed to direct shipments to Alaskan ports, was the result of the existing distribution system.

Steel

The flow pattern for import steel is shown in Figure 
12. Oregon was the destination for $85.58 \%$ of the imported steel, while Washington and Idaho accounted for 7.928 and $2.41 \%$, respectively. Transferability is reflected in the primary hinterland exemplified by steel.

Complementarity was a factor in import steel flows in the form of domestic population (demand) and import steel facilities being present. However, intervening opportunity (the availability of import steel facilities at ports closer to steel consuming areas) combined with transferability to negate the complementarity existing between the Port of Portland and areas closer to other ports. This generalized statement did not hold for shipments to major population states such as California, Illinois, and New York. The reason for these exceptions is not apparent from the data. Steel is a heavy commodity sensitive to transport costs, as were the export and import bulks. However, the importance of cost sensitivity to movement is somewhat less than with bulks because the value of steel per unit shipped is greater. A possible explanation accounting for the extended flow pattern of steel might be the location of the customers of steel importers in Portland. The lesser sensitivity of steel to movement might allow shipments over longer distances to particular customers.

Containerized

The importance of complementarity and intervening opportunity in the spatial extent of import hinterlands was 


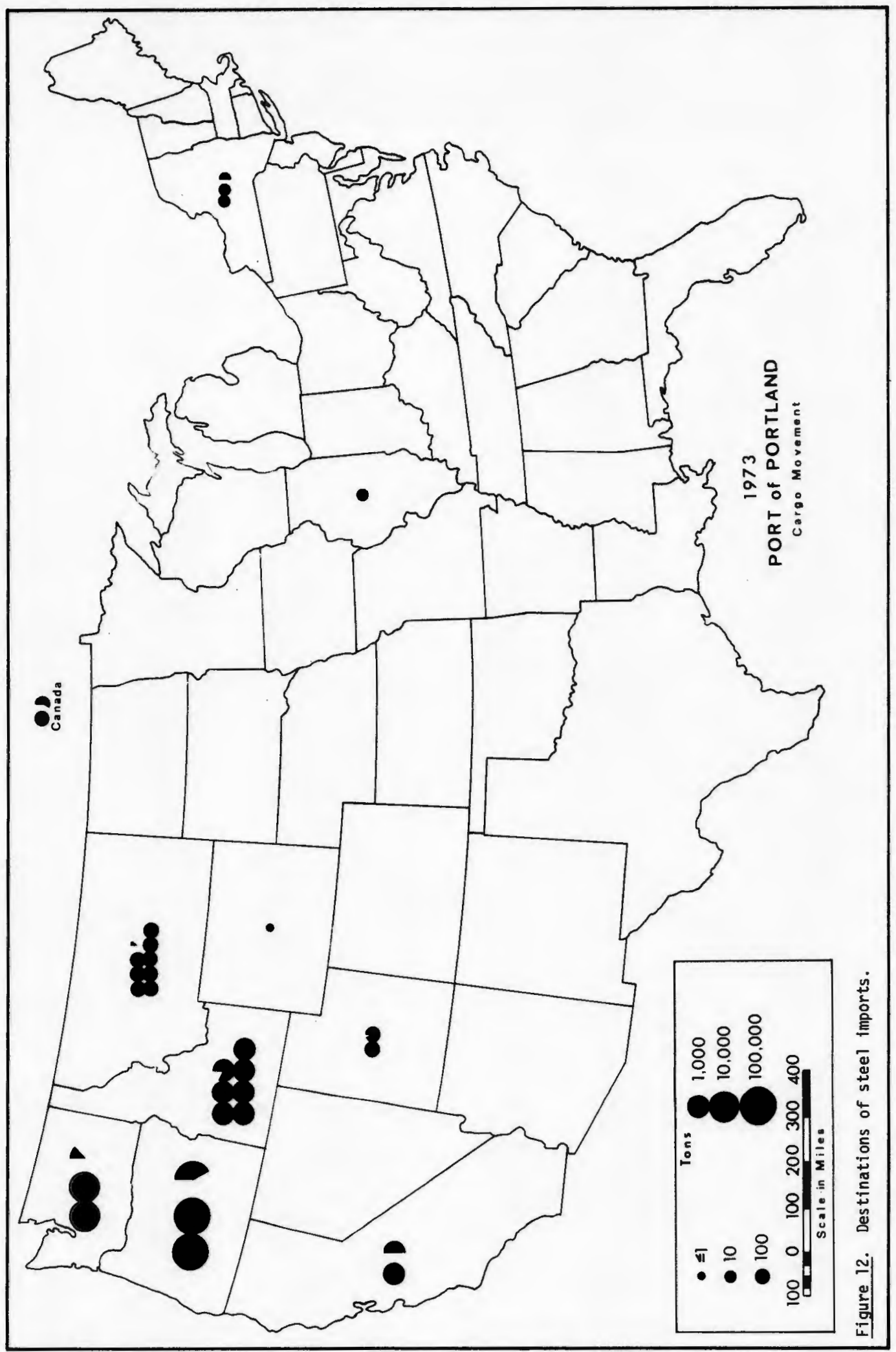


quite evident in the import containerized cargo hinterland. A primary hinterland was evident in Oregon, which was the result of the friction of distance, or transferability. As with export containerized cargo, the import containerized cargo was generally high in value per unit of weight, thus negating transport cost sensitivity to a large degree. While Oregon was the destination for $55.05 \%$ of the containerized imports, California, Illinois and New York accounted for 20.478 of the total containerized imports, as shown in Figure 13. Washington represented a fringe area of the primary hinterland (Oregon) with only 18.128 of the containerized imports destined for that state.

Complementarity existed in the hinterland in the form a demand related to major population areas. The supply of facilities for handling import containerized cargo was present at all major ports. This universal supply and the friction of distance combined to provide the influence of intervening opportunity. With larger populations, it was assumed that California and Washington would demand more imported goods than oregon, yet their respective tonnages are smaller than in oregon. The reason is the fact that the imported containerized cargo destined for those other areas came from closer ports such as the Port of Seattle, the Port of Oakland and the Port of Los Angeles/Long Beach.

Another factor was present in the flow of imported 


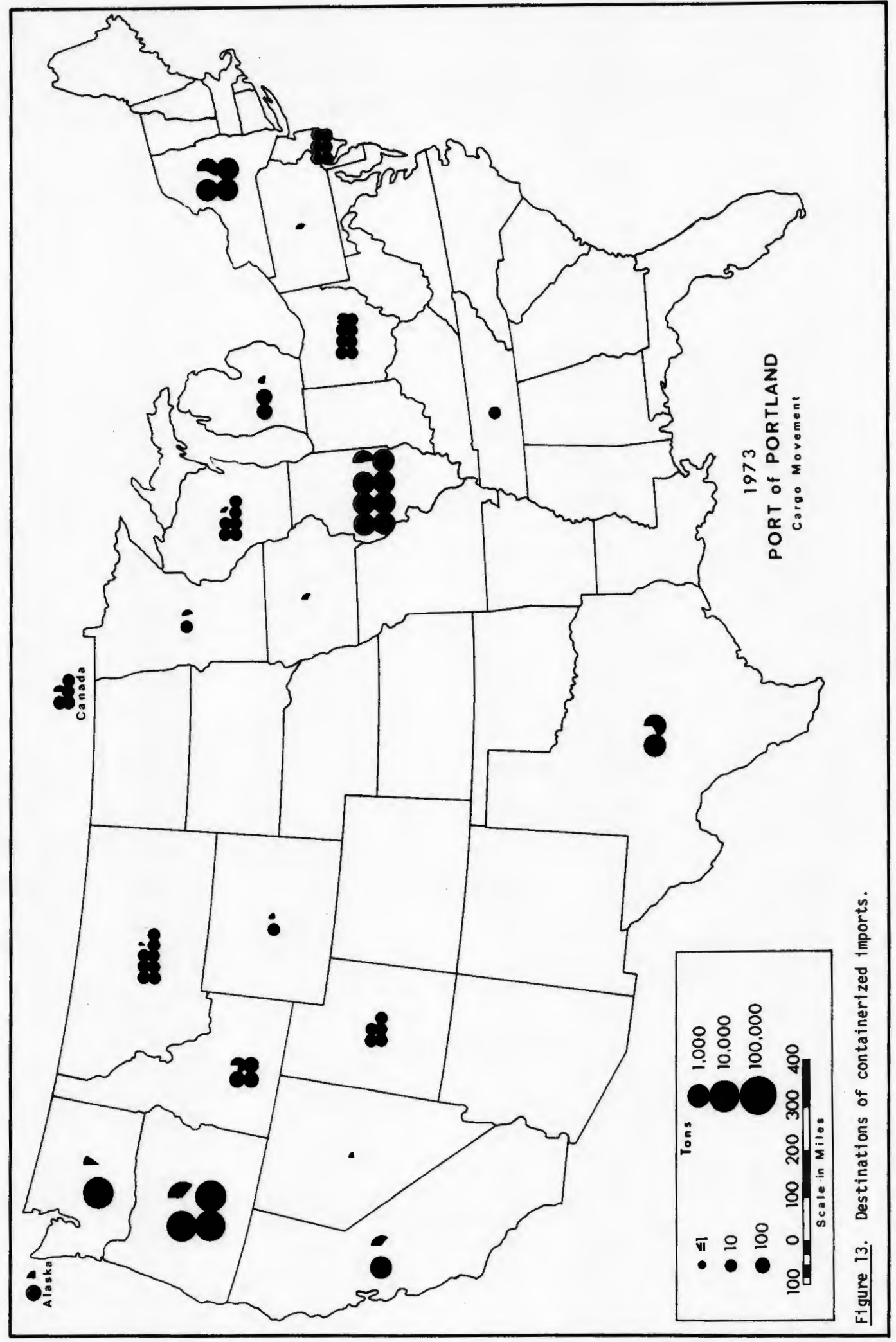


containerized cargo: the "Overland Common Point" (OCP) cargo freight rate. Basically, OCP means that certain cargo destined for any point east of a north/south line bisecting Denver, Colorado, is shipped at the same rate from any of the West Coast ports. OCP cargo was mostly containerized and breakbulk cargo. The effect that OCP cargo rates had on containerized imports at the Port of Portland was to increase the importance of complementarity (population demand) at the expense of transferability for eastbound cargo. This was evidenced by the shipments to such states as Texas, Illinois, Ohio and New York.

\section{Breakbulk}

The breakbulk import flow was similar to that of containerized imports as depicted in Figure 14. Oregon represented a stronger primary hinterland with 68.608 of the breakbulk imports destined for areas within its borders; a direct result of transferability (the friction of distance rather than sensitivity to transport costs). Complementarity, like containerized imports, was present between the hinterland (demand) and all ports (supply). The facilities for handling breakbulk cargo were available universally. Thus, transferability (the friction of distance) and complementarity provided increased opportunities for imported breakbulk cargo to move through other ports. The smaller movement from the Port of Portland to Washington and California was the result of intervening 


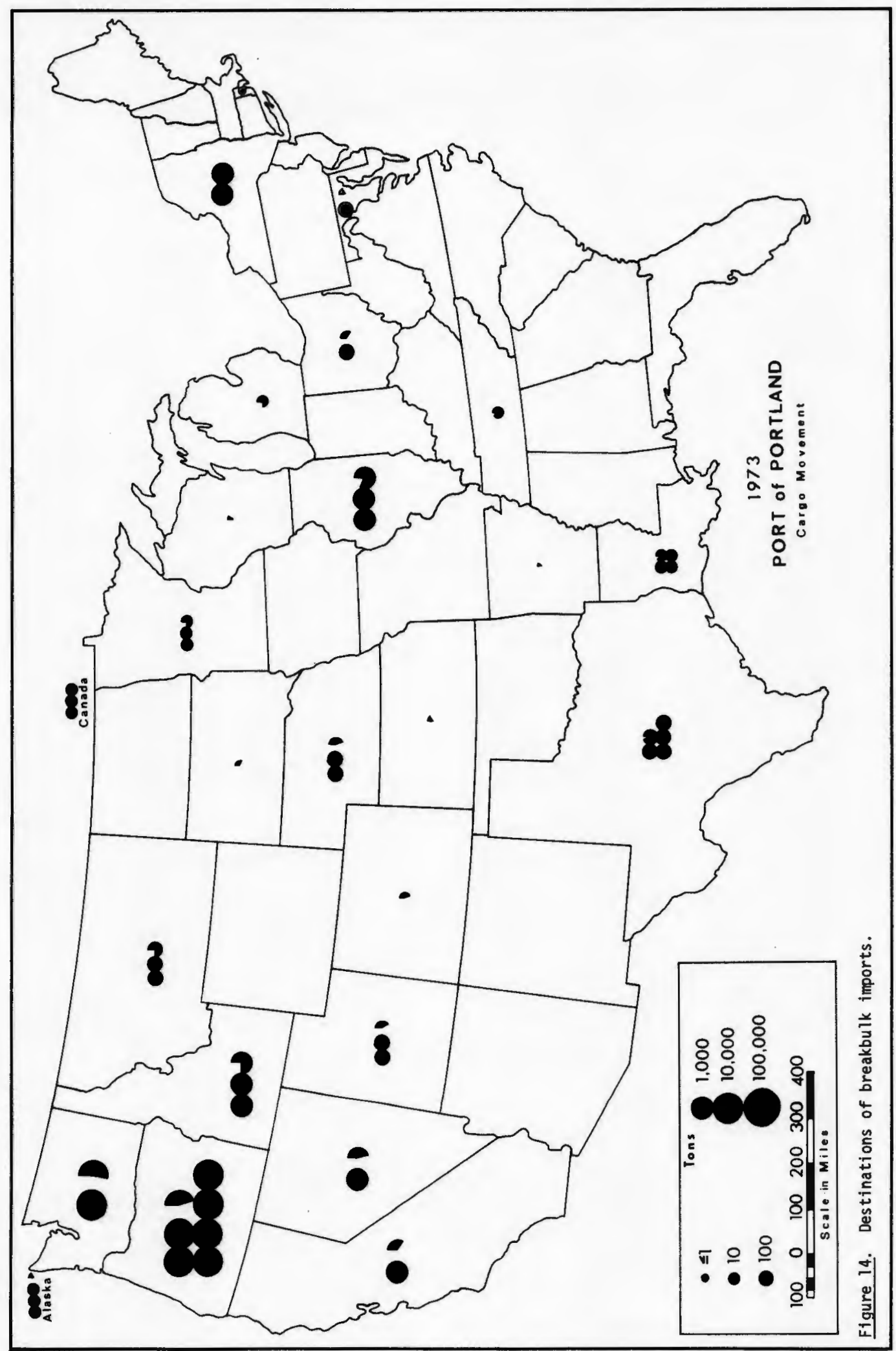


opportunities.

OCP rates (discussed in containerized cargo section above) had a smaller effect on breakbulk imports than on containerized imports, as evidenced by smaller tonnages shipped eastbound. The increase in the localization of import breakbulk flows as compared to import containerized flows was not completely explainable from the data. The cause may have stemmed from the level of steamship service alluded to above for export breakbulk. The foreign countries exporting breakbulk cargo destined for the United States may have been constrained by limited breakbulk steamship service. Also, the effect of OCP rates may have been less on breakbulk than containerized cargo because the quantity of OCP breakbulk cargo has been decreasing in the past few years. More and more OCP cargo has been shipped in containers because of the increase in ease of handling and the decrease in damage resulting from containerized movement.

\section{CONCLUSIONS}

\section{Exports}

The nature of the export hinterlands varied with the nature of the facility group. The scope of this study does not permit the analysis of secondary hinterlands because of the domestic origins of exports passing through other ports was not delineated. It was assumed, however, 
that overlapping hinterlands theoretically existed, to varying degrees, throughout the United States. It was possible to identify primary and discontinuous hinterlands, from the Port of Portland's perspective, within the scope of this study.

Containerized and breakbulk cargo was characterized by a primary hinterland in the states surrounding the Port of Portland and, following the assumption above, a secondary hinterland existed throughout the United states. The primary hinterlands of these two facility groups tended to decrease with distance while the secondary hinterland did not. The evidence of a secondary hinterland for containerized and breakbulk cargo was directly attributed to the factor of complementarity (availability of necessary facilities at other ports). The relatively small magnitude of the secondary hinterland was the result of the effect of intervening opportunity. The major factor in producing the localization of flows of containerized and breakbulk cargo into a primary hinterland was transferability. However, with these two facility groups, the friction of distance appeared to be more important to restricting the flows over distance than sensitivity to transport costs due to the generally higher value of containerized and breakbulk cargo.

The liquid bulk facility group represented a primary hinterland centered in Oregon, decreasing in importance 
through Washington, Idaho, and Montana. Grain and dry bulk were each represented by a primary hinterland, oregon and Washington. The supply factor (complementarity) is partially responsible for localization of flows. This was due to the location of the producing regions of the commodities that make up the grain and dry bulk facility groups, and facility availability. The primary factor responsible for producing the localization of flows in the bulk facility groups was transferability. Unlike containerized and breakbulk cargo, however, the sensitivity to transport costs was paramount for bulks.

In general terms, the three-factor typology fitted the flow of export goods from domestic origins, through the Port of Portland, to foreign destinations. Complementarity, transferability, and intervening opportunity, each represented factors making the northwestern quadrant of the United States the Port of Portland's export hinterland, with transferability generally most important. Oregon, Washington, Idaho, Montana, and Wyoming made up the heart of this hinterland to varying degrees generally correlated to distance. The states bordering the hinterland tended to be less important than those in the hinterland, but more important than even more distant states.

\section{Imports}

As with exports, the nature of the import facility hinterlands varied with the nature of the facility group. 
The three-factor typology played an important role in the flows making up the import hinterlands, but in a slightly different way than with exports.

All of the import facility groups exhibited a primary hinterland centered on Oregon and Washington, which was a direct result of the effect of transferability. This manifested itself as sensitivity to transport costs for bulk and steel, and the friction of distance for automobiles, containerized and breakbulk cargo. The factor of complementarity was largely negated by transferability and intervening opportunity in the case of bulk and steel flows. The existence of a set distribution system provided an increased importance of complementarity in import automobile flows. The existence of OCP cargo rates and the relatively high value per unit shipped of containerized and breakbulk cargo extended the flows of those to facility groups.

In general the three-factor typology fitted the flow of import goods from the Port of Portland to domestic destinations. The three factors combined to make the Port of Portland's import hinterland primarily located in Oregon and Washington. However, complementarity, due to the exogenous factors of OCP rates for containerized and breakbulk cargo and an already existing distribution system for automobiles, provided a basis for extended commodity flow in terms of distance and magnitudes. 
It is not suggested that complementarity, transferability and intervening opportunity were the only factors involved in export and import commodity flows. The factors are actually many and varied, as is necessarily the case in an economic system as deversified and complex as that of the United States. What is suggested is that an understanding of the interaction of the three factors within the economic system explained a good deal of the export and import commodity flow of the Port of Portland, and thus its hinterlands. 


\section{SELECTED BIBLIOGRAPHY}

Alexander, John W., 1963, Economic Geography, Englewood Cliffs, New Jersey: Prentice-Hall, Inc.

, S. Earl Brown and Richard E. Dahlberg, 1967. "Freight Rates: Selected Aspects of Uniform and Nodal Regions," Readings in Economic Geography, Reopke, Howard G., ed. New York: John Wiley and Sons, Inc.

Berkis, Andrejs Krisjanis, 1968. The Competitive Advantages of Portland and seattle in the Foreign Maritime Trade of the pacific Northwest. Unpublished master's thesis in Geography, Western Washington State College.

Berry, Brian J. L., 1967. Geography of Market Centers and

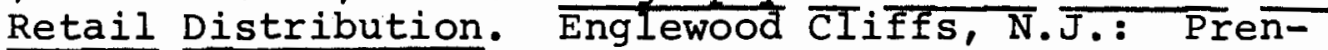
tice-Hall, Inc.

1 1970. "Recent Studies Concerning the Role of Transportation in the Space Economy," Economic Geography: Selected Readings. Dohrs, Fred E. and Iawrence M. Sommers, eds. New York: Thomas Y. Crowell Company.

, and Allan Pred, 1968. "Walter Christaller's Die Zentralen orte in süddeutschland Abstract of Theoretical Parts," Readings in Economic Geography: The Location of Economic Activity, Smith, Robert H.T., Rand McNally and Company.

Boerman, W. R., 1952. "The Need for Special Examination of Particular Aspects of Port Geography," Preliminary Report of the Commission on Industrial ports, New York: International Geographical Union.

Carter, Richard E., April, 1962. "A Comparative Analysis of United States Ports and Their Traffic Characteristics," Economic Geography, 31, pp. 162-175.

Chisholm, Michael, 1968. "Johann Heinrich von Thünen," Readings in Economic Geography: The Location of Economic Activity, Smith, Robert $\bar{H} . T .$, Edward J. Taaffe and Leslie J. King, eds. Chicago: Rand McNally and Company. 
Christaller, Walter, 1966. Central Places in Southern Germany, translation by C. W. Baskin, Englewood Cliffs, New Jersey: Prentice-Hall, Inc.

Daggett, Stuart, 1968. "The System of Alfred Weber," Readings in Economic Geography: The Location of

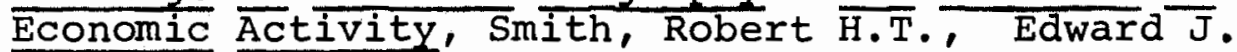
Taaffe and Leslie J. King, eds. Chicago: Rand McNally and Company.

Draine, Edwin H., 1963. Import Traffic of Chicago and its Hinterland. Department of Geography Research $\overline{\text { Paper }}$ No. 81. Chicago: The University of Chicago.

Dunn, Edgar S., 1968. "The Equilibrium of Land-Use Patterns in Agriculture," Readings in Economic Geography: The Location of Economic Activity, Smith, Robert H. T. , Edward J. Taaffe and Leslie J. King, eds. Chicago: Rand McNally and Company.

1954. The Location of Agricultural Production. Gainesville: University of Florida Press.

Froberg, Sharon, September 17, 1974. Personal interview.

Harvey, David W., 1970. "Theoretical Concepts and the Analysis of Agricultural Land-Use Patterns in Geography," Economic Geography: Selected Readings, Dohrs, Fred E. and Lawrence M. Sommers, eds. New York: Thomas $Y$. Crowel1 company.

Helvig, Magne, 1964. Chicago's External Truck Movements: Spatial Interaction Between the Chicago Ārea and its Hinterland. Department of Geography Research Paper No. 90. Chicago: The University of Chicago.

Hurst, Michael E. Eliot, April, 1973. "Transportation and the Societal Framework," Economic Geography, 49:2, pp. 163-180.

Isard, Walter, 1956. Location and Space-Economy. New York: Technology Press of Massachusetts Institute of Technology and John Wiley and Sons, Inc.

1960. Methods of Regional Analysis: An Introduction to Regional Science. New York: Technology Press of Massachusetts Institute of Technology and John Wiley and Sons, Inc.

Kansky, K. J., 1963. Structure of Transportation Networks: Relationships Between Network Geometry and Regional Characteristics. Department of Geography Research 
Paper No. 84. Chicago: The University of Chicago.

Lösch, August, 1954. The Economics of Location, Translation by $\mathrm{W}$. H. Woglom. New Haven: Yale University Press. Original published by Gustav Fischer Verlag.

, 1970. "The Nature of Economic Regions," Economic Geography: Selected Readings, Dohrs, Fred $E$. and Lawrence M. Sommers, eds. New York: Thomas Y. Crowell Company.

Morgan, F. W., 1958. Ports and Harbors. Revised by James Bird. London: Hutchinson University Library.

Muller, Peter O., April, 1973. "Trend Surfaces of American Agricultural Patterns: A Macro-Thunian Analysis," Economic Geography, 49:3, pp. 228-242.

Oregon Department of Transportation, Ports Division, 1973. Survey of Oregon Ports: 1972. Salem, Oregon: Oregon Department of Transportation, Ports Division.

Patton, Donald J., December, 1958. "General Cargo Hinterlands of New York, Philadelphia, Baltimore, and New Orleans," Annals of the Association of American Geographers, 48 pp. $436-\overline{455}$.

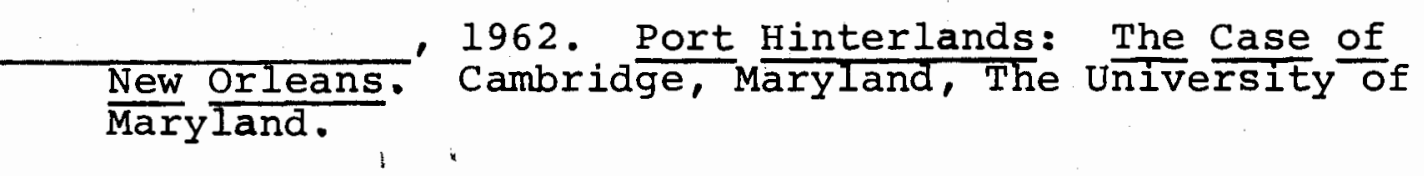

Port of Portland, 1974. 1973 Export and Import Domestic City Origin and Destination Report. Portland, Oregon: Port of Portland, (unpublished).

Pred, Allan, 1967. "Behavior and Location: Foundations for a Geographic and Dynamic Location Theory, Part 1," Lund Studies in Geography, Series B, Human Geography No. 27. The Royal University of Lund, Sweden, Department of Geography, C.W.K. Gleerup, Lund.

1 1969. "Behavior and Location: Foundations for a Geographic and Dynamic Location Theory, Part 2," Lund Studies in Geography, Series B, Human Geography, No. 28. The Royal University of Lund, Sweden, Department of Geography, C.W.K. Gleerup, Lund.

Rutherford, J., M. I. Logan and G. J. Missen, 1970. New Viewpoints in Economic Geography. Sydney: Martindale Press. 
Sargent, A. J., 1938. Seaports and Hinterlands. London: Adam and Charles Black.

Shaffer, N. Manfred, 1965. The Competitive Position of the Port of Durban. Studies in Geography, No. 8 . Evanston, Ilinois: Northwestern University Press.

Smith, R. H. T., 1974. "Concepts and Methods in Commodity Flow Analysis," Transportation Geography: Comments and Readings, Hurst, Michael E. Eliot, ed. New York: MCGraw-Hill Book Company.

Sun, Nai-Ching and Michael C. Bunamo, April, 1973. "Competition for Handling U.S. Foreign Trade Cargoes: The Port of New York's Experience," Economic Geography, 49:2, pp. 156-162.

Ullman, Edward L., 1957. American Commodity Flow: A Geographical Interpretation of Rail and Water Traffic Based on Principles of Spatial Interchange. seattle: University of Washington Press.

1943. Mobile: Industrial Seaport and Trade Center. Department of Geography. Chicago: University of Chicago Press.

, April, 1951. Rivers as Regional Bonds: The Columbia - Snake Example," The Geographical Review, 41 pp. 210-225.

1 1966. "The Role of Transportation and the Bases for Interaction," Man's Role in Changing the Face of the Earth, Thomas, Jr. Tilifim L,, ed. Chicago: The University of Chicago Press.

\section{, 1954. "Transportation Geography,"}

American Geography: Inventory and Prospect, James, Preston E. and Clarence F. Jones, eds. Syracuse, New York. Syracuse University Press.

Valavanis, Stefan, 1968. "Lösch on Location," Readings in Economic Geography: The Location of Economic Activity, Smith, Robert $\bar{H}$. T., Edward J. Taafe and Leslie J. King, eds. Chicago: Rand McNally and Company.

Van Cleef, Eugene, April, 1941. "Hinterlands and Umlands," The Geographical Review, 31, pp. 308-31l.

Weber, A., 1929. Theory of the Location of Industries. Chicago: University of Chicago Press (translation of 1909 German edition). 
Weigend, Guido G., 1967. "Some Elements in the Study of Port Geography," Readings in Economic Geography, Roepke, Howard G., ed. New York: John Wiley and Sons, Inc.

, January, 1956. "The Problem of Hinterland and Foreland as Illustrated by the Port of Hamburg," Economic Geography, 32, pp. 1-16.

Zipf, G. K., 1949. Human Behavior and the Principle of

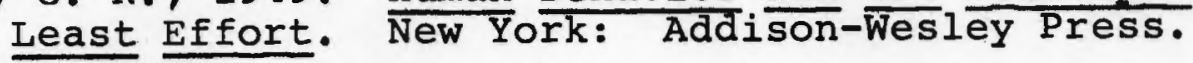




\begin{abstract}
APPENDIX A
COMMODITIES MOVING THROUGH THE PORT OF PORTLAND

BY FACILITY GROUPS 1973
\end{abstract}

$\begin{array}{ll}\text { Abbreviations: } & \text { NOS - Not otherwise specified } \\ & \text { NEC - Not elsewhere classified } \\ \text { CND - Canned } \\ \text { FR - Fresh } \\ \text { FZ - Frozen }\end{array}$

IMPORTS

$\underline{\text { Steel }}$

The following commodities were classified in the steel facility group because they are the major commodities that move through the Port of Portland's steel facility.

Iron Bars

Iron Sheets

Steel Flats and Bars

Steel Beams, Angles and Channels
Steel Coils

Steel Pipe and Tubing Steel Sheet and Plate Steel NEC

Automobiles

New Automobiles

Used Automobiles

Bulk, Containerized and Breakbulk

The following commodities can be shipped in either the containerized, breakbulk and, in some cases, bulk categories. Generally, ores and liquids move in bulk, but this is not always the case. All of the commodities listed below can 
be shipped in containers, but do not have to be. The

facility group classification used in the text is based on the method actually used to move the commodities, on an individual basis, in 1973.

Agates

Alcoholic beverages, NOS

Alcoholic beverages, beer

Alcoholic beverages, wine

Alcohol polyvinyl

Alumina

Aluminum chloride

Aluminum foil

Aluminum manufactures

Aluminum sheets

Ammonium bicarbonate

Ammonium chloride

Ammunition \& firearms

Anchovies, canned

Antimonyware

Apples, canned

Appliances

Arsenic powder

Artichokes, canned

Artificial flowers \& fruit

Asbestos articles

Ascorbic acid

Asparagus, CND

Auto parts

Axes

Bacon, canned

Bags, NOS

Ball bearings

Bamboo shoots

Bambooware

Basketware

Bauxite

Bearings, NOS

Beef casings

Beef, canned

Beef, frozen

Bicycles \& parts

Binoculars

Biscuits

Blood, dried

Boats \& parts

Bone meal

Books \& magazines
Brass sheets \& strips

Brassware

Brooms, corn

Brushes NOS

Bulbs, flower

Burlap

Burlap bags

Calcium chloride

Calculators

Cameras

Canoles

Carbon tetrachloride

Casein

Cast iron stoves

Caustic potash

Cement-white

Chains, Nos

Chains, link

Chains, roller

Cheese

Chemicals, NOS

Chestnuts

Chinaware

Christmas decorations

Christmas lights

Chrome

Chromium oxide

Cigarettes

Circular saw blades

Clams, canned

Clothing \& apparel

Cocoa crumbs

Cocoa powder

Coconut

Cod fillets

Coffee

Confectionery

Computer hardware

Cod liver oil, medicinal

Construction equipment, used

Conveyor belts

Cork, agglomerated

Cork board 
Corrugated sheets

Cotton cloth

Cotton goods

Cotton linters

Cotton waste

Crab, cNO

Creosote oil

Cryolite synthetic

Cube powder

Cylinders, empty

Dates

Decorative greens

Dextrine

Display material

Coors

Coorskins

Drugs \& medicine

Earthenware \& ceramicware

Eggs, hatching

Electric batteries

Electric bulbs

Electric motors

Electric products

Electric transformers

Electrodes, carbon

Electrodes, cathode

Electronic equipment \& instruments

Envelopes

Explosives

Expanded metal

Felt sheathing

Ferromanganese

Ferromanganese

Ferromanganese ore

Ferrous metal products

Fertilizer, NOS

Fiberboard

Fireworks

Fish, canned

Fish, frozen

Fish meal

Flatware

Flax scutched \& retted

Foodstuffs, NOS

Footware

Formic acid

Fruit, canned

Fruit, dried

Fruit, fresh

Fruit preserves

Furniture
Gas water heaters

Gelatine indust

Ginger beer

Glass mirrors

Glass plate \& window

Glass products

Glue

Granite blocks \& slabs

Hams, canned

Handbags \& purses

Handicrafts, NOS

Hardboard

Hardware \& tools

Herring, canned

Hides

Horseradish

Housewares

Ink, printing

Insulators, porcelain

Iron ore

Jute

Kapok

Kelp meal

Lacquerware

Lead

Lead concentrate

Leather manufactures

Limestone rock

Lingon berries

Linoleum

Locust bean gum-meal

Lobsters, frozen

Lumber, hardwood

Lumber, NOS

Lumber, softwood

Machinery \& parts

Machinery, agricultural

Machinery, diesel engines

Machinery, logging, lumber, plywood

Machinery, tractors

Magnesium chloride

Magnet powder

Marble manufactures

Marble slabs

Manganese metal

Manganese ore

Mats

Meat, canned

Medical-dental supplies

Metalware

Miscellaneous 
Molasses

Monochloreacetic acid Monosodium glutnate Motorcycles, parts, \& accessories

Mung beans

Mushrooms, canned

Musical instruments

Nails

Newspapers

Noodles

Nursery stock \& plants

Nuts, cashew

Nuts, brazil

Olives

Olive oil

onions, in brine

Onions, frozen

Optical goods

oranges, canned

Oranges, fresh

Ore, NOS

Oysters, canned

Paint

Paintings \& pictures

Palmyra stalks

Paper \& manufactures

Papayas

Paprika

Peatmoss

Perchlorethylene

Perfume

Pesticides

Pet food \& supplies

Petroleum products

Phonographs \& parts

Phosphate

Photographic materials

Pimentos

Pineapple, canned

Pineapple, fresh

Pipe \& pipe fittings

Pipe, galvanized

Plastic bags

Plastic manufactures

Plastic sheets

Plumbing supplies

Plywood \& veneer

Potassium permanganate

Printed matter, NOS

Quebracho extract

Radios
Rags wiping

Rainwear

Rattanware

Rope

Rubber, crude

Rubber manufactures

Rugs

Rye crisp

Salmon, canned

salt

Samples

Sardines, canned

Sausages

Saws, chain

Sea shells

Seed, NOS

Seedlac

Sewing machines \& parts

Shellac

Shrimp, canned

Shrimp, frozen

slate slabs

Snowmobiles

Sodium cyanide

Sodium trisulphate

Solder

Soy sauce

Spices

sporting goods

Squidbait, frozen

stainless steel sheets \& plates

stationery

Starch

Steel chains, Nos

Steel nuts, bolts, \& screws

Stereo equipment

Sugar

Syrup

Talc

Tamaride powder

Tape

Tape recorders

Tapioca flour

Tapioca pearls

Tar

Tea

Television sets

Tile

Tinplate

Tin slabs

Titanium ingots 
Titanium sponge (dioxide)

Tires \& tubes

Tomatoes, canned \& fresh

Toys

Travertine slabs

Tricaphos

Tropical fish

Trout, frozen

Tuna, canned

Tuna, frozen

Twine

Typewriters

Umbrellas

Urea

Valves \& gates

Vegetables, canned

Vegetables, frozen

Vermiculite
Vises machine

Wax

Wheat gluten

Wire

Wire baler

Wire cloth

wire fencing

Wire rope

Wood manufactures

Woodpulp

Wool

Yarn

Zinc ammonium chloride

zinc cincentrate

Zinc plates

Zirconium sponge (oxide)

Zircon sand \& flour

Zircon scrap

\section{EXPORTS}

Grain

Wheat

Barley

Liguid Bulk

Tallow

Tall Oil

Molasses

Logs

\section{Logs}

Dry Bulk, Containerized and Breakbulk

The following commodities can be shipped in either the containerized, breakbulk and, in some cases, dry bulk categories. Generally, ores and flowers move in bulk, but this is not a rule. All of the commodities listed below can be shipped in containers, but do not have to be. The facility group classification used in the text is based on 
the method actually used to move the commodities, on an individual basis, in 1973.

Abrasives

Adding \& accounting machinery Alcoholic beverages

Alfalfa cubes

Alfalfa pulp pellets

Aluminum ingots

Aluminum scrap

Ammunition \& firearms

Apple concentrate

Apples, dried

Apples, fresh

Appliances, major home

Asparagus

Asphalt

Avacados

Beans, canned

Beans, dried

Beans, fresh

Beans, frozen

Beet pulp pellets

Beets, canned

Bentonite clay

Berries, canned

Berries, fresh

Berries, frozen

Blackberries, fresh

Blackberries, frozen

Blueberries, fresh

Blueberries, frozen

Blood meal

Boats \& parts

Bone meal

Bowling equipment \& supplies

Boysenberries, canned

Boysenberries, fresh

Boysenberries, frozen

Brass scrap

Broccoli

Building supplies

Bulk, NOS

Burlap bags

Cabbage

Cants

Carrots, canned \& frozen

Carrots, fresh

Cascara bark

Cast iron pipe
Cauliflower

Chemicals, Nos

Cherries

Clothing

Coal

Coal tar pitch

Coke

Compressors

Copper cathodes

Copper bars \& Ingots

Copper scrap

Corn, canned

Corn, fresh

Corn, frozen

Corn, grain

Crab, FR

Crab, FZ

Display material

Doors

Doorskins

Electrical goods, NOS

Electrical motors

Essential oils, NOS

Fabric goods

Feather meal

Feed, poultry \& stock

Ferro phosphorous

Fertilizers

Fiberboard

Fiberglass \& products

Film

Fish, canned

Fish digest

Fish, fresh

Flour

Foodstuffs, canned

Foodstuffs, frozen

Foodstuffs, NOS

Fruit, canned

Fruit, concentrate Nos

Fruit juices, frozen

Furs

Gauges

Gilsonite

Glue

Grapes

Grass screening cubes 
Gypsum

Hand tools

Hardware

Hay cubes

Hides

Holly, fresh

Hop extract

Hops

Housewares

Hydrogen peroxide

Infusorial earth

Iron \& steel

Lead scrap

Lentils

Lettuce

Lift trucks \& parts

Lignin pitch

Linerboard

Livestock

Loganberries, fresh

Loganberries, frozen

Lubricating oil

Luggage

Lumber, hardwood

Lumber, NOS

Lumber products, NOS

Lumber, softwood

Machinery, agricultural

Machinery, heavy NEC

Machinery, light. NEC

Machinery, log, lumber, plywood

Machinery, mining

Machinery, NOS

Magazines

Magnesium cloride

Malt

Meat, canned

Meat, frozen

Meat meal

Medical-dental supplies

Metal castings

Metal ingots

Metal scrap

Metals, NOS

Microfilm equipment

Milk, canned

Milk, powdered

Millfeed pellets

Milo

Miscellaneous

Motorcycles \& parts
Nickel ingots

Nursery stock

Nuts

Oats

Oats, rolled

old newspaper \& scrap

Onions

Ore, NOS

Oscilliscopes \& parts

Oysters

Paints \& resins

Paper, NOS

Paper products

Particle board

Peaches

Pears, canned

Pears, fresh

Pear concentrate

Peas, canned

Peas, dried

Peas, fresh

Peas, frozen

Peppermint oil

Periodicals

Petroleum products NOS

Photographic equipment

Pickles

Pipe \& pipe fittings

Plastic sheet \& manufactures

Plums

Plywood

Poles

Potatoes, dehydrated

Potatoes, fresh

Potatoes, frozen

Potato flour

Potash

Poultry

Precut homes

Preserves

Prunes, dried

Pulpboard

Pumps

Rasberries, fresh

Rasberries, frozen

Rubber, crude

Rye

Salmon, frozen

Samples

Saw chains \& tools

Scoups \& parts

Seed, alfalfa 
Seed, bean

Seed, bentgrass

Seed, bluegrass

seed, clover

Seed, corn

Seed, fescue

seed, garden

Seed, grass

Seed, pea

Seed, ryegrass

Seed, timothy

seed, vegetable

Seed, orchardgrass

Shrimp, fresh

Shrimp, frozen

Soap \& powder

Soybeans

Spearmint oil

sporting goods

steel \& iron scrap

Strawberries, fresh

Strawberries, frozen

Talc

Technical instruments
Tinplate

Tin scrap

Tires \& tubes

Trailers \& parts

Trucks \& parts

Vegetables, canned

Vegetables, fresh

Vegetables, frozen

Vitamins, pills \& liquid

Wallboard

Weed killer compound

Whey

Wheat, rolled

Winches

Wire NOS

Wood burls

Woodchips

Woodfiller

Wood manufactures

Woodpulp

Youngberries, fresh

Youngberries, frozen

Zine

Zirconium sponge 
APPENDIX B

CITY ORIGINS OF EXPORTS FROM

PORT OF PORTLAND FACILITIES 1973

Abbreviations: NOS - Not otherwise specified

NEC - Not elsewhere classified

IIQUID BULK

\begin{tabular}{|c|c|c|c|}
\hline & Short Tons & $\underline{q}$ & $\begin{array}{l}8 \text { of Respective } \\
\text { State Total } \\
\end{array}$ \\
\hline $\begin{array}{l}\text { Billings, Montana } \\
\text { Columbia City, Oregon } \\
\text { Eugene, Oregon } \\
\text { Great Falls, Montana } \\
\text { Hillsboro, Oregon } \\
\text { Ontario, Oregon } \\
\text { Pasco, Washington } \\
\text { Portland, Oregon } \\
\text { Spokane, Washington } \\
\text { Yakima, Washington } \\
\text { Unknown }\end{array}$ & $\begin{array}{r}114.65 \\
25.36 \\
149.31 \\
59.74 \\
53.04 \\
147.10 \\
1,526.06 \\
19,939.07 \\
44.76 \\
72.68 \\
1,131.08\end{array}$ & $\begin{array}{r}0.49 \\
0.11 \\
0.64 \\
0.26 \\
0.23 \\
0.63 \\
6.56 \\
85.71 \\
0.19 \\
0.31 \\
4.86\end{array}$ & $\begin{array}{r}65.74 \\
0.12 \\
0.74 \\
34.26 \\
0.26 \\
0.72 \\
92.86 \\
98.16 \\
2.72 \\
4.42 \\
-\end{array}$ \\
\hline Total & $23,262.85$ & 99.99 * & - \\
\hline
\end{tabular}

GRAIN

Short Tons $\quad$ \& $\quad \begin{aligned} & 8 \text { of Respective } \\ & \text { State Total }\end{aligned}$

Kalama, Washington

Portland, Oregon

Unknown

11.55

0.00

100.00

$1,644,967.07$

$21,651.84$

98.70

100.00

Total

$1,666,630.46 \quad 100.00$

* Total does not sum to 1008 due to rounding 
DRY BULK

Alder, Montana
Brooks, Oregon
Grey Bull, Wyoming
Lovell, Wyoming
Oregon, All Other
$\quad$ Cities
Pocatello, Idaho
Portland, Oregon
Veneta, Oregon

Washington, Eastern NOS

Total

$\begin{array}{rrr}\text { Short Tons } & \& & \begin{array}{c}\text { zof Respective } \\ \text { of } \\ \text { State Total }\end{array} \\ 14,838.05 & 8.39 & 100.00 \\ 300.19 & 0.17 & 0.34 \\ 9,074.00 & 5.13 & 18.05 \\ 41,206.33 & 23.30 & 81.95 \\ 15,459.13 & 8.74 & 17.20 \\ 16,844.26 & 9.52 & 100.00 \\ 69,170.34 & 39.11 & 76.95 \\ 4,954.94 & 2.80 & 5.51 \\ 5,013.16 & 2.83 & 100.00 \\ 176,860.40 & 99.99 * & -\end{array}$

CONTAINERIZED
Alabama NOS

Albany, Oregon

Allendale, Idaho

Amity, Oregon

Anacortes, Washington

Astoria, Oregon

Athena, Oregon

Aumsville, Oregon

Aurora, Oregon

Baker, Idaho

Beaverton, Oregon

Battle Ground, Washington.

Belmont, Washington

Bend, Oregon

Billings, Montana

Billington, Washington

Bingen, Washington

Boise, Idaho

Bonner's Ferry, Idaho

Brooks, Oregon

Brownsville, Oregon

Buhl, Idaho

Caldwell, Idaho

Camas, Washington

Canby, Oregon

Carver, Oregon
Short Tons 8

4,

2.45

, 364.12

171.86

16.80

172.65

107.10

0.27

11.08

840.51

20.11

568.12

18.35

22.00

30.98

48.07

18.98

75.50

219.95

49.25

$14,368.92$

655.50

223.00

164.05

$2,254.82$

8.52

173.77
\& of Respective State Total

$$
100.00
$$

2.17

1.92

0.01

0.33

0.05

0.00

0.01

0.42

0.22

0.28

0.04

0.04

0.01

8.47

0.04

0.14

2.45

0.55

7.16

0.33

2.49

1.83

4.33

0.00

0.09

* Total does not sum to 1008 due to rounding 
Containerized (continued)

Cedar Rapids, Iowa

Centralia, Washington

Charleston, Oregon

Chehalis, Washington

Clackamas, Oregon

Columbia City, Oregon

Colfax, Washington

Colton, Oregon

Connell, Washington

Coos Bay, Oregon

Corvallis, Oregon

Cottage Grove, Oregon

Craigmont, Idaho

Culp Creek, Oregon

Dallas, Oregon

Dayton, Washington

Dillard, Oregon

Dishman, Washington

Donald, Oregon

Dundee, Oregon

Estacada, Oregon

Eugene, Oregon

Fairfield, Washington

Filer, Idaho

Forest Grove, Oregon

Foster, Oregon

Ft. Wayne, Indiana

Gardner, Oregon

Garfield, Washington

Garibaldi, Oregon

Gaston, Oregon

Glendale, Oregon

Gold Hill, Oregon

Gonzales, California

Gooding, Idaho

Grandview, Washington

Grandville, Idaho

Grants Pass, Oregon

Great Falls, Montana

Gresham, Oregon

Grey Bull, Wyoming

Halsey, Oregon

Hammond, Oregon

Harrah, Washington

Harrisburg, Oregon

Harrisburg, Washington

Hazelton, Idaho

Hermiston, Oregon
Short Tons

$\underline{8}$

$\&$ of Respective

State Total

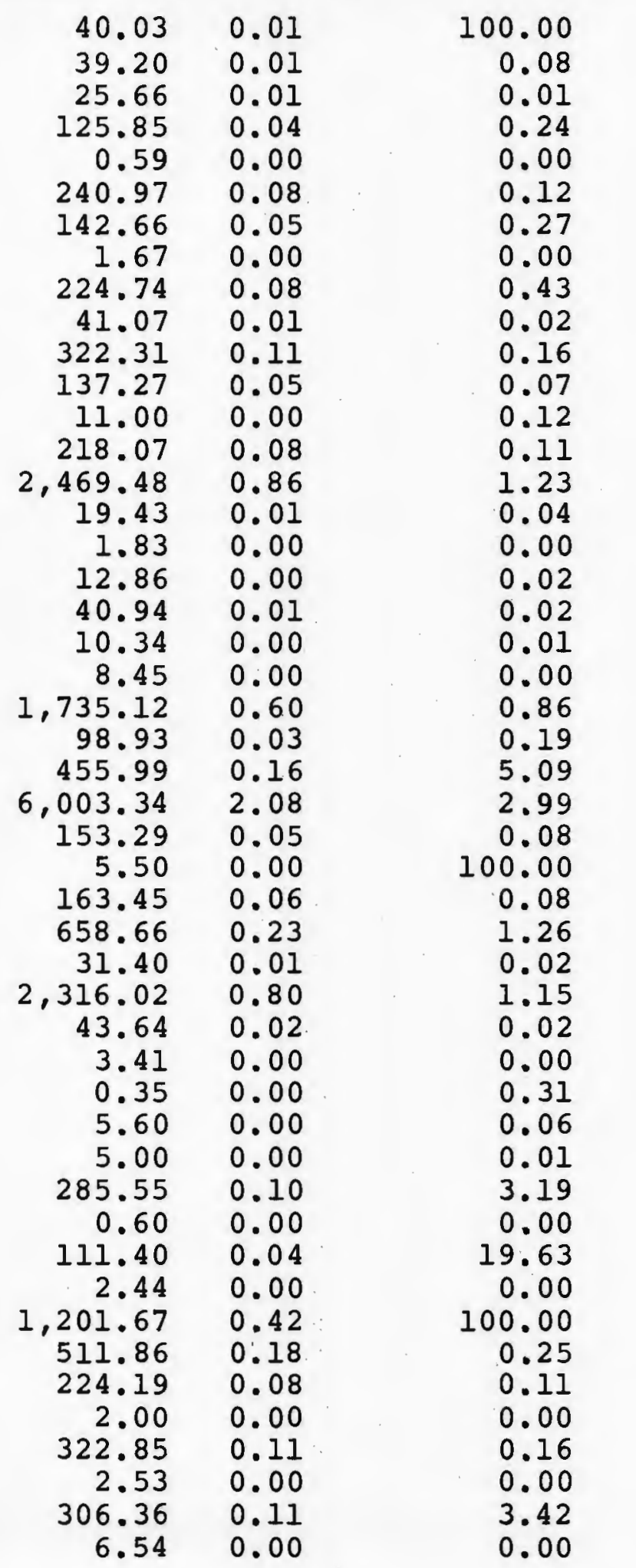


Containerized (continued)

\begin{tabular}{|c|c|c|c|}
\hline & Short Tons & 8 & $\begin{array}{l}\text { of Respective } \\
\text { State Total }\end{array}$ \\
\hline Hillsboro, Oregon & 328.10 & 0.11 & 0.16 \\
\hline Homedale, Idaho & 55.28 & 0.02 & 0.62 \\
\hline Hood River, Oregon & $1,265.96$ & 0.44 & 0.63 \\
\hline Hubbard, Oregon & 42.23 & 0.01 & 0.02 \\
\hline Idaho, Northeastern NOS & 307.15 & 0.11 & 3.43 \\
\hline Idaho Falls, Idaho & 108.38 & 0.04 & 1.21 \\
\hline Illinois NOS & 25.99 & 0.01 & 100.00 \\
\hline Independence, Oregon & 64.41 & 0.02 & 0.03 \\
\hline Ironton, Utah & 2.22 & 0.00 & 1.61 \\
\hline Jefferson, Oregon & $2,531.85$ & 0.88 & 1.26 \\
\hline Jerome, Idaho & 473.44 & 0.16 & 5.28 \\
\hline Kalama, Washington & 351.95 & 0.12 & 0.68 \\
\hline Kendrick, Idaho & 158.16 & 0.05 & 1.76 \\
\hline Kennewick, Washington & 199.49 & 0.07 & 0.38 \\
\hline Kimberly, Idaho & 818.38 & 0.28 & 9.13 \\
\hline Ketchikan, Arkansas & 43.82 & 0.02 & 8.98 \\
\hline Kirkland, washington & 0.38 & 0.00 & 0.00 \\
\hline La Grande, Oregon & 0.77 & 0.00 & 0.00 \\
\hline Lake Oswego, Oregon & 241.20 & 0.08 & 0.12 \\
\hline Lapwai, Idaho & 55.12 & 0.02 & 0.61 \\
\hline La Vern, Minnesota & 18.00 & 0.01 & 74.23 \\
\hline Lebanon, New Hampshire & 507.50 & 0.18 & 100.00 \\
\hline Lebanon, Oregon & 656.00 & 0.23 & 0.33 \\
\hline Lewiston, Idaho & 266.73 & 0.09 & 2.98 \\
\hline Linnton, Oregon & 191.23 & 0.07 & 0.10 \\
\hline Longview, Washington & $3,302.02$ & 1.15 & 6.33 \\
\hline Los Angeles, California & 5.50 & 0.00 & 4.89 \\
\hline Lowden, Washington & 21.06 & 0.01 & 0.04 \\
\hline Madras, Oregon & 272.75 & 0.09 & 0.14 \\
\hline Mapleton, Oregon & 117.25 & 0.04 & 0.06 \\
\hline Marsine, Idaho & 182.95 & 0.06 & 2.04 \\
\hline McMinnville, Oregon & 70.87 & 0.02 & 0.04 \\
\hline Medford, Oregon & 31.07 & 0.01 & 0.02 \\
\hline Metolius, Oregon & 23.92 & 0.01 & 0.01 \\
\hline Michigan, NOS & 3.77 & 0.00 & 100.00 \\
\hline Milner, Idaho & 5.60 & 0.00 & 0.06 \\
\hline Milton Freewater, Oregon & 515.13 & 0.18 & 0.26 \\
\hline Milwaukie, Oregon & 205.81 & 0.07 & 0.10 \\
\hline Minneapolis, Minnesota & 5.29 & 0.00 & 21.81 \\
\hline Minnesota NOS & 0.64 & 0.00 & 2.64 \\
\hline Missoula, Montana & 22.81 & 0.01 & 4.02 \\
\hline Molalla, Oregon & 313.14 & 0.11 & 0.16 \\
\hline Monmouth, Oregon & 60.29 & 0.02 & 0.03 \\
\hline Monroe, Oregon & 28.96 & 0.01 & 0.01 \\
\hline Moscow, Idaho & 855.08 & 0.30 & 9.54 \\
\hline Moses Lake, Washington & 10.00 & 0.00 & 0.02 \\
\hline Mountlake Terr, Washingto & 129.52 & 0.04 & 0.25 \\
\hline Moxee City, Washington & 1.95 & 0.00 & 0.00 \\
\hline
\end{tabular}




\begin{tabular}{|c|c|c|c|}
\hline & Short Tons & $\underline{8}$ & State Total \\
\hline Mount Angel, Oregon & 7.56 & 0.00 & 0.00 \\
\hline Myrtle Point, Oregon & 2.51 & 0.00 & 0.00 \\
\hline Nampa, Idaho & 647.17 & 0.22 & 7.22 \\
\hline Neal Creek, Oregon & 235.02 & 0.08 & 0.12 \\
\hline Nevada NOS & 68.81 & 0.02 & 100.00 \\
\hline Newberg, Oregon & 759.47 & 0.26 & 0.38 \\
\hline Newport, Oregon & 123.14 & 0.04 & 0.06 \\
\hline Newark, New Jersey & 20.86 & 0.01 & 100.00 \\
\hline Nezperce, Idaho & 45.09 & 0.02 & 0.50 \\
\hline North Bend, Oregon & 0.44 & 0.00 & 0.00 \\
\hline Nyssa, Oregon & 949.65 & 0.33 & 0.47 \\
\hline Notus, Idaho & 20.24 & 0.01 & 0.23 \\
\hline Oakland, California & 19.47 & 0.01 & 17.31 \\
\hline Oaksdale, Washington & 111.62 & 0.04 & 0.21 \\
\hline Ocean Park, Washington & 1.50 & 0.00 & 0.00 \\
\hline Odell, Oregon & 145.75 & 0.05 & 0.07 \\
\hline Ogden, Utah & 122.15 & 0.04 & 88.81 \\
\hline Ontario, Oregon & 514.84 & 0.18 & 0.26 \\
\hline Oregon, All Other Cities & 648.21 & 0.22 & 0.32 \\
\hline Othello, Washington & 193.28 & 0.07 & 0.37 \\
\hline Palouse, Washington & 103.60 & 0.04 & 0.20 \\
\hline Parma, Idaho & 286.02 & 0.10 & 3.19 \\
\hline Pasco, Washington & $2,101.07$ & 0.73 & 4.03 \\
\hline Payette, Idaho & 214.93 & 0.07 & 2.40 \\
\hline Pendleton, Oregon & 154.28 & 0.05 & 0.08 \\
\hline Pennsylvania NOS & 33.12 & 0.01 & 100.00 \\
\hline Phoenix, Arizona & 447.49 & 0.16 & 100.00 \\
\hline Pocatello, Idaho & 147.40 & 0.05 & 1.64 \\
\hline Pomeroy, Washington & 94.12 & 0.03 & 0.18 \\
\hline Port orford, Oregon & 110.55 & 0.04 & 0.06 \\
\hline Portland, Oregon & $106,757.74$ & 37.05 & 53.16 \\
\hline Potlatch, Washington & 0.04 & 0.00 & 0.00 \\
\hline Powers, Oregon & 5.93 & 0.00 & 0.00 \\
\hline Progress, Oregon & 130.86 & 0.05 & 0.07 \\
\hline Pullman, Washington & 1.70 & 0.00 & 0.00 \\
\hline Quincy, Washington & 21.61 & 0.01 & 0.04 \\
\hline Rainier, Washington & 571.32 & 0.20 & 1.10 \\
\hline Randle, Washington & 44.09 & 0.02 & 0.08 \\
\hline Rathbrum, Idaho & 0.42 & 0.00 & 0.00 \\
\hline Redmond, Oregon & 47.59 & 0.02 & 0.02 \\
\hline Renton, Washington & 2.69 & 0.00 & 0.01 \\
\hline Rickreall, oregon & 94.76 & 0.03 & 0.05 \\
\hline Riddle, Oregon & $1,306.79$ & 0.45 & 0.65 \\
\hline Ridgefield, Washing & 97.54 & 0.03 & 0.19 \\
\hline Roseburg, Oregon & 333.40 & 0.12 & 0.17 \\
\hline Saginaw, Oregon & 467.43 & 0.16 & 0.23 \\
\hline Salem, Oregon & $2,568,79$ & 0.89 & 1.28 \\
\hline Salt Lake City, U & 13.17 & 0.00 & 9.58 \\
\hline
\end{tabular}


Containerized (continued)

\section{Short Tons}

8 of Respective State Total

San Francisco, California

Scappoose, Oregon

Seattle, Washington

Selah, Washington

Shaniko, Oregon

Shedd, Oregon

Shelly, Idaho

Sheridan, Oregon

Sherwood, Oregon

Silverton, Oregon

Spokane, Washington

Springfield, Oregon

st. Helens, Oregon

Stanfield, Oregon

Stayton, Oregon

St. John, Washington

St. Paul, Oregon

Stuttgart, Arkansas

Sublimity, Oregon

Sunal, Nebraska

Sunnyside, Washington

Summer, Washington

Sweet Home, Oregon

Tacoma, Washington

Tangent, Oregon

Tennessee NOS

Texas Nos

The Dalles, Oregon

Three Forks, Montana

Tigard, Oregon

Tillamook, Oregon

Tilma, Washington

Toppenish, Washington

Touchet, Washington

Trentwood, Washington

Troutdale, Oregon

Troy, Idaho

Tualatin, Oregon

Twin Falls, Idaho

Underwood, washington

Vancouver, Washington

Virginia NoS

Walla Walla, Washington

Wapato, Washington

Warrenton, Oregon

\begin{tabular}{|c|c|c|}
\hline $\begin{array}{r}87.13 \\
3.00 \\
560.23 \\
43.03 \\
1,060.00 \\
526.09 \\
37.00 \\
22.17 \\
1,130.40 \\
127.80 \\
1,703.64 \\
20,343.24 \\
1,798.54 \\
19.19 \\
205.47 \\
19.76 \\
5.50 \\
443.92 \\
5.50 \\
116.64 \\
31.36 \\
338.00 \\
822.58 \\
61.78 \\
1,790.45 \\
159.89 \\
175.47 \\
8,120.81 \\
385.22 \\
140.44 \\
4,899.07 \\
51.75 \\
924.86 \\
37.55 \\
43.77 \\
879.61 \\
417.03 \\
21.08 \\
1,932.28 \\
26.92 \\
35,836.85 \\
124.92 \\
428.24 \\
179.22 \\
132.78 \\
376.22\end{array}$ & $\begin{array}{l}0.03 \\
0.00 \\
0.19 \\
0.01 \\
0.37 \\
0.18 \\
0.01 \\
0.01 \\
0.39 \\
0.04 \\
0.59 \\
7.06 \\
0.62 \\
0.01 \\
0.07 \\
0.01 \\
0.00 \\
0.15 \\
0.00 \\
0.04 \\
0.01 \\
0.12 \\
0.29 \\
0.02 \\
0.62 \\
0.06 \\
0.06 \\
2.82 \\
0.13 \\
0.05 \\
1.70 \\
0.02 \\
0.32 \\
0.01 \\
0.02 \\
0.31 \\
0.14 \\
0.01 \\
0.67 \\
0.01 \\
12.44 \\
0.04 \\
0.15 \\
0.06 \\
0.05 \\
0.13\end{array}$ & $\begin{array}{r}77.48 \\
0.00 \\
1.07 \\
0.08 \\
0.53 \\
0.26 \\
0.41 \\
0.01 \\
0.56 \\
0.06 \\
3.27 \\
10.13 \\
0.90 \\
0.01 \\
0.10 \\
0.04 \\
0.00 \\
91.02 \\
0.00 \\
100.00 \\
0.06 \\
0.65 \\
0.41 \\
0.12 \\
0.89 \\
100.00 \\
100.00 \\
4.04 \\
67.88 \\
0.07 \\
2.44 \\
0.10 \\
1.77 \\
0.07 \\
0.08 \\
0.44 \\
4.65 \\
0.01 \\
21.55 \\
0.05 \\
68.74 \\
100.00 \\
0.82 \\
0.34 \\
0.07 \\
0.72\end{array}$ \\
\hline
\end{tabular}


Containerized (continued)

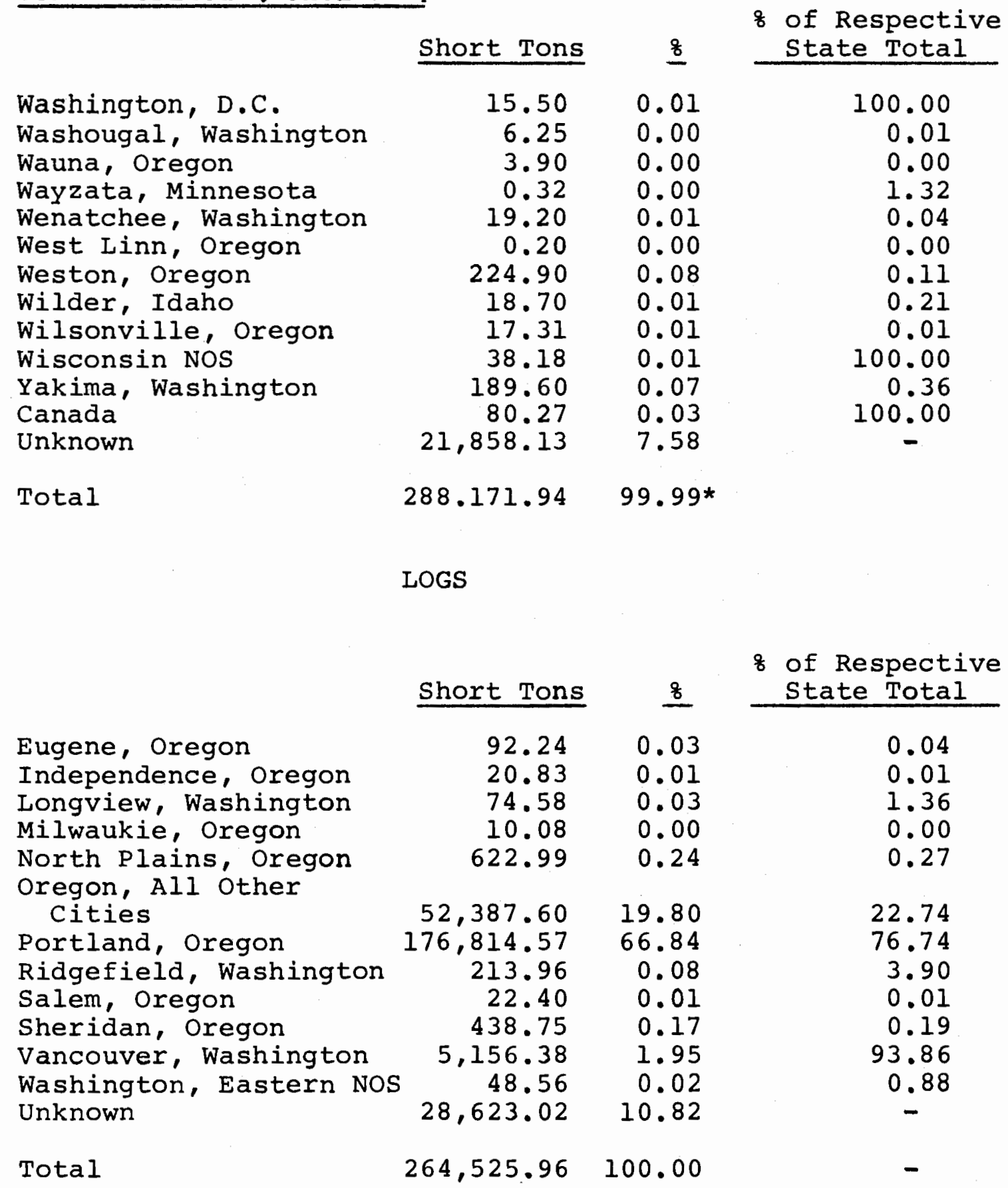

* Total does not sum to 1008 due to rounding. 
BREAKBULK

\begin{tabular}{|c|c|c|c|}
\hline & Short Tons & 8 & State Total \\
\hline Albany, Oregon & $8,285.13$ & 2.19 & 2.82 \\
\hline Amboy, washington & $1,254.87$ & 0.33 & 2.18 \\
\hline Amity, Oregon & 5.50 & 0.00 & 0.00 \\
\hline Anacortes, Washington & $1,179.99$ & 0.31 & 2.05 \\
\hline Arcata, California & 2.97 & 0.00 & 0.34 \\
\hline Ashland, Oregon & 40.07 & 0.01 & 0.01 \\
\hline Arkansas NOS & 46.21 & 0.01 & 100.00 \\
\hline Astoria, Oregon & $1,730.25$ & 0.46 & 0.59 \\
\hline Athena, oregon. & 7.40 & 0.00 & 0.00 \\
\hline Baker, Idaho & 2.15 & 0.00 & 0.03 \\
\hline Banks, Oregon & 24.45 & 0.01 & 0.01 \\
\hline Beaverton, Oregon & $1,173.75$ & 0.31 & 0.40 \\
\hline Battle Ground, Washingtor & $n \quad 28.33$ & 0.01 & 0.05 \\
\hline Belle Fourche, & & & \\
\hline South Dakota & 185.50 & 0.05 & 100.00 \\
\hline Belmont, washington & 183.70 & 0.05 & 0.32 \\
\hline Bend, Oregon & 176.15 & 0.05 & 0.06 \\
\hline Bingen, Washington & 494.77 & 0.13 & 0.86 \\
\hline Black Eagle, Montana & 0.23 & 0.00 & 0.01 . \\
\hline Blackfoot, Idaho & 2.24 & 0.00 & 0.03 \\
\hline Blue Lake, California & 70.90 & 0.02 & 8.17 \\
\hline Boise, Idaho & 129.65 & 0.03 & 1.55 \\
\hline Boones Ferry, Idaho & 94.05 & 0.02 & 1.13 \\
\hline Boring, Oregon & 404.80 & 0.11 & 0.14 \\
\hline Bremerton, Washington & 35.94 & 0.01 & 0.06 \\
\hline Brookings, Oregon & 816.67 & 0.22 & 0.28 \\
\hline Brooks, Oregon & 73.16 & 0.02 & 0.02 \\
\hline Buhl, Idaho & 231.76 & 0.06 & 2.78 \\
\hline Caldwell, Idaho & 28.46 & 0.01 & 0.34 \\
\hline California NOS & 287.36 & 0.08 & 33.10 \\
\hline Camas, Washington & $10,699.31$ & 2.82 & 18.57 \\
\hline Canby, Oregon & 20.70 & 0.01 & 0.01 \\
\hline Carlton, oregon & 0.84 & 0.00 & 0.00 \\
\hline Carver, oregon & $4,356.23$ & 1.15 & 1.49 \\
\hline Cascadia, Oregon & 21.45 & 0.01 & 0.01 \\
\hline Charleston, Oregon & 4.04 & 0.00 & 0.00 \\
\hline Chehalis, Washington & 398.08 & 0.11 & 0.69 \\
\hline Cherry Hills, New Jersey & 10.31 & 0.00 & 100.00 \\
\hline Chelan, Washington & 41.40 & 0.01 & 0.07 \\
\hline Chelatchie, Washington & 996.48 & 26 & 1.73 \\
\hline Chicago, Illinois & 21.10 & 0.01 & 15.02 \\
\hline Clackamas, Oregon & 880.50 & 0.23 & 0.30 \\
\hline cody, wyoming & $5,956.04$ & 1.57 & 92.18 \\
\hline Colfax, Washington & 110.11 & 0.03 & 0.19 \\
\hline Concord, Maine & 0.02 & 0.00 & 100.00 \\
\hline
\end{tabular}


Breakbulk (continued)

Conne11, Washington Coos Bay, Oregon Coquille, Oregon Cosmopolis, Washington Corvallis, Oregon Cottage Grove, Oregon Craigmont, Idaho Cowiche, Washington Culp Creek, Oregon Dallas, Oregon Dallas, Texas Danville, Illinois Dayton, Washington Dexter, Oregon Dillard, Oregon Dishman, Washington Donald, Oregon Dundee, Oregon Dunham, Montana Emmett, Idaho Empire, Oregon Estacada, Oregon Eugene, Oregon Filer, Idaho Forest Grove, Oregon Foster, Oregon Fresno, California Gardner, Oregon Garfield, Washington Garibaldi, Oregon Gaston, Oregon Gervais, Oregon Gladstone, Oregon Glendale, oregon Gold Beach, Oregon Gold Hill, Oregon Goldendale, Washington Goshen, Oregon Grand Ronde, Oregon Grandview, Washington Grandville, Idaho Grants Pass, Oregon Great Falls, Montana Gresham, Oregon Griggs, Oregon Halsey, Oregon Hammond, Oregon
Short Tons

8 of Respective State Total

\begin{tabular}{|c|c|c|}
\hline $\begin{array}{r}5.36 \\
728.66 \\
59.10 \\
207.79 \\
8,583.94 \\
225.71 \\
444.64 \\
40.09 \\
1,343.89 \\
11,698.53 \\
114.98 \\
1.94 \\
7.00 \\
1,808.47 \\
310.00 \\
7.23 \\
10.33 \\
41.19 \\
40.00 \\
18.40 \\
111.49 \\
4,603.72 \\
14,734.98 \\
606.76 \\
904.68 \\
3,306.47 \\
22.02 \\
1,512.56 \\
3,919.42 \\
240.64 \\
47.74 \\
6.84 \\
11.44 \\
61.13 \\
496.69 \\
1.01 \\
65.87 \\
495.00 \\
1,649.27 \\
21.81 \\
86.82 \\
856.41 \\
243.82 \\
57.09 \\
2,695.79 \\
831.14 \\
54.92\end{array}$ & $\begin{array}{l}0.00 \\
0.19 \\
0.02 \\
0.05 \\
2.27 \\
0.06 \\
0.02 \\
0.01 \\
0.35 \\
3.09 \\
0.03 \\
0.00 \\
0.00 \\
0.48 \\
0.08 \\
0.00 \\
0.00 \\
0.01 \\
0.01 \\
0.00 \\
0.03 \\
1.21 \\
3.89 \\
0.16 \\
0.24 \\
0.87 \\
0.01 \\
0.40 \\
1.03 \\
0.06 \\
0.01 \\
0.00 \\
0.00 \\
0.02 \\
0.13 \\
0.00 \\
0.02 \\
0.13 \\
0.44 \\
0.01 \\
0.02 \\
0.23 \\
0.06 \\
0.02 \\
0.71 \\
0.22 \\
0.01\end{array}$ & $\begin{array}{l}0.01 \\
0.25 \\
0.02 \\
0.36 \\
2.93 \\
0.08 \\
5.33 \\
0.07 \\
0.46 \\
3.99 \\
89.37 \\
1.38 \\
0.01 \\
0.62 \\
0.11 \\
0.01 \\
0.00 \\
0.01 \\
2.34 \\
0.22 \\
0.04 \\
1.57 \\
5.02 \\
7.27 \\
0.31 \\
1.13 \\
2.54 \\
0.52 \\
6.80 \\
0.08 \\
0.02 \\
0.00 \\
0.00 \\
0.02 \\
0.17 \\
0.00 \\
0.11 \\
0.17 \\
0.56 \\
0.04 \\
1.04 \\
0.29 \\
14.29 \\
0.02 \\
0.92 \\
0.28 \\
0.02 \\
0.01\end{array}$ \\
\hline
\end{tabular}


Breakbulk (continued)

\begin{tabular}{|c|c|c|c|}
\hline & Short Tons & 8 & $\begin{array}{l}\text { of Respective } \\
\text { State Total }\end{array}$ \\
\hline Harrah, Washington & 2.70 & 0.00 & 0.00 \\
\hline Harrisburg, Oregon & 159.06 & 0.04 & 0.05 \\
\hline Harrisburg, Washington & 10.01 & 0.00 & 0.02 \\
\hline HazeIton, Idaho & 366.91 & 0.10 & 4.39 \\
\hline Helena, Montana & 2.53 & 0.00 & 0.15 \\
\hline Hillsboro, Oregon & 109.81 & 0.03 & 0.04 \\
\hline Hood River, Oregon & $5,995.69$ & 1.58 & 2.04 \\
\hline Hoquiam, Washington & $1,385.01$ & 0.37 & 2.40 \\
\hline Houma, Louisiana & 1.50 & 0.00 & 100.00 \\
\hline Hubbara, Oregon & 21.55 & 0.01 & 0.01 \\
\hline Idaho, Northeastern NOS & 19.32 & $0.0 I$ & 0.23 \\
\hline Idaho Falls, Idaho & 24.80 & 0.01 & 0.30 \\
\hline Illinois NOS & 31.89 & 0.01 & 22.70 \\
\hline Imbler, Oregon & 20.20 & 0.01 & 0.01 \\
\hline Iowa NOS & 20.98 & 0.01 & 100.00 \\
\hline Ironton, Utah & $I, 545.90$ & 0.41 & 52.75 \\
\hline Jasper, Oregon & 854.29 & 0.23 & 0.29 \\
\hline Jerome, Idaho & 109.42 & 0.03 & 1.31 \\
\hline Junction City, Oregon & $2,788.01$ & 0.74 & 0.95 \\
\hline Kalama, Washington & $1,554.04$ & 0.41 & 2.70 \\
\hline Kansas City, Missouri & 0.26 & 0.00 & 100.00 \\
\hline Kellogg, Idaho & 39.96 & 0.01 & 0.48 \\
\hline Kelso, Washington & 3.50 & 0.00 & 0.01 \\
\hline Kendrick, Idaho & 997.44 & 0.26 & 11.95 \\
\hline Kent, washington & 13.24 & 0.00 & 0.03 \\
\hline Kimberly, Idaho & 448.79 & 0.12 & 5.38 \\
\hline Ia Grande, Oregon & 6.78 & 0.00 & 0.00 \\
\hline Lake Oswego, Oregon & 520.88 & 0.14 & 0.18 \\
\hline Lapwai, Idaho & 100.75 & 0.03 & 1.21 \\
\hline Iras Vegas, Nevada & 203.38 & 0.05 & 91.77 \\
\hline Lebanon, New Hampshire & 161.98 & 0.04 & 100.00 \\
\hline Lebanon, Oregon & $10,663.00$ & 2.81 & 3.64 \\
\hline Lewiston, Idaho & 829.19 & 0.22 & 9.93 \\
\hline Libby, Montana & 406.89 & 0.11 & 23.85 \\
\hline Liberal, Oregon & 312.56 & 0.08 & 0.11 \\
\hline Iinnton, oregon & 191.46 & 0.05 & 0.07 \\
\hline Longview, Texas & 13.67 & 0.00 & 10.62 \\
\hline Longview, Washington & 602.44 & 0.95 & 6.25 \\
\hline Los Angeles, California & 1.59 & 0.00 & 0.18 \\
\hline Lowden, Washington & 47.77 & 0.01 & 0.08 \\
\hline Lyons, Oregon & 13.42 & 0.00 & 0.00 \\
\hline Madras, Oregon & 157.67 & 0.04 & 0.05 \\
\hline Malaga, Washington & 198.99 & 0.05 & 0.35 \\
\hline Maltby, Washington & 1.15 & 0.00 & 0.00 \\
\hline Mapleton, Oregon & 244.80 & 0.33 & 0.42 \\
\hline McMinnville, Oregon & $2,210.28$ & 0.58 & 0.75 \\
\hline Medford, Oregon & $3,297.00$ & 0.87 & 1.12 \\
\hline
\end{tabular}


Breakbulk (continued)

Short Tons

Metolius, Oregon

Merlin, Oregon

Michigan NOS

Mill City, Oregon

Milton Freewater, Oregon

Milwaukee, Wisconsin

Milwaukie, Oregon

Minneapolis, Minnespta

Mississippi, NOS

Molalla, Oregon

Monroe, Oregon

Moscow, Idaho

Moses Lake, Washington

Mountlake Terr, Washington

Mount Angel, Oregon

Mount Vernon, Washington

Myrtle Creek, Oregon

Myrtle Point, Oregon

Nampa, Idaho

Neal Creek, Oregon

Nevada NOS

Newberg, Oregon

Newport, Oregon

Nezperce, Idaho

North Bend, Oregon

North Plains, Oregon

Norwalk Connecticut

Nyssa, Oregon

Oak Grove, Oregon

Oakridge, Oregon

Oaksdale, Washington

Ocean Park, Washington

Odell, Oregon

Ohio NOS

Olympia, Washington

oregon, All Other Cities

oregon City, oregon

othello, washington

Packwood, Washington

Palouse, Washington

Parkdale, Oregon

Pasco, Washington

Payette, Idaho

Pedee, Oregon

Pendleton, Oregon

Pennsylvania NOS

Philomath, Oregon

29

310.48

912.22

22.48

25.41

4.76

1.22

7.92

79.26

215.53

164.70

18.24

252.93

14.80

68.52

116.35

647.67

1.32

29.75

73.49

112.50

117.67

0.40

404.57

2.25

914.99

$5,723.24$

$1,102.57$

57.31

695.46

395.57

19.20

16.16

149.11

59.65

$1,093.38$

198.93

23.10
$29,938.89$
\& of Respective

State Total

0.02

0.00

0.01

0.02

0.04

0.00

0.20

0.00

0.01

7.90

0.08

0.24

0.01

0.01

0.00

0.00

0.00

0.02

0.06

0.04

0.00

0.07

0.00

0.02

0.03

0.17

0.00

0.01

0.02

0.03

0.05

0.00

0.11

0.00

0.24

I. 51

0.29

0.02

0.18

0.10

0.01

0.00

0.04

0.02

0.29

0.05

0.01
0.03

0.00

100.00

0.02

0.05

65.11

0.26

100.00

100.00

10.21

0.11

10.93

0.04

0.04

0.00

0.00

0.00

0.03

2.58

0.06

8.23

0.09

0.01

0.82

0.04

0.22

100.00

0.01

0.03

0.04

0.31

0.00

0.14

100.00

1.59

1.95

0.38

0.10

1.21

0.69

0.01

0.03

1.79

0.02

0.37

100.00

0.01 
Breakbulk (continued)

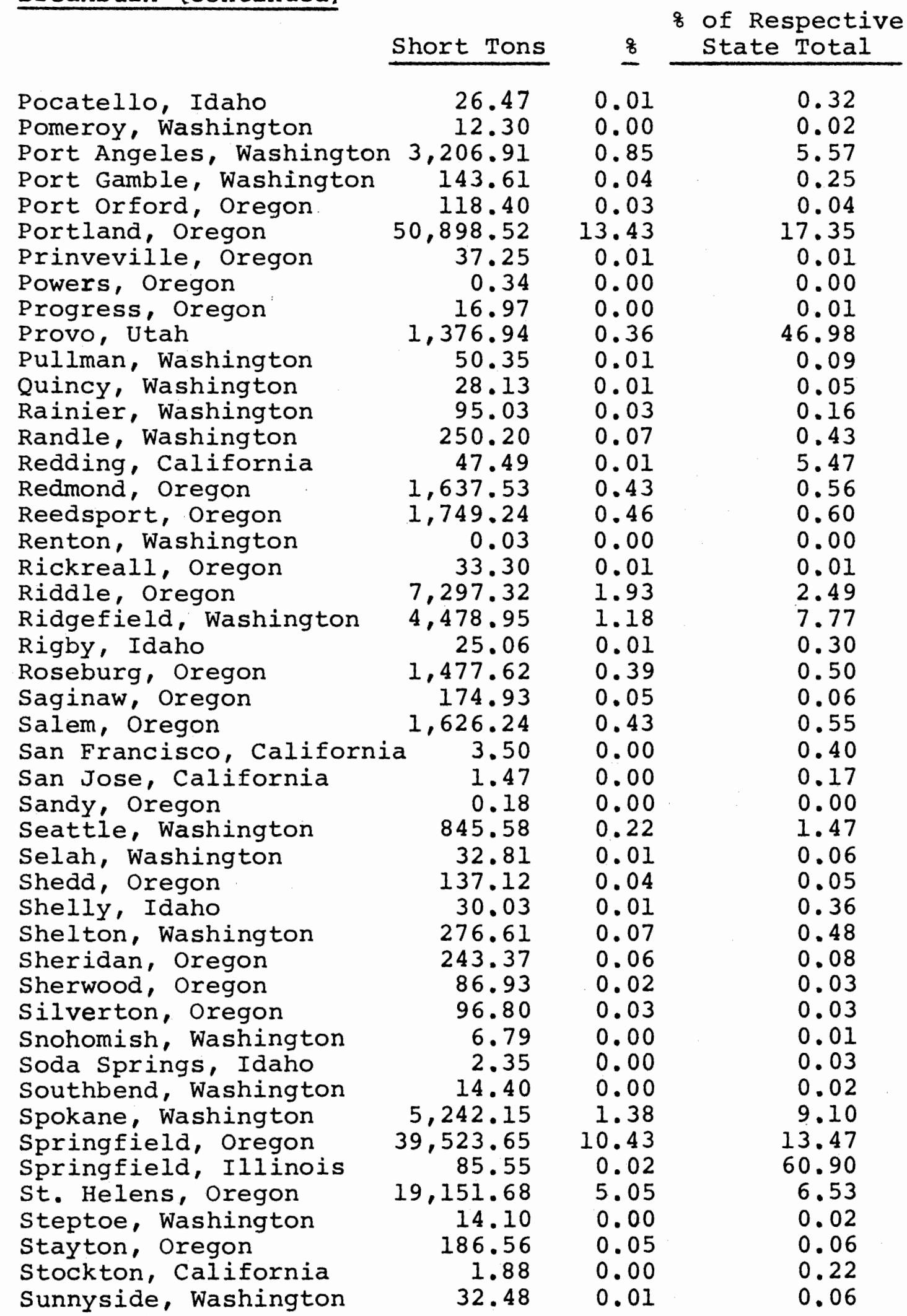


Breakbulk (continued)

Sweet Home, Oregon

Tacoma, Washington

Tangent, Oregon

Tekoa, Washington

The Dalles, Oregon

Three Forks, Montana

Tigard, Oregon

Tillamook, Oregon

Tilma, Washington

Toledo, Oregon

Toppenish, Washington

Trentwood, Washington

Troy, Idaho

Tualatin, Oregon

Tucson, Arizona

Twin Falls, Idaho

Underwood, Washington

Utah NOS

Vancouver, British

Columbia

Vancouver, Washington

Veneta, Oregon

Walla Walla, Washington

Wallula, Washington

Wapato, Washington

Warm Springs, Oregon

Warrenton, Oregon

Washington, Eastern NOS

Washougal, Washington

Wauna, Oregon

Weed, California

West Linn, Oregon

Wheeler, Oregon

Willamina, Oregon

Wilsonville, Oregon

Winlock, Washington

Wisconsin NOS

Woodburn, Oregon

Woodland, Washington

Wyoming NOS

Yakima, Washington

Zillah, Washington

Canada, Except Vancouver

B.C.

Unknown

Total

$378,935.00 \quad 99.99 *$
8 of Respective

Short Tons

$7,217.83$

$1,560.43$

861.02

220.50

$5,231.72$

$1,012.34$

$2,120.50$

$1,411.87$

356.38

$1,842.65$

$1,062.62$

32.00

$1,305.15$

329.20

3.93

$1,033.50$

395.60

7.85

123.17

$7,957.22$

$1,028.56$

16.52

28.08

121.06

355.24

190.73

$1,010.04$

798.48

$1,006.16$

429.08

$1,786.11$

4.88

83.55

2.22

28.12

1.64

25.26

1.06

505.00

465.86

2.30

0.03

2.10

0.27

0.00

0.01

0.03

0.09

0.05

0.27

0.21

0.27

0.11

0.47

0.00

0.02

0.00

0.01

0.00

0.01

0.00

0.13

0.12

0.00

100.00

13.81

0.35

0.03

0.05

0.21

0.12

0.07

1.75

1. 39

0.34

49.42

0.61

0.00

0.03

0.00

0.05

34.89

0.01

0.00

7.82

0.81

0.00

10.82
$6,331.85$

0.00

1.67

100.00

* Total does not sum to 1008 due to rounding. 


\begin{abstract}
APPENDIX C
CITY DESTINATIONS OF IMPORTS THROUGH

PORT OF PORTLAND FACILITIES 1973
\end{abstract}

Abbreviations: NOS - Not otherwise specified

NEC - Not elsewhere classified

BULK

Short Tons

Portland, Oregon

Tacoma, Washington

$194,560.20$

815.70
0.56
477.05

Vancouver, Washington

Unknown

Total
99.34
0.42
0.00
0.24

8 of Respective

8 State Total

$195,853.51 \quad 100.00$
100.00
99.93
0.07
$-$

CONTAINERIZED

\section{Short Tons}

Albany, Oregon

Aloha, Oregon

Ashland, Oregon

Astoria, Oregon

Athena, Oregon

Atlantic City, New Jersey

Aurora, Oregon

Beaverton, Oregon

Bend, Oregon

Billings, Montana

Boise, Idaho

Bozeman, Montana

Brooks, Oregon

Caldwell, Idaho

California NOS

Camas, Washington $z$ of Respective

\& State Total

0.28

0.01

0.00

3.13

0.01

0.01

0.01

1.92

0.00

0.06

0.39

0.00

0.06

0.02

0.00

0.38
0.38

0.01

0.00

4.21

0.01

7.67

0.01

2.59

0.00

48.43

80.46

0.13

0.09

3.69

2.28

2. 30 
Containerized (continued)

\section{Short Tons}

Canby, Oregon

Cariton, oregon

Cascadia, Oregon

Charleston, Oregon

Chicago, Illinois

Clackamas, Oregon

Cleveland, Ohio

Coos Bay, Oregon

Corvaliis, Oregon

Dallas, Oregon

Dallas, Texas

Downey, California

Du Bois, Pennsylvania

Dundee, Oregon

Eugene, Oregon

Forest Grove, Oregon

Franklin Park, Illinois

Gardena, California

Gladstone, Oregon

Goldendale, Washington

Grants Pass, Oregon

Grey Bull, Wyoming

Halsey, Oregon

Harrisburg, Oregon

Helena, Montana

Hilisboro, Oregon

Hood River, Oregon

Idaho, Northeastern NOS

Illinois NOS

Joseph, Oregon

Junction City, oregon

King Salmon, Alaska

La Grande, Oregon

Lake oswego, Oregon

Lincolnwood, Illinois

Longview, Texas

Longview, Washington

Los Angeles, California

McMinnville, Oregon

Medford, Oregon

Michigan NOS

Milwaukee, Wisconsin

Milwaukie, Oregon

Minneapolis, Minnesota

Nampa, Idaho

New York, New York

New Jersey NOS

Newberg, Oregon
$\%$ of Respective 8 State Total

$\begin{array}{rrr}68.78 & 0.11 & 0.15 \\ 0.90 & 0.00 & 0.00 \\ 0.50 & 0.00 & 0.00 \\ 21.30 & 0.04 & 0.05 \\ 420.10 & 0.69 & 13.81 \\ 58.06 & 0.10 & 0.13 \\ 78.42 & 0.13 & 99.28 \\ 11.37 & 0.02 & 0.03 \\ 89.29 & 0.15 & 0.20 \\ 17.58 & 0.03 & 0.04 \\ 204.97 & 0.34 & 75.12 \\ 1.96 & 0.00 & 1.58 \\ 0.11 & 0.00 & 3.24 \\ 4.11 & 0.01 & 0.01 \\ 717.93 & 1.18 & 1.59 \\ 76.88 & 0.13 & 0.17 \\ 174.22 & 0.29 & 5.73 \\ 1.20 & 0.00 & 0.97 \\ 2.15 & 0.00 & 0.00 \\ 982.60 & 1.62 & 9.85 \\ 433.39 & 0.71 & 0.96 \\ 12.41 & 0.02 & 100.00 \\ 10.51 & 0.02 & 0.02 \\ 13.78 & 0.02 & 0.03 \\ 41.05 & 0.07 & 51.44 \\ 609.98 & 1.01 & 1.35 \\ 34.80 & 0.06 & 0.08 \\ 0.22 & 0.00 & 0.08 \\ 241.66 & 0.40 & 7.94 \\ 0.06 & 0.00 & 0.00 \\ 0.17 & 0.00 & 0.00 \\ 43.56 & 0.07 & 100.00 \\ 17.42 & 0.03 & 0.04 \\ 5.26 & 0.01 & 0.01 \\ 320.81 & 0.53 & 10.54 \\ 63.36 & 0.10 & 23.22 \\ 622.71 & 9.27 & 56.35 \\ 5.71 & 0.01 & 4.59 \\ 217.97 & 0.36 & 0.48 \\ 52.73 & 0.09 & 0.12 \\ 222.32 & 0.37 & 100.00 \\ 63.63 & 0.10 & 99.64 \\ 734.87 & 1.21 & 1.63 \\ 14.43 & 0.02 & 100.00 \\ 3.74 & 0.01 & 1.29 \\ 147.14 & 0.24 & 59.93 \\ 33.48 & 0.06 & 55.49 \\ 57.18 & 0.09 & 0.13\end{array}$


Containerized (continued)

\section{Short Tons}

\section{8}

8 of Respective State Total

Newport, Oregon

New York NOS

North Bend, Oregon

Nyssa, Oregon

Oregon, All other Cities

Oregon City, Oregon

Paramus, New Jersey

Pendleton, Oregon

Petaluna, California

Philadelphia, Pennsylvania

Pocatello, Idaho

Port Angeles, Washington

Portland, Oregon

Progress, Oregon

Rainier, Washington

Reedsport, Oregon

Rice Lake, Wisconsin

Riddle, Oregon

Ridgefield, Washington

Roseburg, Oregon

Rupert, Idaho

Salem, Oregon

Salt Lake City, Utah

San Antonio, Texas

San Francisco, California

Scappoose, Oregon

Seattle, Washington

Sherwood, oregon

Sisters, Oregon

South Holland, Illinois 1,886.15

Spokane, Washington

Sparks, Nevada

Springfield, Oregon

Stevenson, Washington

Sweet Home, Oregon

Tacoma, Washington

Tangent, Oregon

Tennessee NoS

The Dalles, Oregon

Tigard, Oregon

Tualatin, Oregon

Twin Falls, Idaho

Umpqua, Oregon

Union Gap, Washington

Urbandale, Iowa

Vancouver, Washington

Vernon, Kansas
7.52
98.37
0.96
0.06
3.21
0.22
22.22
12.84
1.55
3.29
8.05
0.12

$35,356.87$

14.88

0.07

1.60

0.23

40.50

16.59

204.30

1.72

259.10

50.93

4.52

111.02

6.75

47.59

40.13

10.14

33.47

2.21

953.32

0.24

3.75

226.29

77.44

9.11

$1,108.78$

193.22

23.11

32.30

0.07

6.30

3.56

$2,777.94$

13.69
0.01

0.16

0.00

0.00

0.01

0.00

0.04

0.02

0.00

0.01

0.01

0.00

58.30

0.02

0.00

0.00

0.00

0.07

0.03

0.34

0.00

0.43

0.08

0.01

0.18

0.01

0.08

0.07

0.02

3.11

0.06

0.00

1.57

0.00

0.01

0.37

0.13

0.02

1.83

0.32

0.04

0.05

0.00

0.01

0.01

4.58

0.02
0.02

40.07

0.00

0.00

0.01

0.00

36.83

0.03

1.25

96.76

2.77

0.00

78.50

0.03

0.00

0.00

0.36

0.09

0.17

0.45

0.59

0.58

100.00

1.66

89.34

0.01

0.48

0.09

0.02

61.98

0.34

100.00

2.12

0.00

0.01

2.27

0.17

100.00

2.46

0.43

0.05

11.12

0.00

0.06

100.00

27.84

100.00 
Containerized (continued)

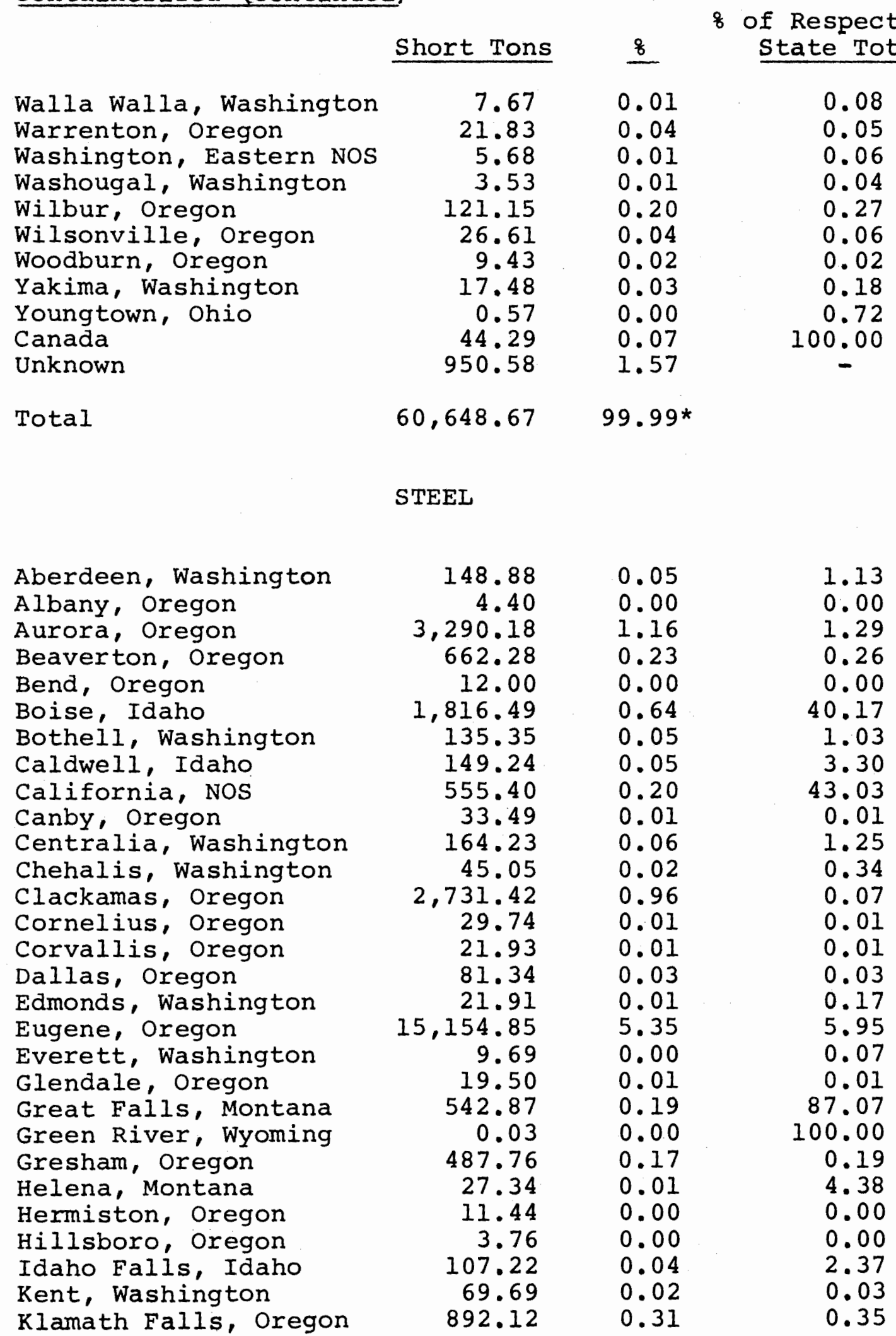

* Total does not sum to $100 \%$ due to rounding. 
Steel (continued)

Shor

Lebanon, Oregon

Long Beach, California

Longview, Washington

Mabton, Washington

McMinnville, oregon

Medford, Oregon

Milwaukie, Oregon

Missoula, Montana

Moses Lake, Washington

Nampa, Idaho

New York, NOS

North Bend, Oregon

Nyssa, Oregon

Oakland, California

Olympia, Washington

Oregon, All Other Cities

Oregon City, Oregon

Ostrander, Washington

Pasco, Washington

Payette, Idaho

Pomeroy, Washington

Port Westward, Oregon

Portland, oregon

Provo, Utah

Renton, Washington

Roseburg, Oregon

Salem, Oregon

$216,774.46$

136.50

44.75

$1,249.91$

$7,558.92$

Salt Lake City, Utah

21.59

San Francisco, California

San Jose, California

San Mateo, California

Santa Paula, California

Scappoose, Oregon

Seattle, Washington

Sherwood, Oregon

South Holland, Illinois

Spokane, Washington

Sunnyside, Washingtion

Tacoma, Washington

Tigard, Oregon

Tualatin, oregon

Twin Falis, Idaho

Vancouver, Washington

Walla Walla, Washington

Washington, Eastern NOS

Washougal, Washington

\section{$\frac{8}{8}$}

0.02

0.07

0.24

0.02

0.01

0.08

0.07

0.02

0.01

0.13

0.01

0.40

0.00

0.09

0.00

0.00

0.01

0.04

0.02

0.12

0.00

0.09

76.47

0.05

0.02

0.44

2. 67

0.01

0.03

0.02

0.01

0.04

0.33

0.71

0.01

0.00

0.28

0.04

0.10

0.94

0.08

0.61

0.54

0.05

0.02

2.25
\& of Respective State Total

0.02

15.66

5.27

0.50

0.02

0.09

0.08

8.55

0.17

8.19

100.00

0.45

0.00

19.58

0.01

0.00

0.01

0.90

0.33

7.69

0.09

0.10

85.07

86.34

0.34

0.49

2.97

13.66

6.04

5.02

2.83

7.84

0.36

15.41

0.01

100.00

6.04

0.92

2.15

1.04

0.08

38.28

11.58

1.04

0.46

48.61 
Steel (continued)

Short Tons 8

Yakima, washington

Canada

Unknown

Total

$\begin{array}{rr}214.40 & 0.08 \\ 31.61 & 0.01 \\ 8,878.67 & 3.13\end{array}$

$283,469.68$

99. 99*
8 of Respective State Total

1.63

100.00

$-$

\section{AUTOMOBILES}

$\begin{array}{lrrr}\text { Battle Ground, Washington } & 174.82 & 0.48 & 21.04 \\ \text { Nyssa, Oregon } & 2.49 & 0.01 & 0.01 \\ \text { Portland, Oregon } & 34,382.24 & 93.98 & 96.31 \\ \text { Seattle, Washington } & 656.09 & 1.79 & 78.96 \\ \text { Tigard, Oregon } & 1,315.42 & 3.60 & 3.68 \\ \text { Unknown } & 55.12 & 0.15 & - \\ & & & \\ \text { Total } & 36,586.18 & 100.01 * & -\end{array}$

BREAKBULK

Aberdeen, Washington

Agate Beach, Oregon

Albany, Oregon

Alsip, Illinois

Amity, oregon

Arkansas, NOS

Astoria, oregon

Athena, Oregon

Beaverton, Oregon

Battle Ground, Washington

Bend, Oregon

Billings, Montana

Boise, Idaho

Bozeman, Montana

Burlingame, California

Burns, Oregon

Caldwell, Idaho

California, Nos

Camas, Washington

Canby, Oregon

Carlton, Oregon

Centralia, washington

Chehalis, Washington

$\begin{array}{rrr}101.51 & 0.11 & 0.84 \\ 6.54 & 0.01 & 0.01 \\ 2,798.81 & 3.00 & 3.76 \\ 1.66 & 0.00 & 1.64 \\ 11.71 & 0.01 & 0.02 \\ 1.99 & 0.00 & 100.00 \\ 259.96 & 0.28 & 0.35 \\ 70.48 & 0.08 & 0.09 \\ 519.57 & 0.56 & 0.70 \\ 233.42 & 0.25 & 1.92 \\ 29.96 & 0.03 & 0.04 \\ 77.50 & 0.08 & 28.10 \\ 834.69 & 0.89 & 44.24 \\ 43.17 & 0.05 & 15.65 \\ 0.10 & 0.00 & 0.02 \\ 33.21 & 0.04 & 0.04 \\ 189.84 & 0.20 & 10.06 \\ 74.85 & 0.08 & 17.30 \\ 52.88 & 0.06 & 0.44 \\ 381.11 & 0.41 & 0.51 \\ 6.36 & 0.01 & 0.01 \\ 84.74 & 0.09 & 0.70 \\ 40.33 & 0.04 & 0.33\end{array}$

* Total does not sum to 1008 due to rounding. 
Breakbulk (continued)

\begin{tabular}{|c|c|c|c|}
\hline & Short Tons & 8 & $\begin{array}{l}\text { of Respective } \\
\text { State Total }\end{array}$ \\
\hline Chicago, Illinois & 16.33 & 0.02 & 16.14 \\
\hline clackamas, Oregon & 506.36 & 0.54 & 0.68 \\
\hline Clatskanie, oregon & 8.01 & 0.01 & 0.01 \\
\hline Cleveland, Ohio & 119.56 & 0.13 & 90.51 \\
\hline Coos Bay, Oregon & 55.96 & 0.06 & 0.08 \\
\hline Corvallis, Oregon & 11.58 & 0.01 & 0.02 \\
\hline Dallas, Oregon & 33.07 & 0.04 & 0.04 \\
\hline Dallas, Texas & 2.01 & 0.00 & 2.83 \\
\hline Denver, Colorado & 4.59 & 0.00 & 100.00 \\
\hline Donald, Oregon & 9.15 & 0.01 & 0.01 \\
\hline Downey, California & 10.10 & 0.01 & 2.33 \\
\hline Dundee, Oregon & 48.72 & 0.05 & 0.07 \\
\hline Eugene, Oregon & 961.10 & 1.03 & 1.29 \\
\hline Eureka, Utah & 16.66 & 0.02 & 6.97 \\
\hline Everett, Washington & 25.00 & 0.03 & 0.21 \\
\hline Forest Grove, Oregon & 539.50 & 0.58 & 0.72 \\
\hline Franklin Park, Ilinois & 18.26 & 0.02 & 18.05 \\
\hline Gaston, Oregon & 26.53 & 0.03 & 0.04 \\
\hline Gladstone, Oregon & 2.04 & 0.00 & 0.00 \\
\hline Goldendale, Washington & 578.39 & 0.62 & 4.76 \\
\hline Grants Pass, Oregon & 11.80 & 0.01 & 0.02 \\
\hline Great Falls, Montana & 132.91 & 0.14 & 48.19 \\
\hline Gresham, Oregon & 34.71 & 0.04 & 0.05 \\
\hline Harrisburg, Oregon & 307.56 & 0.33 & 0.41 \\
\hline Hermiston, Oregon & 24.55 & 0.03 & 0.03 \\
\hline Hillsboro, Oregon & 82.42 & 0.09 & 0.11 \\
\hline Hoquiam, Washington & 8.13 & 0.01 & 0.01 \\
\hline Hubbard, Oregon & 6.88 & 0.01 & 0.01 \\
\hline Idaho, Northeastern NOS & 172.98 & 0.19 & 9.17 \\
\hline Idaho Falls, Idaho & 159.46 & 0.17 & 8.45 \\
\hline IlIinois NOS & 0.25 & 0.00 & 0.25 \\
\hline Junction City, Oregon & 1.22 & 0.00 & 0.00 \\
\hline Kalama, Washington, & 3.71 & 0.00 & 0.03 \\
\hline Kalispell, Montanạ & 1.22 & 0.00 & 0.44 \\
\hline Kennewick, Washington & 2.05 & 0.00 & 0.02 \\
\hline Kent, Washington & 1.85 & 0.00 & 0.02 \\
\hline Klamath Falls, Oregon & 290.07 & 0.31 & 0.39 \\
\hline La Grande, Oregon & 18.84 & 0.02 & 0.03 \\
\hline Lake Grove, Oregon & 0.11 & 0.00 & 0.00 \\
\hline Lake Oswego, Oregon & 118.90 & 0.13 & 0.16 \\
\hline Lebanon, Oregon & 60.91 & 0.07 & 0.08 \\
\hline Lewiston, Idaho & 7.22 & 0.01 & 0.38 \\
\hline Lincolnwood, Illinois & 0.83 & 0.00 & 0.82 \\
\hline Longview, Washington & $1,420.54$ & 1.52 & 11.70 \\
\hline Los Angeles, California & 137.28 & 0.15 & 31.72 \\
\hline Louisiana NOS & 38.77 & 0.04 & 100.00 \\
\hline Mabton, Washington & 5.85 & 0.01 & 0.05 \\
\hline
\end{tabular}


Breakbulk (continued)

\section{$8 \quad$ State Total}

Maryland NOS

McMinnville, Oregon

Mead, Washington

Medford, oregon

Michigan, NOS

Milwaukee, Wisconsin

Milwaukie, Oregon

Minneapolis, Minnesota

Minnesota NoS

Montana NOS

Moxee City, Washington

Nampa, Idaho

New York, New York

Newberg, Oregon

Newport, Oregon

North Bend, Oregon

Nyssa, Oregon

Oakland, Oregon

Ogden, Utah

Ohio NOS

Omaha, Nebraska

Ontario, Oregon

Oregon, All other Cities

Oregon City, Oregon

Palmer, Alaska

Pendleton, oregon

Pocatello, Idaho

Portland, Oregon

Progress, Oregon

Prosser, Washington

Providence, Rhode Island

Pullman, Washington

Rainier, Washington

Redding, California

Redmond, Oregon

Reno, Nevada

Reedsport, Oregon

Richland, Washington

Roseburg, Oregon

Rupert, Idaho

Salem, Oregon

Salt Lake City, Utah

San Rafeal, California

Santa Paula, California

Scappoose, Oregon

Seattle, Washington

Sherwood, Oregon

Silverton, Oregon

\begin{tabular}{|c|c|c|}
\hline Short Tons & 8 & State Total \\
\hline 112.41 & 012 & \\
\hline $112 \cdot 41$ & 0.12 & 100.00 \\
\hline 109.13 & 0.12 & 0.15 \\
\hline 6.68 & 0.01 & 0.05 \\
\hline 323.63 & 0.35 & 0.43 \\
\hline 1.77 & 0.00 & 100.00 \\
\hline 1.10 & 0.00 & 100.00 \\
\hline 243.72 & 0.20 & 0.33 \\
\hline 0.69 & 0.00 & 1.83 \\
\hline 36.93 & 0.04 & 98.17 \\
\hline 21.00 & 0.02 & 7.61 \\
\hline 5.85 & 0.01 & 0.05 \\
\hline 47.61 & 0.15 & 2.52 \\
\hline 0.43 & 0.00 & 100.00 \\
\hline 1.13 & 0.00 & 0.00 \\
\hline 236.00 & 0.25 & 0.32 \\
\hline 1.41 & 0.00 & 0.00 \\
\hline 4.09 & 0.00 & 0.01 \\
\hline 27.67 & 0.03 & 0.04 \\
\hline 6.05 & 0.01 & 2.53 \\
\hline 12.53 & 0.01 & 9.49 \\
\hline 243.11 & 0.26 & 100.00 \\
\hline 95.00 & 0.10 & 0.13 \\
\hline 51.99 & 0.06 & 0.07 \\
\hline 25.74 & 0.03 & 0.03 \\
\hline 14.00 & 0.02 & 100.00 \\
\hline 90.81 & 0.10 & 0.12 \\
\hline 5.25 & 0.10 & 0.03 \\
\hline $60,211.74$ & 64.56 & 80.81 \\
\hline 20.63 & 0.02 & 0.03 \\
\hline 1.79 & 0.00 & 0.01 \\
\hline 0.01 & 0.00 & 100.00 \\
\hline 6.40 & 0.01 & 0.05 \\
\hline 53.05 & 0.06 & 0.04 \\
\hline 0.07 & 0.00 & 0.02 \\
\hline 77.35 & 0.08 & 0.10 \\
\hline $1,015.54$ & 1.09 & 13.22 \\
\hline 3.16 & 0.00 & 0.00 \\
\hline 2.15 & 0.00 & 0.02 \\
\hline 61.36 & 0.07 & 0.08 \\
\hline 0.99 & 0.00 & 0.05 \\
\hline $2,615,31$ & 2.80 & 3.51 \\
\hline 216.36 & 0.23 & 90.50 \\
\hline 98.97 & 0.11 & 22.87 \\
\hline 98.72 & 0.11 & 22.81 \\
\hline 25.07 & 0.03 & 0.03 \\
\hline 550.33 & 0.59 & 4.53 \\
\hline 56.44 & 0.06 & 0.08 \\
\hline 11.37 & 0.01 & 0.02 \\
\hline
\end{tabular}


Breakbulk (continued)

Short Tons

South Dakota NOS

South Holland, Illinois

Spokane, Washington

Sparks, Nevada

Springfield, Oregon

Stayton, Oregon

Stevenson, Washington

St. Paul, Oregon

Stimson, oregon

Stockton, California

Sunnyside, Washington

Sweet Home, Oregon

Tacoma, Washington

Tangent, Oregon

Temple, Texas

Tennessee NOS

The Dalles, oregon

Tigard, oregon

Tillamook, Oregon

Toledo, Oregon

Toppenish, Washington

Tualatin, Oregon

Twin Falls, Idaho

Umpqua, Oregon

Union Gap, Washington

Vancouver, Washington

Vernon, Kansas

Waco, Texas

Walla Walla, Washington

Washington, Eastern NOS

Washougal, Washington

White City, Oregon

Willamina, Oregon

Wilbur, Oregon

Woodenville, Washington

Yachats, Oregon

Yakima, Washington

Canada

Unknown

Total

$7,191.10$
客

2.92
63.85

63.85

124.04

371.37

14.22

314.19

0.16

1.38

2.41

12.65

3.78

1.16

51.13

160.52

5.93

9.04

$2,060.97$

128.36

132.81

57.34

561.44

34.80

468.51

0.47

1.45

1.65

62.97

12.32

217.64

479.75

0.02

17.64

6.50

19.60

9.83

298.90

30.95

$1,586.01$

$93,270.60$ of of Respective

State Total

100.00

63.11

1.02

26.78

0.02

0.42

0.00

0.00

0.00

2.92

0.03

0.00

0.42

0.22

8.36

100.00

2.77

0.17

0.18

0.08

4.62

0.05

24.83

0.00

0.01

59.21

100.00

88.80

0.10

1.79

3.94

0.00

0.02

0.01

0.16

0.01

2.46

100.00

0.03

1.70

100.00 


\section{APPENDIX D}

PORT OF PORTIAND 1973 EXPORTERS AND IMPORTERS

(100 tons or more in any quarter)

\section{EXPORTERS}

Acker Export Iumber Co.

$1220 \mathrm{~S} . \mathrm{W}$. Morrison

Portland, Oregon 97205

Acme Trading and Supply Co.

4322 N.W. Yeon

Portland, oregon 97210

Active Equipment Co., Inc.

2765 N.W. Nicolai

Portland, Oregon 97210

Agripac Inc.

P.O. Box 5346

Salem, Oregon 97304

Alcoa International

5201 S.W. Westgate Dr.

Portland, Oregon 97221

Alder Creek Lumber Co.

Rt. I Box 530

Burlington, Oregon 97231

Associated Meat Packers

P.O. Box 17195

Portland, Oregon 97203

Berger and Plate Co. of Oregon Route 2, Box 48

Harrisburg, Oregon 97446

Blue Line Exchange, Inc. Box 37

Portland, Oregon 97043
Boise-Cascade Corp. 1600 S.W. 4th Ave.

Portland, Oregon 97201

Caffall Bros. Forest Products

$5405 \mathrm{~N}$. Lagoon

Portland, Oregon 97217

Cahen Trading Co.

P.O. Box 17006

Portland, Oregon 97214

Calbag Metals

2495 N.W. Nicolai

Portland, Oregon 97210

Cargill, Inc.

1000 World Trade BIdg.

333 S.W. Oak

Portland, Oregon 97204

Coast Packing Co., Inc. P.O. Box 11203

Portland, Oregon 97211

Columbia Wool scouring $2030 \mathrm{~N}$. Columbia Blvd. Portland, Oregon 97217

Consolidated Fibers $1601 \mathrm{~N}$. Columbia Blvd. Portland, Oregon 97217

Dant and RusselI Inc. 1221 S.W. Yamhill Portland, Oregon 97205 
D \& M Products, Inc.

11320 N.E. Marx

Portland, Oregon 97220

Dow Chemical Co.

305 Crenshaw Blva.

Torrance, California 90503

Empire Metals Co.

1304 N.W. Johnson

Portland, Oregon 97209

General Mills

2828 S.W. Corbett

Portland, Oregon 97201

Gold Rey Forest Products 3500 S.W. Cedar Hills Blvd.

Beaverton, Oregon 97005

Great Western Malting Co.

Foot of W. IIth

Vancouver, Washington 98660

Halton Tractor Co.

4421 N.E. Columbia Blvd.

Portland, Oregon 97218

Hercules, Inc.

3366 N.W. Yeon

Portland, Oregon 97210

Independent Paper Stock Co.

$1315 \mathrm{~N} . \mathrm{W}$. Overton

Portland, Oregon 97209

International Paper Co. Box 579

Longview, Washington 98632

Kanematsu Gosho U.S.A.

707 S.W. Washington

Portland, Oregon 97205

Kasho, Inc.

1 California

San Francisco, California 94111
Kerr Grain

First National Bank Tower 1300 S.W. 5th Ave.

Portland, Oregon 97201

Linnton Plywood Assn. 10504 N.W. St. Helens Rd. Portland, Oregon 97231

$M \& C$ Lumber Products Inc. 9020 N. Bradford

Portland, Oregon 97203

McCall Oil Co.

1935 S.E. Powell BIvd.

Portland, Oregon 97202

McCormick \& Baxter Co. $6900 \mathrm{~N}$. Edgewater

Portland, Oregon 97203

Mindel, David \& Sons Inc. 3520 E. Vernon Ave.

Los Angeles, California 90058

Nez Perce Rochdale Co. Nez Perce, Idaho 83543

Normarc, Inc.

P.O. Box 238

Tangent, Oregon 97389

Northwest Organic Products Rt. 1

Aurora, Oregon 97002

Northwest Paper Fibers

2625-A N.W. Industrial

Portland, Oregon 97210

oregon commodities

1007 Corbett Blva. 430 S.W. Morrison

Portland, Oregon 97204

Pacific Hide and Fur Depot 8 - 21st Ave. S. Nampa, Idaho 83651 
Patrick Lumber Co.

825 Terminal Sales Bldg.

1220 S.W. Morrison

Portland, Oregon 97205

Peavey Company

1100 World Trade Bldg.

333 S.W. Oak

Portland, Oregon 97204

Peerless Trailer \& Truck

18205 S.W. Boones Ferry Rd.

Tigard, Oregon 97223

Pope \& Talbot Inc.

1700 S.W. 4 th Ave.

Portland, Oregon 97201

Portland Rendering Co.

P.O. Box 17201

Portland, Oregon 97217

Publishers Paper Co.

419 Main

Oregon City, oregon 97045
Ross Equipment Inc. 9522 N.E. Sandy Blvd. Portland, Oregon 97220

Southwest Hide Company 309 S. 25th

Boise, Idaho 83706

Teledyne Service Co. 1605 N.W. Everett Portland, Oregon 97209

Terminal Flour Mills Municipal Terminal \#4

Portland, Oregon 97202

U.S. Plywood

1122 N.E. $122 \mathrm{nd}$

Portland, Oregon 97229

West Coast Orient Co. $5403 \mathrm{~N}$. Lagoon Ave. Portland, Oregon 97217

Wilbur-Ellis CO. P.O. Box 8838

Portland, Oregon

97208

IMPORTERS

Airco Welding Products 1325 N.W. Kearney

Portland, Oregon 97209

Alaska Copper \& Brass 2440 S.E. Raymond

Portland, Oregon 97201

Alaska Steel Company

2750 S.W. Moody

Portland, Oregon 97201

Allied Chemical Corp

1410 S.W. Marlow

Portland, Oregon 97225

American Honda Motor Co., Inc. 6215 N.E. 92nd Dr.

Portland, Oregon 97220
American Steel, Inc. 4033 N.W. Yeon

Portland, Oregon 97210

American Steel \& Supply

888 Garfield

Eugene, Oregon 97402

Atlas Iron Works

4600 N.E. 138 th

Portland, Oregon 97230

Balfour Guthrie Trade Div. 731 S.W. Oak

Portland, Oregon 97204

Barnes, R.A., Inc. 2000 Columbia Way

Vancouver, Washington 98661 
Beall Pipe \& Tank Co. 12005 N. Burgard Rd.

Portland, Oregon 97203

George Boldt \& Co.

8750 S.W. Bohmann Parkway

Portland, Oregon 97223

Bonneville Power Admin. 1002 N.E. Holladay

Portland, Oregon 97232

Boyd Coffee Company

19730 N.E. Sandy BIvd.

Portland, Oregon 97230

Bridgstone Tire

2210 N.E. Riverside Way

Portland, Oregon 97211

British Leyland

4860 S.W. Scholls Ferry Rd.

Portland, Oregon 97225

British Motor Company

1638 W. Burnside

Portland, Oregon 97209

Brumley Donaldson

Sylvan BIdg., 2035 S.W. 58th

Portland, Oregon 97221

Buick Motor Division

P.O. Box 25300

Portland, Oregon 97229

Burns Bros. Imports

81 S.E. Yamhill

Portland, Oregon 97204

CaI-Auto, Inc.

2005 N.E. Union

Portland, Oregon 97212

Cal Roof Wholesale

110 S.E. Taylor

Portland, Oregon 97214

Cascade Corporation

5319 S.W. Westgate Dr. Portland, Oregon 97221
Chin's Import-Export

1633 N.E. 42 nd

Portland, Oregon 97213

Columbia Warehouse

$6710 \mathrm{~N}$. Catlin

Portland, Oregon 97203

Consolidated supply

$2300 \mathrm{~N} . \mathrm{W} .26 \mathrm{th}$

Portland, Oregon 97210

Continental Parts

Commonwealth Building

421 S.W. 6th Ave.

Portland, Oregon

97204

Convoy Company

3900 N.W. Yeon

Portland, Oregon 97210

Copeland Wholesale

119 S.E. Main

Portland, Oregon 97214

Cord Agency

P.O. Box 19063

Portland, Oregon 97219

David Cordage Co.

677 N. Tillamook

Portland, Oregon 97227

John Deere

2100 N.E. l81st Ave.

Portland, Oregon 97230

W.C. Delbrueck \& Co.

2170 N.W. Raleigh

Portland, Oregon 97210

Del Monte Corp.

1425 N.E. Irving

Portland, Oregon 97227

Elixir Industry

P.O. Box 203

Aurora, Oregon 97002 
Empire Building Material 9255 N.E. Halsey

Portland, Oregon 97220

Familian N.W. Inc. 2121 N. Columbia Blva. Portland, Oregon 97217

Farmers Union Central Cenex 80 S.E. Taylor Portland, Oregon 97214

Far West Steel P.O. Box 632

Eugene, Oregon 97401

Ford Motor Co. $14880 \mathrm{S.W} .72 \mathrm{nd}$

Portland, Oregon 97223

Fort Hill Lumber 2041 S.W. 58 th

Portland, Oregon 97221

Fought \& Co., Inc. 14255 S.W. 72nd

Tigard, Oregon 97223

Fred Meyer, Inc. $3800 \mathrm{~S} . \mathrm{E} .22 \mathrm{nd}$

Portland, oregon 97202

Galvanizers Co. 2406 N.W. 30th

Portland, Oregon 97210

Gear Reducer Sales

Terminal Sales Bldg.

1220 S.W. Morrison

Portland, Oregon 97205

General Electric

Sales Division

2929 N.W. 29th

Portland, Oregon 97210

General Metalcraft, Inc. 4701 S.E. 24 th Ave. Portland, Oregon' 97202
Gilmore Steel Corp.

6161 N.W. 61st Ave.

Portland, Oregon 97203

Giusti, Al Wine

66 S.E. Morrison

Portland, Oregon 97214

Golby Bag Co.

815 N.W. 16th

Portland, Oregon 97209

Gray Company, Inc.

805 N.W. 14th

Portland, Oregon 97209

Green Transfer \& Storage 2425 N.W. 23 rd Place

Portland, Oregon 97210

Grinnel of Oregon

3240 N.W. 29 th

Portland, Oregon 97210

Hall Tool Co.

1724 S.E. Grand

Portland, Oregon 97214

Hearth Craft, Inc.

7945 N.E. Alberta

Portland, Oregon 97218

Hoffman Motors

375 Park Avenue

New York, N.Y 10022

Holland Bulb Co.

10420 S.E. 82nd

Portland, Oregon 97266

Industrial Export Co. Board of Trade Building 310 S.W. 4th Ave. Portland, Oregon 97204

Interstate Manufacturing 8319 S.E. Otty Ra. Portland, Oregon 97266 
Interstate Tractor

\& Equipment $\mathrm{Co}$.

2855 N.W. Front Avenue

Portland, Oregon 97210

Kaiser cement \& Gypsum Corp. 3510 S.W. Bond

Portland, Oregon 97201

Kay Sales

9800 S.E. Stark

Portland, Oregon 97216

La Grande Industrial Supply

2620 S.W. Ist

Portland, Oregon 97201

Lane Forging \& Supply

9140 S.W. 57 th

Portland, oregon 97219

Letts Industries, Inc.

2524 N.E. Riverside Way

Portland, Oregon 97211

Libby MaNeill \& Libby

200 South Michigan

Chicago, Illinois 60604

The Lunch Company, Inc. 6000 N.E. Union

Portland, Oregon 97211

Marcrest Pacific

24724 Wilmington Avenue

Wilmington, California 90745

Martin Marieta

P.O. Box 7711

The Dalles, Oregon 97058

Massey Ferguson

8303 N.E. Killingsworth

Portland, Oregon 97220

Master Fence Fittings

2020 N.E. 194th

Portland, Oregon 97230
Meier \& Frank

Att: Nealond Howard

621 S.W. 5th Ave.

Portland, Oregon 97204

Meyers Sales Co.

Coleman Bldg.

811 First

Seattle, Washington 98104

Michelin Tire Corp.

4240 N.W. Yeon

Portland, Oregon 97210

Mitsubishi International 205 Commonwealth Bldg.

421 S.W. 6th

Portland, Oregon 97204

M.J.B.

2801 N.W. Nela

Portland, Oregon 97210

Moore Dry Kiln Co.

P.O. Box 4208

Portland, Oregon 97208

Morris P. Kirk \& Sons

5909 N.W. 6lst

Portland, Oregon 97210

Ted Nelson Co.

14280 S.W. 72nd

Tigard, Oregon 97209

New York Merchandise

1900 N.W. 22nd

Portland, Oregon 97210

Nissan Motor Corp.

9575 S.W. Scholls Ferry Rd.

Portland, Oregon 97223

Norcrest China Co.

$55 \mathrm{~W}$. Burnside

Portland, Oregon 97209

Norpac Growers, Inc.

P.O. Box 203

Dundee, Oregon 97115 
Oregon Glass

2170 N.W. Raleigh

Portland, Oregon

97210

O.L.C.C.

9201 S.E. MCLoughlin BIVd.

Milwaukie, oregon 97222

Oregon Metallurgical Corp. P.O. Box 580

Albany, Oregon 97321

Oregon Metal Slithers, Inc. 2245 N.W. Suffolk

Portland, Oregon 97210

Pacific Carbide \& Alloy

N. Columbia BIvd. \& Hurst

Portland, Oregon 97203

Pacific Fence \& Wire

2235 S.E. 11th

Portland, Oregon 97214

Pacific Metal Co.

3400 S.W. Bond

Portland, Oregon 97201

Pacific Steel Warehouse 3865 N.W. St. Helens Rd. Portland, Oregon 97210

Pak-Well Paper Products 2517 Mailwell Drive Milwaukie, Oregon 97222

Peerless Pacific

$625 \mathrm{~N}$. Thompson

Portland, Oregon 97227

Perma Flora Import-Export 733 N.W. Everett

Portland, Oregon 97209

Pettibone Westrac

3103 N.W. St. Helens Rd.

Portland, Oregon 97210

Plumbers Supply Co. 3500 S.E. 22 nd Portland, Oregon 97202
Rope Rigging Loft

2355 N.W. 2Ist Place

Portland, Oregon 97210

Portland Wire \& Iron Works 4644 S.E. 17 th

Portland, Oregon 97214

Port Services Co.

9125 N. Bradford

Portland, Oregon 97203

Precon Products

$240 \mathrm{~W}$. Los Angeles

St. Simi Valley, Calif. 93065

Preferred Import Co.

1137 S.E. Union Ave.

Portland, Oregon 97214

San Jose Steel Co.

$723 \mathrm{~N}$. Tillamook

Portland, Oregon

97227

Schermerhoen Brothers

2336 N.W. 21 st

Portland, Oregon 97209

Spada Distributing

1137 S.E. 12th

Portland, Oregon 97214

Sprouse Reitz Co., Inc. 1411 S.W. Morrison

Portland, Oregon 97205

Standard Supply Co. 934 S.E. 6th

Portland, Oregon 97214

Standard Steel Warehouse 3441 N.W. Guam Portland, Oregon 97210

Stauffer Chemical Co. 4429 N. Suttle Road North Portland, Oregon 97217 
Steel Fabricators, Inc. 1353 S. Redland Rd. Oregon City, Oregon 97045

Steel Products Co. 4000 N.W. St. Helens Rd. Portland, Oregon 97210

Steel Products of oregon 4000 N.W. St. Helens Rd. Portland, Oregon 97210

Steel Specialties, Inc. $8520 \mathrm{~N}$. Kerby

Portland, Oregon 97217

Subaru Northwest, Inc. 809 N.E. Lombard

Portland, Oregon 97211

Town Concrete Pipe, Inc. 755 N.E. Columbia Blvd. Portland, Oregon 97211

Toyota

6111 N.E. 87 th

Portland, Oregon 97220

Tricon, Inc.

3311 Andover Park E

Seattle, Washington 98188

Tumac Lumber Co.

806 S.W. Broadway

Portland, Oregon 97205

Union Carbide Corp.

$11920 \mathrm{~N}$. Burgard Rd.

Portland, Oregon 97203

UNIQ Dist. Co., InC.

3435 S.E. 17 th

Portland, Oregon 97202

usco Service Co.

2734 S.E. Raymond

Portland, Oregon 97202

Valley Rolling Mills, Inc. 2025 Hyacinth N.E.

Salem, Oregon 97303
Viking Automatic Sprinkler 3245 N.W. Front

Portland, Oregon 97210

Viking Industries

7737 N.E. Killingsworth

Portland, Oregon 97218

Wade, R.M. , Co.

10025 S.W. Allen BIvd.

Beaverton, Oregon 97005

WESCO Sales

8301 N.E. Halsey

Portland, Oregon 97220

West Coast Wire Pope

\& Rigging, Inc.

2201 N.W. 20th

Portland, Oregon 97209

Western Import Co.

6635 N. Baltimore

Portland, Oregon 97203

Western Overhead Door

5511 S.E. 26 th

Portland, Oregon 97202

Wheelsport Dist.,

2053 N.W. Upshur

Portland, Oregon 97209

White Stag Manufacturing 5100 S.E. Harney Dr. Portland, Oregon 97222

Winter Wolff \& CO., Inc. 2035 S.W. 58 th

Portland, Oregon 97221

Woodburg \& Co. 5851 N. Lagoon Ave. Portland, Oregon 97217

Yokohama Tire Corp. $10603 \mathrm{~N}$. Lombard Portland, Oregon 97203

Zehrung Corp.

2201 N.W. 20 th Ave. Portland, Oregon 97209 
IMPORTERS AND EXPORTERS

Bingham Willamette

2800 N.W. Front

Portland, Oregon 97210

Centennial Mills

P.O. Box 3773

Portland, Oregon 97210

Chase Bag Co.

2550 N.W. Nicolai

Portland, Oregon 97210

Continental Can Co.

1618 S.W. 1st Ave.

Portland, Oregon 97201

Crown Zellerbach Corp.

1500 S.W. Ist Ave.

Portland, Oregon 97201

ESCO

2141 N.W. 25th Ave.

Portland, Oregon 97210

FMC Corp.

4350 N.W. Front

Portland, Oregon 97210

Friedman Bag Co., Inc. 1040 N.E. 44 th Ave.

Portland, Oregon 97213

Hyster Co.

2902 N.E. Clackamas

Portland, Oregon 97232

Nabisco

100 N.E. Columbia BIva.

Portland, Oregon 97211

Niedemeyer Martin Co.

1727 N.E. 11th Ave.

Portland, Oregon 97212
North Pacific Lumber Co. 1505 S.E. Gideon

Portland, Oregon 97202

Pacific Molasses Co. Municipal Terminal \#4

Portland, Oregon 97202

Pacific Supply Corp.

P.O. Box 3588

Portland, Oregon 97208

Portland Fish Co. 301 N.W. 3rd Ave. Portland, Oregon 97209

Reynolds Aluminum Supply 323 S.E. Division Place Portland, Oregon 97202

Rhodia/Chipman Chemical 6200 N.W. St. Helens Rd. Portland, Oregon 97210

Schnitzer Steel Products $3300 \mathrm{~N} . \mathrm{W}$. Yeon

Portland, Oregon 97210

Standard Steel and Tube Supply

2211 N.W. Front

Portland, Oregon 97209

Wagner Mining Equipment 4424 N.E. 158th Ave. Portland, Oregon 97230

Weyerhaeuser Co. 5350 S.W. 107th Ave. Beaverton, Oregon 97005

Zidell Explorations 3121 S.W. Moody Portland, Oregon 97201 


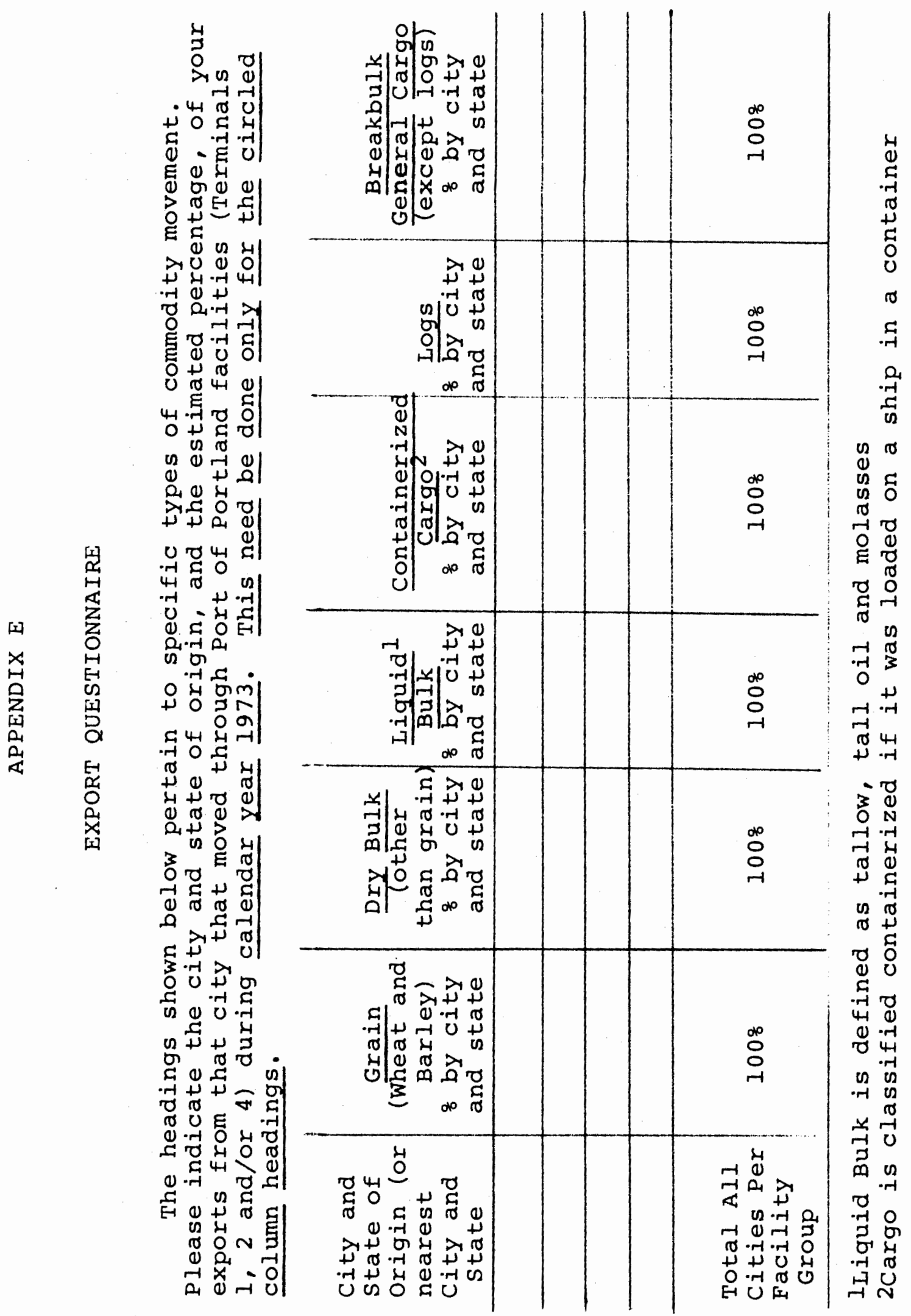




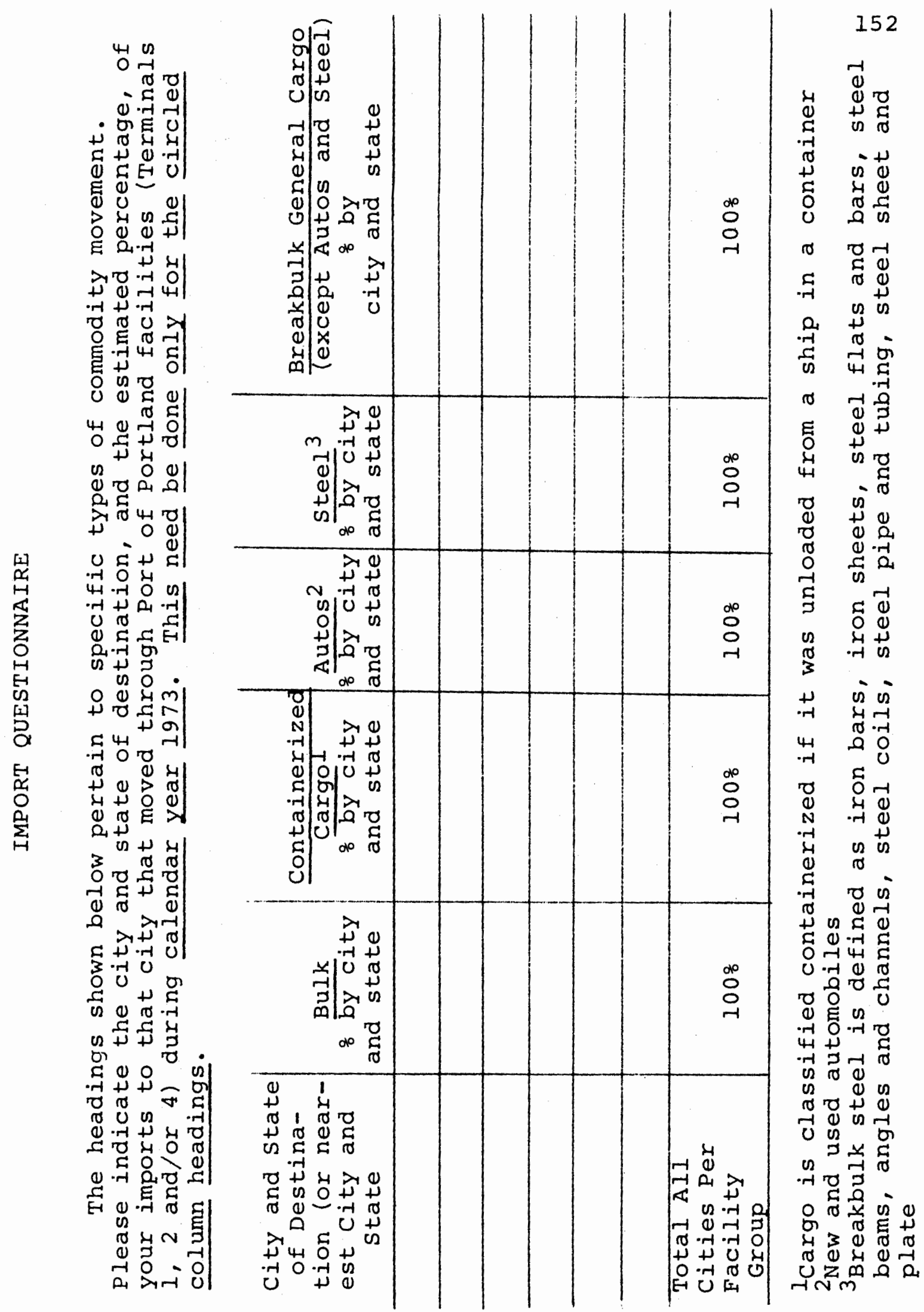




\title{
APPENDIX F
}

\author{
STATE ORIGINS OF EXPORTS FROM \\ PORT OF PORTLAND FACILITIES 1973 \\ (including sample results-excluding logs)
}

IIQUID BULK

Short Tons

Idaho

Montana

Oregon

Washington

Unknown

Total
GRAIN

Short Tons

Colorado

Idaho

Montana

North Dakota

Oregon

Washington

Unknown

Total

$164,199.91$

$114,939.93$

$544,827.70$

$98,519.95$

$344,819.79$

$377,671.34$

$21,651.84$

$1,666,630.46$

$\begin{array}{rr}708.42 & 3.05 \\ 882.81 & 3.79 \\ 17,479.88 & 75.14 \\ 3,060.66 & 13.16 \\ 1,131.08 & 4.86 \\ 23,262.85 & 100.00\end{array}$

昰

$$
\begin{array}{r}
9.85 \\
6.90 \\
32.69 \\
5.91 \\
20.69 \\
22.66 \\
1.30
\end{array}
$$

100.00

\section{DRY BULK}

Short Ions

Colorado

Idaho

Montana

North Dakota
$4,440.36$
2.51
$22,128.59$
12.51
$31,650.86$
17.91
$2,663.14$
1.51 
Dry Bulk (continued)

Oregon

Washington

Wyoming

Total
Short Tons

$$
46,113.29
$$

$19,573.83$

$50,280.33$

$176,860.40$

CONTA INERI ZED

Short Tons

Alabama

Arizona

Arkansas

California

Canada

Idaho

Illinois

Indiana

Iowa

Kansas

Michigan

Minnesota

Missouri

Montana

Nebraska

New Hampshire

New Jersey

Nevada

Oregon

Pennsylvania

Tennessee

Texas

Utah

Virginia

Washington

Washington, D.C.

Wisconsin

Wyoming

Unknown

Total

$\begin{array}{rr}2.45 & 0.00 \\ 447.49 & 0.16 \\ 487.74 & 0.17 \\ 209.12 & 0.17 \\ 80.27 & 0.03 \\ 12,463.69 & 4.33 \\ 25.99 & 0.01 \\ 5.50 & 0.00 \\ 40.03 & 0.01 \\ 19.05 & 0.01 \\ 3.77 & 0.00 \\ 24.25 & 0.01 \\ 0.95 & 0.00 \\ 1,270.93 & 0.44 \\ 116.64 & 0.04 \\ 507.50 & 0.18 \\ 20.86 & 0.01 \\ 68.81 & 0.02 \\ 190,116.47 & 65.97 \\ 33.12 & 0.01 \\ 159.89 & 0.06 \\ 175.47 & 0.06 \\ 137.54 & 0.05 \\ 124.92 & 0.04 \\ 58,516.01 & 20.30 \\ 15.50 & 0.01 \\ 38.18 & 0.01 \\ 1,201.67 & 0.42 \\ 21,858.13 & 7.58 \\ 288,171.94 & 100.00 \\ & \end{array}$


BREAKBULK

Arizona

Arkansas

California

Canada

Connecticut

Idaho

Illinois

Iowa

Louisiana

Maine

Michigan

Minnesota

Mississippi

Missouri

Montana

New Hampshire

New Jersey

Nevada

Ohio

Oregon

Pennsylvania

South Dakota

Texas

Utah

Washington

Wisconsin

Wyoming

Unknown
Short Tons 学

$\begin{array}{rr}3.93 & 0.00 \\ 46.21 & 0.01 \\ 893.92 & 0.24 \\ 133.99 & 0.24 \\ 1.32 & 0.00 \\ 8,410.17 & 2.22 \\ 140.48 & 0.04 \\ 20.98 & 0.01 \\ 1.50 & 0.00 \\ 0.02 & 0.00 \\ 29.77 & 0.01 \\ 11.27 & 0.00 \\ 46.21 & 0.01 \\ 5.62 & 0.00 \\ 1,705.81 & 0.45 \\ 161.98 & 0.04 \\ 10.31 & 0.00 \\ 221.62 & 0.06 \\ 2.25 & 0.00 \\ 292,864.36 & 77.29 \\ 198.93 & 0.05 \\ 185.50 & 0.05 \\ 128.65 & 0.03 \\ 2,930.69 & 0.77 \\ 57,981.92 & 15.30 \\ 4.70 & 0.00 \\ 6,461.04 & 1.71 \\ 6,331.85 & 1.67\end{array}$

ALI EXPORT FACILITY GROUPS

Short Tons
Alabama
Arizona
Arkansas
California
Canada
Colorado
Connecticut
Idaho
Illinois
Indiana
Iowa

$\begin{array}{rr}2.45 & 0.00 \\ 451.42 & 0.02 \\ 533.95 & 0.02 \\ 1.103 .04 & 0.04 \\ 214.26 & 0.01 \\ 168,640.27 & 6.66 \\ 1.32 & 0.00 \\ 158,650.80 & 6.26 \\ 166.47 & 0.01 \\ 5.50 & 0.00 \\ 61.01 & 0.00\end{array}$


Al1 Export Facility Groups (continued)

$\begin{array}{lrr}\text { Kansas } & 19.05 & 0.00 \\ \text { Louisiana } & 1.50 & 0.00 \\ \text { Maine } & 0.02 & 0.00 \\ \text { Michigan } & 33.54 & 0.00 \\ \text { Minnesota } & 35.52 & 0.00 \\ \text { Mississippi } & 46.21 & 0.00 \\ \text { Missouri } & 6.57 & 0.00 \\ \text { Montana } & 148.11 & 22.90 \\ \text { Nebraska } & 116.64 & 0.00 \\ \text { New Hampshire } & 669.48 & 0.03 \\ \text { New Jersey } & 31.17 & 0.00 \\ \text { Nevada } & 290.43 & 0.01 \\ \text { North Dakota } & 101,183.09 & 3.99 \\ \text { Ohio } & 2.25 & 0.00 \\ \text { Oregon } & 891,393.79 & 35.18 \\ \text { Pennsylvania } & 232.05 & 0.01 \\ \text { South Dakota } & 185.50 & 0.01 \\ \text { Tennessee } & 159.89 & 0.01 \\ \text { Texas } & 304.12 & 0.01 \\ \text { Utah } & 3,068.23 & 0.12 \\ \text { Virginia } & 124.92 & 0.00 \\ \text { Washington } & 516,803.76 & 20.40 \\ \text { Washington, D.C. } & 15.50 & 0.00 \\ \text { Wisconsin } & 42.88 & 0.00 \\ \text { Wyoming } & 57,943.04 & 2.29 \\ \text { Unknown } & 50,972.90 & 2.01 \\ & & \\ \text { Total } & 2,533,860.65 & 99.99 * \\ \text { Total } & & \end{array}$

* Total does not sum to 1008 due to rounding. 


\section{APPENDIX G}

\section{STATE DESTINATIONS OF IMPORTS THROUGH PORT OF PORTLAND FACILITIES 1973 (including sample results)}

BULK

Short Tons

Oregon

Washington

Unknown

Total

California

Canada

Idaho

Illinois

Montana

New York

Oregon

Utah

Washington

Wyoming

Unknown

Total
$176,172.14$

$19,204.32$

477.05

$195,853.51$

STEEL

Short Tons

$1,506.00$

157.94

$6,824.46$

8.85

813.02

23.08

$242,622.46$

185.71

$22,449.83$

0.03

$8,878.67$

$283,469.68$
8

89.95

9.81

0.24

100.00

AUTOMOBILES

Short Tons

8

Alaska

$2,774.81$

7.58

31.36

$\underline{8}$

0.53

0.06

2.41

0.00

0.29

0.01

85.58

0.07

7.92

0.00

3.13

100.00 
Automobiles (continued)

Short Tons

Montana

Oregon

Utah

Washington

Unknown

Total
20.91

$12,220.50$

75.72

$17,068.48$

55.12

$36,586.18$
\&

0.06

33.40

0.21

46.65

0.15

100.00

CONTAINERIZED

Short Tons

Alaska

California

Canada

Idaho

Illinois

Iowa

Kansas

Michigan

Minnesota

Montana

Nevada

New Jersey

New York

Ohio

Oregon

Pennsylvania

Tennessee

Texas

Utah

Washington

Wisconsin

Wyoming

Unknown

Total

$\begin{array}{rr}125.51 & 0.21 \\ 1,323.90 & 2.18 \\ 44.29 & 0.07 \\ 375.67 & 0.62 \\ 7,488.07 & 12.35 \\ 3.56 & 0.01 \\ 13.69 & 0.02 \\ 226.60 & 0.37 \\ 14.43 & 0.02 \\ 81.22 & 0.13 \\ 2.21 & 0.00 \\ 60.33 & 0.10 \\ 3,600.19 & 5.94 \\ 78.99 & 0.13 \\ 33,387.41 & 55.05 \\ 3.40 & 0.01 \\ 9.11 & 0.02 \\ 1,742.59 & 2.87 \\ 50.93 & 0.08 \\ 10,989.72 & 18.12 \\ 63.86 & 0.11 \\ 12.41 & 0.02 \\ 950.58 & 1.57 \\ & \\ 60,648.67 & 100.00\end{array}$

BREAKBULK

Short Tons

0.03 
Breakbulk (continued)

Short Tons

California

$1,293.91$

1.39

Canada

30.95

0.03

Colorado

4.59

Idaho

Illinois

$2,740.80$

0.00

2.94

Kansas

$2,793.18$

2.99

Louisiana

1.65

38.77

Maryland

Michigan

112.41

7.53

37.62

275.80

243.11

Montana

Nebraska

$1,458.40$

Nevada

$2,024.10$

132.09

Ohio

$63,978.10$

Oregon

Rhode Island

2.92

0.00

0.04

0.12

0.01

0.04

0.30

0.26

1. 56

2.17

0.14

68.60

0.00

0.00

0.01

0.53

491.74

0.26

Utah

239.07

16.87

0.00

1.70

Unknown

1.10

$1,586.01$

$99.99 *$

ALL IMPORT FACILITY GROUPS

Total

$93,270.60$

Short Tons

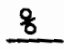

Alaska

Arkansas

California

$2,932.01$

1.99

0.44

0.00

$4,123.81$

0.62

233.18

0.03

Canada

Colorado

4.59

31.36

Idaho

$14,280.21$

0.00

0.00

2.13

I. 54

0.00

3.56

0.00

38.77

0.01

112.41

0.02

Maryland

* Total does not sum to $100 \%$ due to rounding. 
All Import Facility Groups (continued)

Short Tons

$\underline{8}$

$\begin{array}{lrr}\text { Michigan } & 234.13 & 0.03 \\ \text { Minnesota } & 52.05 & 0.01 \\ \text { Montana } & 1,190.95 & 0.18 \\ \text { Nebraska } & 243.11 & 0.04 \\ \text { Nevada } & 1,460.61 & 0.22 \\ \text { New Jersey } & 60.33 & 0.01 \\ \text { New York } & 5,647.37 & 0.84 \\ \text { Ohio } & 211.08 & 0.03 \\ \text { Oregon } & 528,380.61 & 78.88 \\ \text { Pennsylvania } & 3.40 & 0.00 \\ \text { Rhode Island } & 0.01 & 0.00 \\ \text { South Dakota } & 2.92 & 0.00 \\ \text { Tennessee } & 18.15 & 0.00 \\ \text { Texas } & 2,234.33 & 0.33 \\ \text { Utah } & 551.43 & 0.08 \\ \text { Washington } & 85,446.37 & 12.76 \\ \text { Wisconsin } & 64.96 & 0.01 \\ \text { Wyoming } & 12.44 & 0.00 \\ \text { Unknown } & 11,947.43 & 1.78 \\ \text { Total } & & \\ & 669,828.69 & 99.99 * \\ \text { * Total does not sum to I008 due to rounding. }\end{array}$

